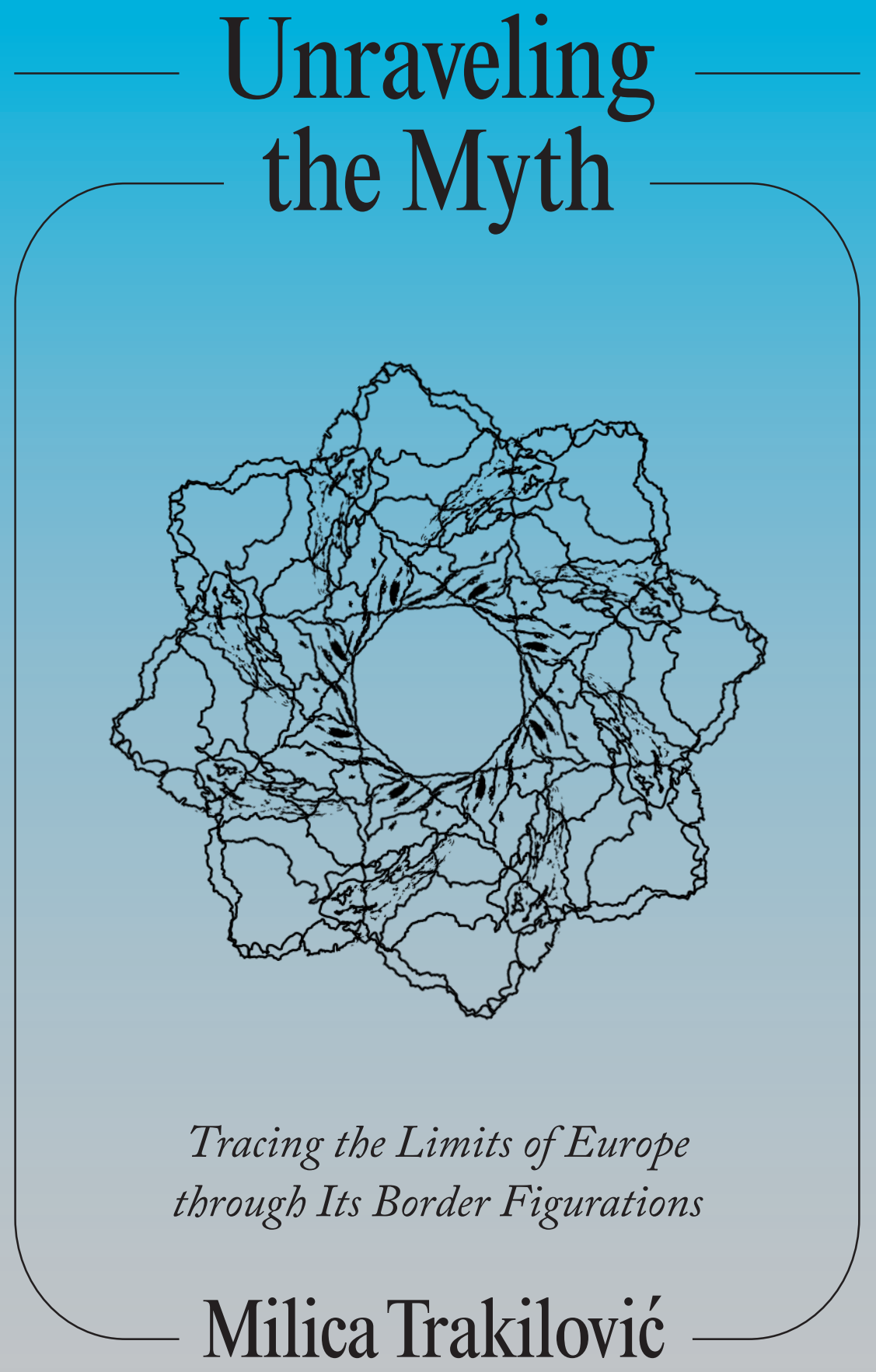





\title{
Unraveling the Myth
}

Tracing the Limits of Europe through Its Border Figurations

\author{
De Mythe Ontrafelen \\ De Grenzen van Europa Traceren \\ via diens Grens Figuraties \\ (met een samenvatting in het Nederlands)
}

PROEFSCHRIFT

Ter verkrijging van de graad van doctor aan de Universiteit Utrecht op gezag van de rector magnificus,

PROF.DR. H.R.B.M. KuMmELING,

ingevolge het besluit van het college voor promoties

in het openbaar te verdedigen op

VRIJDAG I 6 OKTOBER 2020

DES OCHTENDS TE IO.3O UUR

door

\section{Milica Trakilović}

geboren op ro oktober 1986

te Tuzla, Bosnië en Herzegovina 
Promotoren:

PROF. DR. R.L. BUIKEMA

PROF. DR. S. PonZanesi 


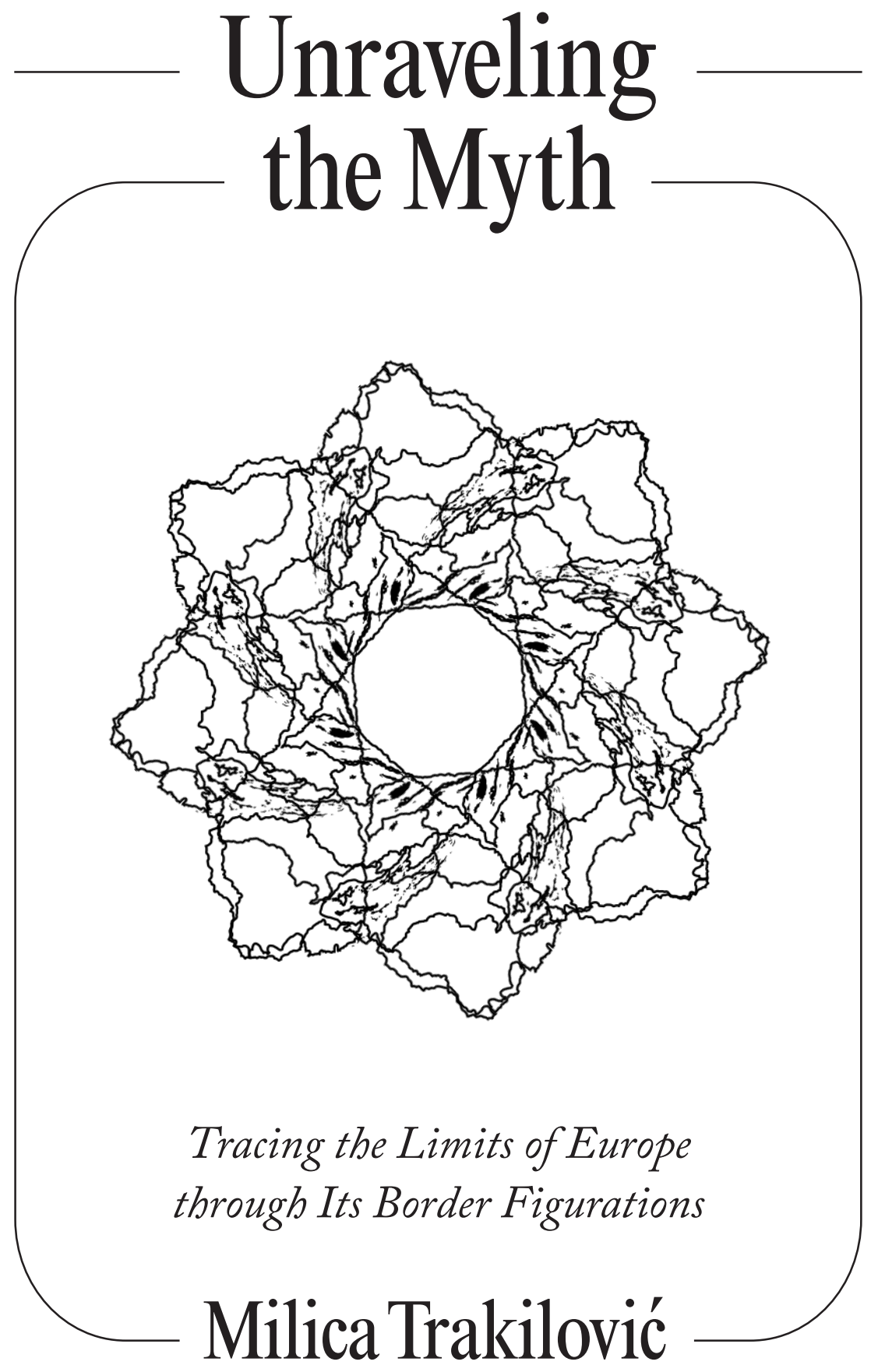


(C) 2020, MILICA TRAKILOVIĆ

ISBN: $978-94-92308-98-6$

All rights reserved. No parts of this book may be reproduced, in any form, without written permission from the author.

Graphic design: Yin Yin Wong

Printing and binding: Publication Studio Rotterdam

Cover image: Outlined map of former Yugoslavia in kaledoscopic arrangement. 
Acknowledgements ............................................ 7

English Summary ............................................ 9

Nederlandse Samenvatting...................................... 11

PART I —INTRODUCTION................................... 13

Mapping the Field .................................... 15

Research Questions and Chapter Outline....................... 18

Contextualization and Questions......................... 18

Chapter Outline ..................................... 24

Theoretical Framework...................................... 31

The Myth of Europe .................................... 31

Europe as a Discursive Formation .......................... 32

Historical Erasure and Otherness ........................... 37

The East/West Divide.................................. 42

Thinking Border Figurations Together..................... 45

Methodological Reflections .................................. 49

Analytical Scope and Approach........................... 49

Principles of Discourse Analysis .......................... 50

Foregoing Linearity .................................. 53

PART II —ARTICLES...................................59

Article 1 / Bodies Making Spaces:

Understanding The Airport As A Site Of Dissonance

Introduction ......................................6 61

Methodological framework and conceptual approach ...........6 63

Phenomenology of the airport ........................... 72

Conclusion ....................................... 80

Works Cited ......................................... 82

ARTICLE 2 / Between "Fleeing" and "Taking Flight":

Negotiating the Refugee Label

Introduction ....................................... 85

Analytical and Methodological Framework.................. 88

Negotiating Belonging through the Refugee Label............. 91 
Concluding Remarks ............................... 107

Works Cited .......................................... 109

ARTICLE 3 / On this path to Europe" - the Symbolic Role of the 'Balkan corridor' in the European Migration Debate

Introduction ....................................... 111

Europe and the other Europe............................ 114

Responses to the Balkan corridor ........................ 117

The Balkan corridor as a confrontation with abjection........ 121

Conclusion ......................................... 127

Works Cited ...................................... 130

ARTICLE 4 / Passing through: Negotiating Identity,

Sexuality and Movement in Ahmed Imamović's Go West

Abstract.......................................... 133

Introduction ...................................... 133

Synopsis......................................... 136

Key Intersecting Configurations........................ 137

Transitory Moments.................................... 139

Irreconcilable Differences between East And West........... 142

Conclusion ........................................... 147

Works Cited ........................................... 149

\section{ARTICLE 5 /"The Other Within": Challenging}

\section{Borders from the European Periphery}

Abstract......................................... 151

Introduction ...................................... 152

Balkanism and the Art of Disidentification................ 154

Balkanism as Mimetic Performance ....................... 159

Performing Gender, Unsettling Borders.................. 167

Conclusion ........................................ 173

Works Cited........................................ 174 
PART III —AFTERWORD .....................................177

On Narration, Belonging and Unhoming ................... 179

Works cited.............................................. 186

Curriculum Vitae ..............................................187 



\section{ACKNOWLEDGEMENTS}

Thanks to my supervisors, Rosemarie Buikema and Sandra Ponzanesi. Rosemarie, your guidance and trust urged me to map out the research into exciting and unexpected territory and to follow my own path. What a gift. Sandra, your encouragement made me rise to the challenge of new academic avenues and projects that have enriched my work, and myself. I am grateful to you both in particular for your involved and attentive engagement in the final stage of writing, which was the most difficult, and the most fun. You motivated me to nurture, sharpen and cultivate my voice and ideas, and for this I am immensely grateful.

In Florence, Italy, I am greatly indebted to the researchers involved in the ERC project Bodies Across Borders in Europe: Oral and Visual Memory in Europe and Beyond. In particular, I am thankful to the project coordinator, Luisa Passerini for the incredible opportunity to immerse myself into ethnographic research and to have my role of Research Assistant be such a diverse, rewarding and dynamic experience. Thanks to all the researchers involved in the project: Graziella Bonansea, Giada Giustetto, Leslie Hernández Nova, Iris van Huis, Liliana Ellena and Gabriele Proglio, for being a source of inspiration and motivation. A special thanks to those individuals that I met through my interviews, for being so generous with their time and their stories. The $B A B E$ project was an instrumental element in my $\mathrm{PhD}$ trajectory, as my dissertation features some of the research that has emerged from it, and I cannot imagine this process without this valuable experience.

In Utrecht, thanks to my fellow $\mathrm{PhDs}$ and my colleagues from the Graduate Gender Programme. Over the years, as I navigated the challenging task of balancing teaching with $\mathrm{PhD}$ research, I have felt a great deal of support, encouragement and genuine excitement from this one-of-a-kind community. I do not take any of it for granted. A special thanks to my colleague Koen Leurs for the many consultations over coffee, for sharing his knowledge and time and for listening when I embarked on a new research path, and beyond that. Also thanks to Trude Oorschot for her calm resolve, making organizational matters 
manageable and comprehensible, for reminding me of what needed to be done, and for answering all of my questions. Thanks to my peers from the PhD Reading/Writing Seminar: Laura Candidatu, Zerrin Cengiz, Desi Dwi Prianti, Deirdre Donoghue, Sara Verderi, Rosa Wevers and others, for your attentive reading, for commenting on my work at different stages, and for cheering me on.

I am so thankful for my wonderfully eclectic, caring and funny group of friends; my Rotterdam base and my Bosnian prava raja. I consider myself exceptionally fortunate to have such a dear and devoted community; all of the struggles and hardships over the past years were made bearable, if not easy, because of your company. A special thanks to my friend Aleks Gosto for the many comforting talks and consultations over Skype, for the ones still to come in the coming weeks, and the ones beyond that, as our research paths continue to converge and be a source of mutual inspiration. To my friend Yin Yin Wong, thank you for your characteristic enthusiasm, passion and eye for detail, all of which you have put into the design of this book.

Finally, I am deeply thankful to

Milijana, my mom — for setting an unparalleled example in loving dedication and perseverance.

Gaspard, my constant - for your inquisitive and nurturing spirit, for your devotion, the care, the laughter.

Miloš, my brother — for your ceaseless commitment; to joy, inquiry, life, and poetry. 


\section{ENGLISH SUMMARY}

Notions such as insularity, historical erasure and racial and cultural homogeneity all constitute the European myth and contribute to the idea of Europe as an exceptional place. This is further legitimized by discursive, institutional and symbolic processes of inclusion and exclusion as well as the instituting of borders in the name of Europe. Drawing on postcolonial and feminist theory, as well as border studies, cultural studies and postsocialist scholarship, I study Europe as a discursive formation that is operationalized through the instituting of material and symbolic borders. My highlighting of these bordering mechanisms is a simultaneous critique of their workings by showcasing their inherent fallibility, alongside which I offer different forms of critique, in the form of artistic interventions and individual narratives that open up the question of Europe to alternative significations.

This dissertation represents a critical interrogation of the idea of Europe from two vantage points that I conceptualize as border figurations in a European context: the figure of the refugee-migrant, and the geopolitical space of the Balkans, with a specific focus on the former Yugoslavia. These figurations represent peripheral actors and phenomena that are relegated to Europe's limits, but also potent discursive clusters that are operationalized together in light of the recent European migration 'crisis' and the European Union's eastward expansion towards the Balkans. The two border figurations are foregrounded here analytically in order to glean insight into Europe's historical self-definition vis-à-vis the (cultural) Other.

The intervention I make in this dissertation is three-fold. First, I combine an analysis of institutionalized and enacted bordering practices and discourses in Europe with a foregrounding of critical knowledges, practices and articulations that interrogate those very same processes. Secondly, I critique the 'exceptionality' and anxieties surrounding the current European migration crisis by placing this phenomenon in a larger historical and sociopolitical context, through a postcolonial engagement with the postsocialist area and idea of the Balkans. Third, in 
order to study the heterogeneity of European borders in their personal, institutional and symbolic dimensions, I use a variety of research material, including interviews, visual art, political narratives, film and public spaces. The data set is complemented by an interdisciplinary methodological approach that most prominently features discourse analysis, while drawing further on ethnography, oral history, semiotics, psychoanalysis and visual studies.

I use the concept of the border as a tool with which to expose and offer a critique of a dominant conceptualization of Europe, oftentimes predicated on colonialism, nationalism, whiteness, and a Westerncoded understanding of civilizational progress. Furthermore, I use the border as a way to trace the conditions of existence of those (individuals, populations, domains) who are subjected to the workings of the border apparatus. Through the notion of the border, I look at the processes of inclusion and exclusion as they occur in the European domain, spatially and discursively. These processes are mediated and mobilized by certain understandings of belonging, nationhood and 'proper' Europeanness in $2 \mathrm{I}^{\text {st }}$ century Europe. Studied together, the refugee-migrant and the Balkans as border figurations complicate any simple or 'easy' idea of Europe or Europeanness, providing useful ground for interrogating bordering practices and erasures, spatial and symbolic, that are enacted in the name of Europe. 


\section{NEDERLANDSE SAMENVATTING}

Begrippen als insulariteit, historische uitwissing en raciale en culturele homogeniteit vormen allemaal de Europese mythe en dragen bij aan het idee van Europa als een uitzonderlijke plek. Dit wordt verder gerechtvaardigd door discursieve, institutionele en symbolische processen van insluiting en uitsluiting, evenals door het instellen van grenzen in naam van Europa. Op basis van postkoloniale en feministische theorie, gender studies, cultural studies en postsocialistische wetenschap, bestudeer ik Europa als een discursieve formatie die wordt geoperationaliseerd door het instellen van materiële en symbolische grenzen. Mijn aandacht voor deze aangrenzende mechanismen is een gelijktijdige kritiek op hun werking door hun inherente feilbaarheid te tonen, waarbij ik verschillende vormen van kritiek bied, in de vorm van artistieke interventies en individuele verhalen die de kwestie van Europa voor alternatieve betekenissen openen.

Dit proefschrift vertegenwoordigt een kritische ondervraging van het idee van Europa vanuit twee invalshoeken die ik als grensfiguren in een Europese context conceptualiseer: de figuur van de vluchteling-migrant en de geopolitieke ruimte van de Balkan, met een specifieke focus op het voormalige Joegoslavië. Deze figuren vertegenwoordigen perifere actoren en fenomenen die zijn verbannen naar de grenzen van Europa, maar ook krachtige discursieve clusters die samen worden geoperationaliseerd in het licht van de recente Europese migratie 'crisis' en de oostelijke expansie van de Europese Unie naar de Balkan. De twee grensfiguren worden hier analytisch op de voorgrond geplaatst om inzicht te krijgen in de historische zelfdefinitie van Europa ten opzichte van de (culturele) andere.

De interventie die ik in dit proefschrift mak is drieledig. Eerst combineer ik een analyse van geïnstitutionaliseerde en vastgestelde grenspraktijken en discoursen in Europa met een voorgrond van kritische kennis, praktijken en articulaties die precies dezelfde processen ondervragen. Ten tweede bekritiseer ik de 'uitzonderlijkheid' en zorgen rond de huidige Europese migratiecrisis door dit fenomeen in een 
grotere historische en sociopolitieke context te plaatsen, door een postkoloniale betrokkenheid bij het postsocialistische gebied en het idee van de Balkan. Ten derde, om de heterogeniteit van Europese grenzen in hun persoonlijke, institutionele en symbolische dimensies te bestuderen, gebruik ik een verscheidenheid aan onderzoeksmateriaal, waaronder interviews, beeldende kunst, politieke verhalen, film en openbare ruimtes. De dataset wordt aangevuld met een interdisciplinaire methodologische benadering met een nadruk op discoursanalyse, terwijl verder wordt voortgebouwd op etnografie, orale geschiedenis, semiotica, psychonalyse en visuele studies.

Ik gebruik het concept van de grens als een hulpmiddel om een dominante beeldvorming over Europa, vaak gebaseerd op kolonialisme, nationalisme, witheid en een westers gecodeerd begrip van de vooruitgang van de beschaving, bloot te leggen en kritiek te bieden. Verder gebruik ik de grens als een manier om de bestaansvoorwaarden te traceren van diegenen (individuen, populaties, domeinen) die onderworpen zijn aan de werking van het grens als mechanisme. Door de notie van de grens kijk ik naar de processen van insluiting en uitsluiting zoals deze zich voordoen in het Europese domein, ruimtelijk en discursief. Deze processen worden gemedieerd en gemobiliseerd door bepaalde opvattingen over verbondenheid, natie en 'juiste' Europeesheid in het Europa van de 2 re eeuw. Samen bestudeerd, de vluchteling-migrant en de Balkan als grensfiguren bemoeilijken elk eenvoudig of 'gemakkelijk' idee van Europa of Europeesheid, en bieden nuttige grond voor het ondervragen van de aangrenzende praktijken en uitwissingen, ruimtelijk en symbolisch, die zijn vastgesteld in naam van Europa. 
Part I

Introduction 



\section{Part I}

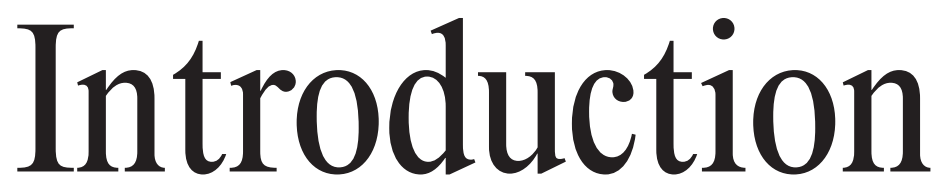

\section{Mapping the Field}

I remember being around eleven years old, attending primary school in the Netherlands. The subject was geography — we were studying the makeup of Europe, learning about the different countries and memorizing their position on the map, as well as their names and capitals. The teacher has printed out black-and-white handouts of the map of Europe that he is about to pass out to each of us, but before he does so, he says he needs to explain something. Turning the copy that he is holding in his hands towards us, I see that all the countries on the map are clearly delineated according to their national borders and their names are printed on the sheet - except for the space of the former Yugoslavia, which has been left completely blank. The teacher is addressing the class, but looking at me, as he explains how, due to the tumultuous situation in that part of Europe, he simply did not know which countries to put on the map in the former Yugoslav space, since the whole thing is "up in the air" at the moment. He shrugs, laughs a bit nervously, looks at me apologetically, and suggests that we therefore skip learning about this part of Europe altogether. I am disappointed - I had only started attending this primary school the year prior and was the only one in our class who was from 'somewhere else.' I had been looking forward to this class, hoping that by being able to situate this 'elsewhere' on the map I would be able to somewhat demystify what I 
felt was my still alien presence among my peers. But, I understand and nod, giving my permission to proceed as the teacher suggested. This was 1998; at this moment, the war in Kosovo is happening. Yugoslavia had started breaking up in 1991; by 1998, Slovenia, Croatia, Bosnia and Herzegovina, Serbia and Montenegro and Macedonia had all emerged and been recognized as independent successor states.

I remember another moment, from what must have been around the same time. I am watching something on the television in our living room - I cannot recall the exact context of what was being reported on, I only remember seeing moving figures, and the narrator's voice talking about 'refugees.'The entire memory is much more blurry than the previous one, but the only thing that stands out sharply is that, following this televised segment, I turn to my parents and ask whether we (meaning our family), too, are refugees - and they confirm that indeed we are. At this point, we had been living in the Netherlands for around three years, two of which had been spent in three different asylum seekers' centers. I had been attending Dutch primary school around a year, and had been receiving private lessons to bring me up to speed with Dutch language and with the Dutch school curriculum. Three years before that, in 1995, we had fled Bosnia and Herzegovina a couple of months before the Dayton Peace Agreement would be signed in November, bringing an end to the three-and-a-half-year war in Bosnia and Herzegovina. In a sense, ours was a 'typical' trajectory of displacement, marked by war, (forced) migration, followed by some kind of settlement. I remember the moment when I asked the question as the dawning of the realization that we had been refugees, whatever that meant, during this entire time. I felt ashamed for asking such as silly question and for not knowing - but until then, I truly had not fully grasped it. I suppose that I had had associated the word with a state of permanent displacement, drifting in and (mostly) out of existence, with being 'nowhere.' This did not correspond to my experience, because despite having been uprooted, I had always felt like I was 'somewhere,' the focus of my own cartography. I knew very well where I had come from, where I had been and where I was now. Identifying with that word, 'refugee,' was a 
disorienting experience, akin to being taken off the map, existing in the indeterminate 'nowhere.'

These two moments are clearly personal - two snapshots from my early childhood that are more than anecdotal, and which I thought back to often during the process of conducting my $\mathrm{PhD}$ research. While I could not make sense of them at the time, I can say now that what ties both memories together is that they are about borders, and about (not) belonging, as they speak to the state of being "in, but not of Europe." (Hall 2002, 57) I use them to map the research field of this dissertation - outlining both the topic and the question, that I will spend the rest of this Introduction laying out.

The first memory touches upon the makeup of Europe and the ambiguity, periphery and even absence of the former Yugoslavia/the Balkans in this geographic and imaginary space. Similarly, the second memory pertains to the positioning of the figure of the refugee-migrant in a (European) national context, as a non-citizen and a non-subject. It seems particularly fitting that these two snapshots headline this project; not only because I believe that "the personal is political," as the famous feminist slogan goes, but also because they tie together the different strands and questions in this research under the heading of negotiating and interrogating bordering processes and belonging in Europe. In that sense, the personal is also theoretical.

I am interested in how the idea of Europe takes shape in accordance with, or perhaps against, some of its peripheral(-ized) entities, in this case the region of the Balkans and the figure of the refugee-migrant. What role does the space of the Balkans occupy in the European imaginary? What role does the figure of the refugee-migrant ${ }^{\mathrm{x}}$ play in the configuration of Europe? In seeking to answer these questions, my

1 The conflation of the terms 'refugee' and 'migrant' into one word is not a callous gesture, but is rather meant to signify how these two categories have often become interchangeable in popular and political discourse in Europe today, especially in light of the European migration 'crisis.' In this dissertation, the term refugee-migrant is used to highlight a perceived cultural and ideological incompatibility in the European context. 
aim is not only to find answers about how Europe is constituted according to borders, 'real' and imaginary, that posit who belongs and who does not, what is inside and what is outside, what counts as history and what has been historically obscured. I am, in other words, not only interested in the 'myth' of Europe (although my fascination with the creation and dissemination of narratives of belonging is endless), for as Stuart Hall stated, "myth analysis is not enough. There is also the necessary work of deconstruction." (2002/2003, 65) In outlining a dominant configuration of Europe that takes shape around its (imaginary) peripheries, I aim to not just emphasize the ideological hold of this condition, but also, and significantly, "to reverse the resident hierarchy," (Spivak I976, 1xxvii), i.e. to question this established meaning and argue for other possible significations. Therefore, this dissertation, made up of five chapters, each with its specific point of reference to the question of Europe, represents both a critical account of (the idea of) Europe, as well as a contestation of that same phenomenon. It highlights both a dominant configuration of Europe as well as an intervention into that narrative. It asks how borders are administered in the name of national/European unity, while simultaneously acknowledging that borders are porous and permeable, and always in the process of being transgressed.

\section{RESEARCH QUESTIONS AND CHAPTER OUTLINE}

\section{Contextualization and Questions}

This dissertation represents a critical interrogation of the idea of Europe from two vantage points that I conceptualize as border figurations in a European context: the figure of the refugee-migrant, and the geopolitical space of the Balkans, with a specific focus on the former Yugoslavia. I understand the border as a figuration, in line with the work of noted feminist scholars such as Donna Haraway, who posited the figuration of the cyborg (1985); Rosi Braidotti, who theorized the figuration of the nomadic subject (1994; 20II) and Gloria Anzaldúa, whose la mestiza 
(1987) functions as a figuration of the borderlands. A figuration is a metaphorical entity with which to think through existing phenomena in a critical, non-prescriptive way; a figuration is something with which to open up a topic for (new) scrutiny, a guide with which to ask questions that may not have been asked yet, or a way to think differently about a phenomenon. There is also an element of undoing in the notion of the border figuration, since I understand it as a continually shifting entity, so that the very act of writing through the border desolidifies the thing that is under scrutiny - like the idea of Europe as an ahistorical and raceless phenomenon.

Thus, border figurations represent analytical entry points into interrogating the meaning of Europe. Being that meaning is not straightforward nor straightforwardly contained, studying how meaning comes to be established necessitates a multifaceted analytical approach. To elaborate, I am foregrounding here a passage from Joan Scott's seminal article Gender: A Useful Category of Historical Analysis (1986, 1067), in which she explains which levels of analysis need to be considered in order to pursue meaning (recognizing that this pursuit is indefinite, since meaning is never fixed):

To pursue meaning, we need to deal with the individual subject as well as social organization and to articulate the nature of their interrelationships, for both are crucial to understanding how gender works, how change occurs. Finally, we need to replace the notion that social power is unified, coherent, and centralized with something like Foucault's concept of power as dispersed constellations of unequal relationships, discursively constituted in social "fields of force."Within these processes and structures, there is room for a concept of human agency as the attempt (at least partially rational) to construct an identity, a life, a set of relationships, a society with certain limits and with language-conceptual language that at once sets boundaries and contains the possibility for negation, resistance, reinterpretation, the play of metaphoric invention and imagination. 
Scott emphasizes the need to look at both micro and macro levels of analysis when building a critical argument about a phenomenon that is so integral to social life and experiences, like gender. Scott's definition of gender is built on two interconnected propositions, namely: "gender is a constitutive element of social relationships based on perceived differences between the sexes" and "gender is a primary way of signifying relationships of power." (Ibid.) Regarding the first proposition, Scott distinguishes between four ways in which gender manifests and is operationalized: in cultural symbols, normative concepts, institutions and in subjective identity. ${ }^{2}$ In this view, it is not enough to say something about how gender works by looking solely at cultural symbols, experiential accounts, nor at how gender is instrumentalized on a structural level by institutions, although all are significant levels of analysis. In order to have a more robust account of how power functions in the Foucauldian tradition, ${ }^{3}$ one that can attest to its oppressive character and the agential

2 Some elaboration on the relationship between cultural symbols and normative concepts is necessary here. According to Scott, cultural symbols of gender exist in a large repertoire of meaning, to be found in discourses and representations which are multiple and often contradictory ('woman,' for instance, can signify both innocence and purity, as well as corruption). Normative concepts are those cultural symbols that become ideologically fixed and promoted through official doctrines (Scott gives the Victorian ideology of domesticity as example). (I986, ro68) Both manifestations of gender are linked, in that those cultural symbols that become ideologically inscribed and enforced turn into normative concepts. In my own analysis, when I say I am studying Europe at a symbolic level, I am referring to both dimensions: multiple and contradictory cultural repertoires, as well as more ideologically fixed (normative) meanings of Europe.

3 The Foucauldian conceptualization of power is one that dispels with the notion that power equals control held by an elite individual or group, who then exerts this control over society. This top-down configuration of power is replaced in a Foucauldian theoretical framework with a much more complex circular model, in which power is never in the hands of a single entity, as it is redistributed and transformed over time and in different contexts. Power is thus something than can be mediated, and no one individual or group is ever fully 'oppressor' or 'oppressed', although this does by no means mean that power is distributed equally, as it can benefit some actors and collectives more than others. This conceptualization of power should be thought of as a system that is both repressive and productive and present in every facet of experience: individual 
possibilities that emerge through that same power nexus, it is necessary to think of all dimensions as always already entangled. Although Scott's argument is centered on gender as the central category of analysis, she makes clear that the analytical framework she proposed could be used for other types of analyses as well, such as "class, race, ethnicity, or, for that matter, any social process." ( 1986, 1069) In my dissertation, I apply this analytical framework to processes of belonging in Europe that signify relationships of power (Scott's second proposition) and thus constitute and challenge the European myth.

Applying these principles to the study of Europe means that the narrative of it that emerges here is not singular; rather, it represents the entanglement of co-constituting levels of meaning, namely: the personal, the institutional and the symbolic. In Scott's words, "instead of a search for single origins, we have to conceive of processes so interconnected that they cannot be disentangled." (1986, I067) To illustrate the merit of this approach, I come back to the example of the geography lesson which opened this Introduction. The teacher's choice to not include the space of the former Yugoslavia in the map of Europe was justified by the fact that the geopolitical transitions and new borders in that region had not (yet) been sufficiently institutionalized (at the very least, not in the primary school curriculum in the Dutch south). This was subsequently the motivation for the symbolic removal of the former Yugoslavia from the map of Europe, which I experienced as personal erasure, a dismissal of my own subjectivity and trajectory. Foregrounding only one of these dimensions would not do justice to the breadth of meaning nor to the complexity of experience. That is why, while certain chapters here may focus on a particular levels of analysis over others, the dissertation as a whole considers the construction of Europe through the entanglement of the personal, the institutional and the symbolic domain.

and collective, social and political. Power in this sense "traverses and produces things, it induces pleasure, form of knowledge, produces discourse. It needs to be thought of as a productive network which runs through the whole social body." (Foucault I980, I9; Hall 2013, 34) 
My study of Europe through border figurations is further complemented by border studies scholarship, notably Étienne Balibar's works on the equivocal character of borders. $(2002,78)$ Theorizing the impossibility of defining the border, Balibar nevertheless posits three main characteristics of the functioning of borders: they are overdetermined (they never merely indicate a separation between states, but are inflected by historical and political developments); they are polysemic (meaning that they do not exist for everyone in the same way and are thus experienced differently depending on one's positioning) and they are heterogenous and ubiquitous (i.e. not only situated at official border controls, but frequently dispersed throughout society). $(78-79)$ For Balibar, borders are thus not static entities that are controlled and enacted by states alone; rather, as discourses and processes, they are ephemeral phenomena and exist at the same time "everywhere and nowhere." (78) Following Balibar, I am motivated by an understanding of borders in general, and Europe and Europeanness in particular, as a complex set of discursive practices that have material effects.

Such a complex configuration of borders invites an elaborate analytical framework, which in my case will be guided by the multi-layered analysis that Scott proposes and that I have outlined above. Moreover, it requires that the question at hand (the question of Europe in this case) be engaged with through the study of different materials, modalities and genres. The intervention I make in this dissertation is three-fold. First, I combine an analysis of institutionalized and enacted bordering practices and discourses in Europe with a foregrounding of critical knowledges, practices and articulations that interrogate those very same processes (or, in other words: myth analysis accompanied by deconstruction). Secondly, I critique the 'exceptionality' and anxieties surrounding the current European migration crisis by placing this phenomenon it in a larger historical and sociopolitical context, through an engagement with scholarship on Europe's postsocialist region from a postcolonial lens. Third, I use a variety of material in order to study the heterogeneity of European borders in their personal, institutional and symbolic dimensions, including interviews, visual art, political narratives, film and public spaces. 
From this emerges the following research question:

How can the region of the Balkans and the figure of the refugee-migrant be jointly understood as border figurations with which the 'myth' of Europe can be traced and interrogated?

The main question is comprised of the following sub-question:

How can Europe be understood as a discursive border regime that produces material effects?

How can current sociopolitical European phenomena, such as the European 'migration crisis,' be assessed in a deeper historical Ẽ postcolonial perspective?

What is to be gained from engaging with the postsocialist region and its political transitions through a postcolonial framework?

The main question and three subquestions are addressed, in different modalities, throughout the five chapters that make up this dissertation. What follows next is an outline and brief discussion of each chapter, in the order in which they appear in this dissertation. After the outline, I will extract the main thematic strands from the chapters in order to situate the research into relevant scholarly debates and discuss the further theoretical and methodological makeup of the dissertation. I work with something of an inverted model in this Introduction: starting from the research conducted and then expanding on its theoretical and methodological embedding, rather than the other way around. This is to highlight the ways in which the chapters, notwithstanding their thematic differences, speak to each other and present a narrative into and through Europe.

The narrative to a large extent echoes the direction of my personal trajectory: at a young age, I emigrated from the former Yugoslavia (present-day Bosnia and Herzegovina) to the Netherlands, as a result of 
the Bosnian war in the early I990s. As my childhood and adolescence were characterized by frequent and unstraightforward mobility, both physical (from Bosnia to the Netherlands and back again, and back again) and structural (from citizen to stateless to refugee to citizen), my understanding of nationhood and belonging in general, and in a European context in particular, is anything but straightforward. Having, at different points in my life, been both 'insider' and 'outsider' in various national contexts in Europe, nowadays I experience a strange kind of comfort in my 'fractured' sense of self, which is why I am all the more fascinated by narratives that promote any kind of taken-for-granted notion of (national) unity. As Balibar has noted, “...the state as nation state is a formidable reducer of complexity, though its very existence is a permanent cause of complexity, which then falls to it to reduce...” $(2002,77)$ This dissertation aims to highlight some of the complexities that are reduced in the name of unity in a national, European context, and in doing so, open up possibilities for different conceptualizations of belonging and being in Europe. A different account of Europe emerges when considered from the European (cultural, political, symbolic) peripheries - East and Southern Europe, and the Balkans in particular, for instance. Similarly, the concept of national unity becomes complicated when considered from the position of the nation's peripheral subjects or its non-citizens - migrants, refugees and foreigners.

This dissertation is then a study of Europe re-oriented through some of its border figurations, represented by the figure of the refugee-migrant and the region of the Balkans. I do recognize that these are but two of the many potential peripheral entities/constituent outsides that make up Europe; however, I believe that the simultaneous focus on the role of the Balkans and the figure of the refugee-migrant in the current European imaginary contributes to the analytical rigor of this research by offering a multifaceted and situated account of Europe. 


\section{Chapter Outline}

The first chapter, titled Bodies Making Spaces: Understanding the Airport as a Site of Dissonance, was published in the edited volume Dissonant Heritages and Memories in Contemporary Europe (Lähdesmäki, Passerini, Kaasik-Krogerus \& van Huis, 2org). This chapter is an entry point into the question of Europe, and as such it represents arrival in literal and symbolic terms. The analysis consists of a phenomenological reading of Schiphol, the Dutch national airport situated near Amsterdam, based on an interview I conducted in 2017 in the context of the Bodies Across Borders in Europe: Oral and Visual Memory in Europe and Beyond ${ }^{4}$ (hereafter $B A B E$ ) project with a young Syrian man on the topic of his arrival at Schiphol Airport and his time spent at the Schiphol detention center when he applied for asylum. His experience of controlled movement and detention is contrasted with my own quotidian experience of relatively open and unobstructed movement through the airport. I consider Schiphol airport as a complex, together with the less publicly known Schiphol detention center in the vicinity of the airport. More than a zone of transit, this complex is the site of intricate bordering processes, literal and symbolic. I argue that Schiphol is a site of Dutch cultural heritage and therefore a part of the Dutch cultural archive (Wekker 20I6) in which cultural and national politics of belonging are being promoted, enforced and negotiated. The specific

4 From May 20I5 until May 2018, I was Research Assistant in the ERC project Bodies Across Borders in Europe: Oral and Visual Memory in Europe and Beyond (BABE), situated at the Department History and Civilization at the European University Institute in Florence, Italy, with cultural historian Luisa Passerini as the Principal Investigator. During this time, I conducted ethnographic research in the Netherlands (in the form of interviews in the oral history tradition) with individuals with a migration background on the topic of their trajectories to (and through) Europe. This research has resulted in two chapters (both parts of edited volumes) that are included in this dissertation as Chapter I and Chapter 2.

The BABE project was funded by the European Research Council under the European Union's Seventh Framework Programme (FP/2007-2013) / ERC Grant Agreement n. 295854. 
focus on the politics of detention is important for any consideration of contemporary borders, especially since "sites of detention have become objects of political anxiety." (Mezzadra and Neilson 2013, I47) The managing and detaining of bodies at airports in the name of order should be understood as mirroring other places that contain a significant amount of difference and cultural heterogeneity in Europe, like urban centers, "where questions of proximity to others are heightened." (Modest \& de Koning 20I6, 99) Proximity to difference thus feeds into anxieties about the cultural/racial Other intruding upon the national space, which prompts the institutionalization of borders. The analysis of Schiphol shows how this is achieved through the spatial ordering of difference. This chapter demonstrates how the border is enacted as a top-down process that feeds into already existing ideas about contained cultural and national belonging in Europe.

Whereas the first chapter focuses primarily on how top-down bordering processes become spatialized and institutionalized, the second chapter considers how the border in its symbolic or "narrated" (Chouliaraki 20I7) form becomes negotiated by the subjects who are marked by it. Titled Between "Fleeing" and "Taking Flight": Negotiating the Refugee Label, this chapter is part of the edited volume The Mobility of Memory: Migrations and Diasporas across European Borders (Passerini, Trakilovic, Proglio, forthcoming October 2020). Like Chapter I, it is based on my fieldwork in the $B A B E$ project and features sections from several interviews ${ }^{5}$ conducted between 2015 and 2017 with refugees and $\mathrm{mi}^{-}$

5 Some notes and reflections on the process of interviewing are pertinent here. The interviews had a semi-structured format, conducted according to a thematic outline, or a 'topic list,' but with enough leeway in the process to include elements that have not been accounted for in the planning of the interview. With semi-structured interviewing, there is "room left for spontaneity on the part of the researcher and interviewee." (Hesse-Biber 20I4, I87) These interviews had a certain reciprocity to them, particularly because I could relate my own experience of forced migration in the I990s to my narrator's experiences of mobility and displacement, which overall likened the interview to an exchange, rather than a give-and-take, of experiences. Although the chapters of this dissertation that feature these interviews foreground my narrator's stories, it should be understood that I am also always 'in there' as well, as a listener, 
grants living in the Netherlands. The chapter considers the experience of being 'labelled' as either migrant or refugee in the current European political context, marked by discourses of fear and suspicion regarding the perceived influx of cultural Others. It highlights the act of rejection of the migrant/refugee label that I recognized in many of my narrator's self-identifications, being familiar with the act of disidentification with the word 'refugee,' as I noted earlier in this Introduction. These acts are subsequently contextualized in two ways: first, as a critique towards the current political climate in Europe that frames migrants, refugees and asylum seekers as invaders of a distinctly European space. In this way, the individual disidentification with the undesirable label becomes positioned as a critique of the larger framework which produces these constraining categories. Secondly, through the conceptual framework of the border, the act of disidentification is conceptually reconfigured more fittingly as an act of negotiation. Disidentification may appear

interpreter and as somebody whose experiences of migration and mobility both echo and differ from their own. Further, the interviews were based on the oral history tradition, which is predicated on listening to, and making space for, (life) narratives of subjects, often those who have been absent from, or not (sufficiently) accounted by history. Oral history as a genre exists, as Alessandro Portelli poignantly writes, in "the rich heteroglossia resulting from a dialogic shaping of discourse." $(2002,3)$ This means that, while there is in the oral history tradition typically a narrator that provides a narrative of the memory of a life or an experience, and a listener who takes notice, writes down and/or records this narration, the oral history account is better understood as something that both do "together at the moment of their encounter in the interview." (ibid.) This principle extends beyond the interview as well, when it comes to the process of transcribing, interpreting, theorizing, writing down and publishing the story in its final form. The process is a dialogic one, and the eventual narrative form is significantly shaped by the researcher. By highlighting this relationship, I do not mean to elevate my own voice at the expense of the narrators that are featured in this dissertation; their stories are always their own, and I have been humbled by having heard them. However, in an attempt to write "with" rather than solely "about" (Sultana 2007) the individuals I interviewed, I do think it is important to acknowledge how "methodology provides information about the various ways in which one located oneself." (Wekker 2006, 4) Thus, the interviews that have become integrated in the chapters of my dissertation emerged out of a dialogic process of exchange. 
like a too straightforward rejection of the undesirable label ('a line in the sand'), whereas negotiation more appropriately describes a situation in which the label is constantly being re-mediated, its meaning never fully fixed. As such, this chapter highlights "the notion of border struggles" as "the set of everyday practices by which migrants continually come to terms with the pervasive effects of the border, subtracting themselves from them or negotiating them." (Mezzadra \& Neilson 20I3, I3) The emphasis on negotiation allows for a less rigid conceptualization of the refugee-migrant category, one that is both a constraint and a possibility.

The third chapter brings together the two conceptual entry points that are used to interrogate the idea of Europe; the figure of the refugee-migrant and the region of the Balkans. Fittingly, this middle chapter acts as a thematic bridge in the context of the dissertation, whilst its topic of analysis is also a bridge of sorts. Titled "On this Path to Europe" - The Symbolic role of the 'Balkan Corridor' in the European Migration Debate, Chapter 3, a contribution to the edited volume Cultures, Citizenship and Human Rights (Buikema, Buyse \& Robben, 2019), is a study of the previously laid out political anxieties surrounding the perceived threat of cultural Others in the specific context of the phenomenon of the 'Balkan corridor' or 'Balkan passage;' a relatively short-lived migration route that was in effect in late 2015 and early 2016 before it was permanently shut down by the so-called EU-Turkey deal. In order to understand the anxieties around the Balkan passage and its subsequent closure, I argue in this chapter that the figure of the migrant and the region of the Balkans need to be assessed together in their symbolic dimensions in the European imaginary. First, both topics are contextualized separately. I draw on Fatima El-Tayeb's work in European Others and David Theo Goldberg's theory of racial Europeanization to show how the contemporary cultural Other in Europe has been configured through the notion of the (Muslim) migrant. For the contextualization of the Balkans, I use, among other works, Larry Wolff's Inventing Eastern Europe (1994) and Maria Todorova's Imagining the Balkans (1997; 2009) in order to explain how the historical positioning of the Balkans in the European imaginary has worked according to a 
less traditionally straightforward Self-Other binary and more according to the notion of "the Other within." (Todorova 1997; 2009) Using a psychoanalytic approach centered on the notion of the abject (Kristeva I982), I then argue that the figure of the migrant and the ambiguous position of the Balkans 'met' in the period when the Balkan passage was in effect, and that this crossing of borders also represented a symbolic disturbance of Europe's identarian boundaries. This chapter explores the border in its structural and symbolic dimension in order to map political sentiments surrounding the rise and shutdown of the Balkan corridor that often (inadvertently) reaffirmed ideas of Europe as an exceptional place through a pathologization of the Balkans and the migrating subjects who followed this route on the way 'to' Europe.

The fourth chapter continues asking how the idea of Europe is shaped by an imaginary divide between the East and the West, according to which the West actually stands for Europe 'proper' and comes to represent a civilizational model against which the more compromised parts of Europe can be measured. From here on, I turn my attention to representational and artistic practices from the former Yugoslavia that engage with the question of belonging in/and Europe; cinema (this chapter) and visual art (the following chapter). Titled Passing through: Negotiating Identity, Sexuality and Movement in Ahmed Imamovic's Go West, this chapter was published as an article in the special issue on Cinemas in Europe (Ponzanesi \& Berger 20r6) in the Transnational Cinemas academic journal. While it thematically corresponds to the previous chapters, in that it continues exploring how notions of belonging are negotiated in a European context, this chapter's is specifically focused on the ways in which these political questions are addressed through the field of cultural production, which in this case is cinema. The chapter features an analysis of the 2005 Bosnian film Go West, which made waves when it first came out because it focused on the fictional story of two men in a romantic relationship, a Bosnian Muslim and a Bosnian Serb, during the Bosnian war in the I99os. The entanglement of sexuality and ethnicity provides another significant entry point into the question of belonging in Europe; as Bracke et al. argue, 
"inhabiting non-normative genders and sexualities is so intimately linked with crossing borders, with moving, with not-belonging." (20 I4, 206) Thus, there is in the film's synopsis a promise for a representation of nuanced and complex border-crossing practices to emerge in this configuration. However, while the focus on a homosexual relationship was deemed controversial and even transgressive at the time it came out, in my analysis I argue how a constrained portrayal of sexual identity in the film translates to a rigid notion of national and ethnic belonging as well. By portraying non-heterosexuality as an impossible identity in a pathologized Balkan context, the film suggests that progress and 'proper' civilization is found elsewhere as well, namely in the West. The divide between the West and East is constructed through a "progress narrative" (Navickaite 2014) which posits Western Europe as the European civilizational model, and Eastern Europe as forever catching up. Thus, a symbolic and discursive border is enacted through the film's narrative and specifically through the focus on non-normative sexuality and through a reiteration of existing discursive tropes that posit the Balkans as a corrupted entity in the European context. This chapter employs an intertextual approach, which makes it possible to explain how texts are always already "pre-coded" by other, previous contexts and discourses (Louw 200I, 209). This analysis shows how the discourse of the Balkans as backwards is not only a form of cultural stereotyping in the West, but is reiterated in discourses and cultural productions from the Balkans as well, thereby demonstrating the pervasiveness of this ideology — as well as the need to interrogate it.

The fifth and final chapter continues to ask how Europe constituted through border processes with a focus on cultural production from the Balkans. Titled "The Other Within": Challenging Borders from the European Periphery, this chapter was published in the edited volume Postcolonial Transitions in Europe: Contexts, Practices and Politics (Ponzanesi \& Colpani, 20I6). It foregrounds select visual art works by artists from the former Yugoslavia as border crossing practices, by which I mean a critical engagement with questions of belonging and nationhood in a European context. This final chapter again interrogates 
how a dominant idea of Europe emerges through a pathologization of the Balkans, through a discourse of Balkanism. However, the art works presented in this final chapter represent a "radicalization of binaries" (Grižnić 2007, 204) that engage with existing borders in a way that represents a proper interrogation and not simply a reiteration of existing borders. The three works were chosen because they all engage with the question of Europe through the space of the Balkans or the former Yugoslavia, and they all do so by adopting a strategy of "overidentification" or "the copy," that is a form of critique outside of the traditional sense: it represents critique through the embodiment of the very form/image that the art means to critique (Grižnić 2007, 20I), echoing Irigaray's theory of mimesis (1985) as "an improper transfer of sense." (Butler I993, I I) In the case of the three works analyzed in this chapter, the overidentification happens through the embodiment of a pathologized and culturally inferior version of the Balkans and through the sexualized image of the female Eastern European subject/migrant. By performing border crossing practices, the art pieces function as border figurations. Through the reiteration or embodiment of a negatively charged image, the art works do not simply reiterate the existing discourse (which is the case, as I argued, in the film Go West) but rather illuminate the workings of those bordering processes that bring into being the figure of the refugee-migrant or the inferiority of the Balkans in a European context. In so doing, this final chapter opens up the question of Europe for other possible significations, without claiming a final say in what those should look like.

\section{THEORETICAL FRAMEWORK}

\section{The Myth of Europe}

In this section, I will outline the main debates and theories that underlie my discussion of Europe. Before embarking on this discussion, I want to say that I am not looking to produce a definitive reading (as if such 
a thing were possible) of Europe; neither do I work with a clear-cut definition of Europe, nor of the border, or any other category of analysis for that matter. I study the question of Europe in this research in accordance with how Fatima E1-Tayeb frames her approach in Europe and its Others when she says: "What follows is thus less an exhaustive study of the European condition than a step in claiming that such a condition exists." (20II, xxII) Moreover, following Stuart Hall, I am aware the critique of Europe as a myth might result in an unintended establishing of yet another myth of Europe (2002/2003, 60-6I); one that has not been canonized but, in being formulated, even as critique, is nevertheless claiming entry into this framework. Doing critical work means that, in a sense, one is always reproducing the object of critique, always reinstating its importance. However, working in a deconstructive mode also means that one is also always in the process of undoing and reconfiguring meaning. Therefore, my aim in this dissertation is not to produce a fixed account of Europe, but one vital, situated, historically informed analysis of present-day Europe. I want to illustrate how Europe is discursively produced, and how it may emerge differently, when considered from some of the borders of Europe, i.e. positions and subjects that are rather peripheral in the way Europe has traditionally been envisioned. However, this should not be confused with privileging an unproblematized 'view from below,' (Haraway 1988, 583) which could result in producing an essentialist view, enacting another border. Rather, I lean on the principle of multiperspectivalism (Rumford 2012), which posits that borders can, and should, be studied from centers and peripheries both, combining top-down and bottom-up approaches, i.e. multiple levels of analysis.

\section{Europe as a Discursive Formation}

Writing about the 'myth' of Europe, Stuart Hall starts by asking some crucial questions: "Where does Europe begin and end? Has it always existed and if not, when did it start? What is the 'new' 
Europe's relation to its past? Which parts of Europe belong to 'the idea of Europe' and which do not?" $(2002 / 2003,57)$ I recall again the experience of the awkward geography lesson in primary school, the blotting out of an entire geopolitical area for the sake of convenience and continuity - a reminder that the question of Europe is always contested terrain. Hall's questions show that there is no clear definition of Europe, and yet, there is the idea of Europe that posits Europe as a centrality, embodying supposedly universal ideas such as "liberty, fraternity, equality" $(2002 / 2003,59)$ to the fullest. However, contrary to the way in which Europe has popularly presented itself, as insular and independent, its existence has actually always been predicated on changing conception of difference against which it could imagine itself. $(2002 / 2003,60)$ Europe is configured according to a constantly evolving repertoire of (constituent) others that shape (the idea of) Europe as well as its cultural imaginary. (Said I977; E1-Tayeb 20I ; Wekker 2016) In this sense, Europe can be understood as an imagined community, according to the influential argument by Benedict Anderson (1983; 2006). Anderson argued that national affiliations are felt strongly because of the way in which the nation is invented in and through discourse - national belonging exists because of the way in which the nation is imagined as a unity. Importantly, Anderson noted how "no nation imagines itself conterminous with humankind." (2006, 7) This means that the idea of national unity is successful because nations exist according to boundaries, both literal and figurative, delineating where the nation begins and ends, as well as who belongs and who does not. National affiliations thus also function according to principles of difference and otherness.

In the context of this dissertation, I understand the ways in which Europe has been historically imagined and presented according to the notion of a discursive formation. In a Foucauldian framework, knowledge and social practices are produced through discourse, which is more than language alone. Discourse is a practice through which meaning becomes produced, disseminated and institutionalized. Understanding Europe as a discursive formation is useful for three reasons. First, as 
Hall notes, "The question of whether a discourse is true or false is less important than whether it is effective in practice." (Hall I992, 205) Thus, studying the workings of discourse places an emphasis on understanding the complex ways in which power is distributed and organized, rather than asking the less productive question of whether a discourse is true or false. Discourse is both, and neither; it is true since it has real life consequences for subjects, social relations and the production of meaning, and it is false since a discourse is never going to be able to account for the full complexity of experience, and in that sense it will always be reductive. Discourse, in other words, simply is, and the more pressing question to ask is how it materializes and comes into effect. Secondly, since discourse produces meaning through language and social practices, "it has consequences for both those who employ it and those who are "subjected" to it." (Hall I992, 225) Studying Europe as a discursive formation makes it possible to understand how discourse is a dispersed phenomenon, never fully centralized (although some positionings and institutions enjoy claim to power than others) nor only operational in one context. This conceptualization of discourse complements Balibar's understanding of the border's equivocal character ("borders are everywhere") and necessitates an analytical framework that can account for the workings of discourse at different yet interconnected levels: personal, institutional and symbolic. Third, not only does this Foucauldian understanding of discourse presuppose a non-centralized, circulatory understanding of power, but it also does not conceive of power in purely negative terms. As Rosi Braidotti notes, "power is not only negative or confining (potestas), but also affirmative (potentia) or productive of alternative subject positions and social relations.” (2012, 22) Power in discourse does not only subjugate or repress, but also makes conditions of existence and expression possible, and in that space alternative configurations may arise - even ones that can question and upend the very foundations upon which the discourse has been built in the first place. This is significant, because this research considers how Europe is mediated as a top-down institutional practice, but through that it also highlights ways in which these discourses are negotiated (see, for instance, 
the 'refugee label' discussed in Chapter 2) and deconstructed (for instance, visual art from the former Yugoslavia, discussed in Chapter 5) from a more bottom-up perspective. Thus, understanding Europe as a discursive formation makes it possible to consider how it workings produce and institutionalize borders, but also how these borders are resisted and negotiated, and hence always in the process of being crossed.

I do not propose a conclusive account of Europe as a discursive or institutional power. As Rutvica Andrijašević writes, it must be kept in mind that

however polemically potent the image of 'Fortress Europe' [...] might be, it rather misses the point that the contemporary ordering of borders is much closer to a space of nodes and networks, of gateways, filters, and passage points, than it is to the old idea of borders as defensive lines. (2010, 985)

Thus, Europe does not emerge as all-powerful agent, but rather as an entity that does wield power in ways that are impactful, but that also can be contested. An emphasis should be placed, however, on the fact that discourses are not merely ephemeral phenomena; discourses produce tangible effects that are actualized through border institutions in Europe. Gurminder K. Bhambra argues that "the European project" takes shape through institutional frameworks like the European Union (EU) and the European Economic Community (EEC) that promote the idea of cosmopolitan Europe through a superficial view on difference and diversity, not accounting for history nor racial or cultural diversity within nation states. $\left(205_{5}, \mathrm{I}_{2}\right)$ The idea that the EU is a new political institution and has a "clean slate" (Bjelić 2018,752) from histories of racism and exploitation extends also to those members, notably Eastern European and Balkan countries, who have only recently and partially started gaining access to this institution. At the same time, those new members represent the boundary of the presumably cosmopolitan EU where stringent controls are most forcibly enacted and imposed on immigrants "as spatial-racial enemies" (ibid.) Spaces 
like the Balkans thus perform the role of safeguarding the open, internal space and character of the EU. Both the EU and the EEC are economic/political institutions, but they are also instrumental in shaping and promoting the story of Europe as an exceptional place, i.e. discursively instituting this European myth.

Another such institution is the Schengen zone, which overlaps significantly with the EU; a visa-free framework encompassing 26 European countries. Within the Schengen Area, passport controls have been abolished, promoting internal mobility, while (stricter) passport controls have been moved to the Schengen frontiers, like the Balkans. Institutions like Schengen may promote a post-national idea of intra-European unity and cosmopolitanism, but they operate according to nationalist frameworks still; under the guise of cosmopolitanism lies nationalist sentiment. (Derrida I992, 48) William Walters has dubbed this phenomenon "Schengenland" (2002), alluding to more than just its bureaucratic function. In asking "Does Schengen have its 'others'?" (570) Walters makes the link to how (European) nations function according to an imaginary, a repertoire of racial and cultural difference (imagined communities). Arguing that Schengen does not have 'others' in the traditional sense of the word (other nation states as geopolitical entities and potential military threats), Walter claims that Schengen does, nevertheless, function in relation to many figures of otherness, such as terrorists, refugees, traffickers, smugglers and other "folk devils:" often racialized subjects whose illegality (existence and/or practice) legitimates the further fortification of borders and strengthening of security checks at or right outside of the border. $(2002,570)$ To illustrate, consider how the 2015- I6 migration track (the 'Balkan Corridor' or 'Balkan Passage') through the Western Balkans en route to the Schengen area changed over time to allow passage only to Syrians, Iraqis and Afghans individuals, restricting it to all African and other nationalities and leaving them in imperceptible precarity, differentiating between 'acceptable' and 'unacceptable' populations and nationalities. There is a feedback loop between the European institutional/bureaucratic apparatus and the dominant conceptualization(s) of Europe that are consciously or 
unconsciously enacted through a proliferation of borders. Europe as imaginary and Europe as practice are therefore inextricably linked.

Discourse can also be understood as a bordering device in line with the distinction Lilie Chouliaraki's makes between "territorial barriers, the on-the-ground technological infrastructures that classify arriving populations, or what we may call the "enacted" border; and as representational barriers, the media portrayals that construe [...] populations as "desirable" vs "undesirable," or the "narrated" border." $(2017,536)$ The narrated border works as a discursive and representational device that symbolically keeps in place migrant groups and other undesirable populations to prevent them from spilling over into national/European frameworks, and in doing so works to further legitimize bordering infrastructures on the ground (see Chapter 2 on the migrant/refugee 'label' for an illustration of the narrated border).

Furthermore, to understand Europe as a discursive formation also means being able to assess its symbolic or imaginary quality. Some places and actors are more centrally embedded in Europe, more firmly 'inside,' while others' position in Europe is more peripheral and ambiguous. Balibar (2009, 199) speaks of the political ideology that puts forward the idea that Europe is made up of (at least) three concentric circles; the smallest one representing the core of Europe by belonging to the EU and sharing a single currency, while the outer circle is comprised of more peripheral nations in Europe, that are thus also less 'European' the more they are removed from the core. The countries that are not part of the European nucleus are not only spatially removed, but also historically and politically distanced from the center. Europe is therefore also a quality that, depending on their spatial, institutional and symbolic positioning, some places and actors can embody and possess more, and some less. These reflections show that much more than just a geopolitical entity, Europe should be understood as a discursive formation - an enacted idea and a set of narratives that have effects on people, policies and practices today. Therefore, the question of Europe is always already a political question. In what follows, I highlight two principles that have shaped the 'myth' of Europe and that are relevant 
for my research: historical erasure and otherness, and the East/West divide. I draw on scholarship on postcolonialism and postsocialism to situate the research in a larger academic debate on Europe.

\section{Historical Erasure and Otherness}

Europe has historically been imagined as an insular entity, a supposedly culturally and racially homogenous phenomenon. This belief is reinstated today through the anxiety-ridden discourses surrounding the European 'migration crisis.' In this context, Europe is frequently imagined as being 'overwhelmed' and overtaken by the influx of racial and cultural others, entering Europe from its peripheries (Greece, Italy, Turkey, the Balkans) and advancing to the mainland. ${ }^{6}$ The incline in populist discourses and conservative politics Europe-wide can be seen as a reaction to the perceived threat that migration to Europe represents. However, this presentist attitude fails to consider Europe in a more historical dimension, and in that way fails to account for the imperial and colonialist legacies that inform migration politics and policies in Europe today. As Paul Gilroy writes,

The political movements that have vowed to stop Europe's supposed Islamification and made a target out of immigrants, refugees, and sans-papiers are overwhelmingly populist in

6 Consider for instance how the mediatization of the current European 'migration crisis' is, in both popular and political jargon, often described through the use of so-called aquatic metaphors; expressions connected to bodies of water. There is talk about migrants "flooding" Europe and refugees arriving in "waves." The emphasis on aquatic-border crossings in popular discourse makes Europe appear as an island at times. Holmes and Castañeda point out how a considerable portion of the current debate on migration in Europe is characterized by metaphorical devices signifying "the fear of being overwhelmed with difference." (20I6, I8) Metaphors connected to water (such as 'flood,' 'tide,' 'wave,'stream,' 'tsunami' and so on) especially invoke the idea that an "unspecified European mainstream" could be wiped out if the threatening influx is not somehow controlled. (2016, I8) 
character. They are fueled by austerity, precariousness, anxiety, and fear, but they rely upon a deficit of historical information about Europe's colonial and imperial past. This means that the victims (and their descendants) of Europe's colonial crimes often know that bloody history far more intimately than the Europeans who appear to be doomed to reenact it. Historical information is thus more important than ever [...] (2016, XII-XIV)

Gilroy emphasizes the importance of a historically informed understanding of Europe's present in relation to the attitudes to, and the treatment of cultural and racial minorities. A failure to do so would result in a configuration of Europe as a racial and cultural homogeneity, heedless to the fact that "European identity has long included hierarchies and exclusions." (Passerini 2002, 205) The idea of Europe has always been predicated on difference and the unassimilable Other which is mobilized in order to establish internal cohesion and unity (Said I977; El-Tayeb 201 I). This is in line with how an understanding of Europe as 'cosmopolitan' rests on the renunciation of Europe's historical involvement in world domination, notably through colonialism, which has been instrumental in the formation of said cosmopolitan identity. (Bhambra 2015, I93) The dominant configuration of Europe thus relies on a certain historical erasure that does not acknowledge how deeply formative the colonial period was for the way in which the dominant cultural archive, in a European and national context, is still produced and enacted today. (Goldberg 2006; Said I977; Wekker 2016; Buikema 20I7; Ponzanesi \& Blaagaard 20II). The cultural archive is predicated on a construction of Otherness against which the positive self-conception of Europeanness could be formed.

This dominant configuration of Europe is always already a raced phenomenon. As David Theo Goldberg notes, race is central to the European self-conceptualization, even if European self-presentation has been predicated on a raceless ideal, a denial of race and with that, a denial 
of coloniality. ${ }^{7}$ I understand race and racialization in this context as a discursively produced phenomenon with material effects which determines one's (non)belonging to the rubric of Europeanness. Balibar has termed this "essentializing cultural difference" $(2005,4)$, the sociopolitical and spatial creation of Otherness. Hall notes that 'OOtherness' was from the beginning an invention of European ways of seeing and representing difference." $(2003,67)$ The figure of the Other is therefore a constant, even if unacknowledged phenomenon, a bordering practice through which the idea of Europe emerges. However, the way in which this otherness is imagined can shift over time and in different contexts. If Europe is Self, how does it construct its Other(s)? What "anxious politics" motivate this process, which "undergirds popular and political imagination across contemporary Europe”? (Modest \& de Koning 2016, 98)

In recent years, the figure of the Muslim has frequently been popularly discussed as a relatively new and ominous entity in the European space, specifically in the context of the migration crisis, an idea which can be easily challenged. For instance, following the dissolution of Yugoslavia in the early I990s, (Western) Europe had received a significant number of Muslim asylum seekers from Bosnia and Herzegovina and beyond, which did not prompt this exact response at the time. The more pronounced fear of Muslim migrants, grew after 9/I i in Europe and the West, sparking discussions of cultural incompatibility and introducing accompanying securitization measures. ${ }^{8}$ (Glynn 20I7) Yet,

7 Goldberg argues that Europe disavows its involvement in the colonialism and the subsequent colonial ordering of the world by singularly focusing on World War II as the height of racism and racial violence. World War II is recognized as a stain in the history of Europe, but is also singled out as a kind of aberration, without recognizing the link to colonialism (the mechanisms of colonial ordering were reinstated in warfare and the establishment of concentration camps). (2006, 336-337) By singularly highlighting the atrocities of World War II, there is no recognition of past racial transgressions (colonialism) nor of contemporary forms of racist violence (Islamophobia), nor attention to the link between all of them.

8 In that respect, consider the very recent remarks, made in November 2019 by French President Emmanuel Macron, who expressed concern over EU 
as Goldberg reminds us, "the contemporary euro-panics around 'the Muslim"' $(2006,363)$ have their roots in a much longer "rule of colonial difference." (2006, 36r) In present-day Europe, as it sees itself engulfed in the migration 'crisis,' the figure of the Muslim has not so much been replaced by the figure of the refugee-migrant as the cultural Other, as much as these two projections have become intertwined to signify not only cultural incompatibility but also a dangerous, violent and violating presence in the European realm. Anti-immigration and anti-Islam sentiments are frequently brought together in popular and political rhetoric. ${ }^{9}$ Together, these connotations configure the Muslim as a figure of "death approaching" (Goldberg 2006, 345) and therefore as the annihilation of Europe. This configuration, which signals absolute incompatibility, then legitimizes the various bordering practices that are created in the name of keeping Europe safe, secure and whole.

The presence of the racialized figure of the refugee-migrant in the European context in a certain sense signifies an abundance of meaning, for as Iain Chambers notes, "etched on the body of the contemporary migrant is not only the power of modern European law that regulates his or her status, frequently transforming their subjectivity into objects of "illegality," but also the inadvertent signature of a colonial past." (2013, I3) This has dire consequences for the actual subjects who are coded as refugees and/or migrants in the European context; as this

enlargement in the East, particularly focusing on the 'problem' of Bosnia and Herzegovina, which he signaled as a concern for the EU due to the supposed threat of returning jihadists, calling Bosnia a "ticking time-bomb," situated "right next to (the EU member) Croatia." (Associated Press 2019) Macron's statement reinstates the notion that Islam is a threat to Europe, and places this threat in the 'non-European,' semi-Orientalized space of Bosnia and Herzegovina.

9 Some notable examples are the Islamophobic reactions to the 2015/20I6 New Year's Eve sexual assaults in Cologne, Germany; the Polish conservative newspaper wSieci that featured a depiction of "The Islamic Rape of Europe" is frequently referenced in this context. But consider also, for instance, the explicit anti-immigration, anti-Muslim rhetoric by Dutch right-wing politician Geert Wilders, who famously spoke of "a tsunami of Islamization" threatening The Netherlands. 
imposed category 'sticks' to them (Ahmed 2004), it determines their social and physical mobility and their perception by the wider public. In the context of this dissertation, (forced) migration is not treated as merely a metaphor (symbolic dimension), since this would not sufficiently account for the lived experience of the migrating subject (personal dimension), and the way in which these groups and individuals respond to the various border processes (institutional dimension) that produce them as migrants and/or refugees. (Andrijašević 20I0, I6I) At the same time, the refugee-migrant as border figuration does represent a conceptual tool through which Europe's relationship to otherness can be assessed in a postcolonial context. Ponzanesi and Blaagaard express this well when they say that

The postcolonial approach is $[. .$.$] called into creating the$ connection between past legacies and current multicultural frictions in which the figure of the migrant (and also of the refugee and asylum seeker) becomes iconic for the changing configurations of Europe. (201 I, 5)

Taken as a border figuration, the figure of the refugee-migrant makes it possible to challenge the 'exceptionality' of the current discourse of European cultural and racial homogeneity by placing it in a larger, historically informed postcolonial dimension, evidenced particularly in Chapters I, 2 and 3 of this dissertation.

\section{The East/West Divide}

The second important element in my research on the discursive formation of Europe is the notion of a European East/West divide, according to which 'actual' Europe is imagined as "the Western heading." (Derrida I992, 25) Applying a postcolonial lens to the history of this idea highlights how the notion of Eastern Europe has been constructed according to a colonial logic of inferiority and Otherness (Wolff I994; 
Todorova [1997] 2009) but also how Eastern European nationalisms continue to be influenced by a perpetuation of (disavowed) imperial and racial attitudes (Imre 2014), even if they had never participated directly in the colonial project. Moreover, a postcolonial lens can account for the history of imperial and colonial rule in the Balkans, the Ottoman and Habsburg empires, which are actively obscured today by EU integration policies that enact historical erasure (Rexhepi 2018) in the name of Europeanization.

Larry Wolff's Inventing Eastern Europe (1994) explains how the notion of Europe as being divided by something called 'the West' and something else, lesser, namely 'the East,' came into being through the 18th century Enlightenment philosophy and rhetoric, and how this logic is still operative in how we think about Europe's internal division today. Moreover, Maria Todorova's Imagining the Balkans ([I997] 2009) zooms in on the specificity of the Balkan region in Eastern Europe as a particularly pathologized, backwards entity, supposedly corrupted by centuries of Ottoman rule, making this geopolitical area something of a cultural anomaly in a Europe primarily defined by Christianity, since the idea of Europe/the West was significantly shaped around the rejection of Islam and identification with Christianity (Hall 1992, I97) Both accounts, Wolff's and Todorova's, draw to some degree on Edward Said's Orientalism ${ }^{\text {Io }}$ (1978), which posits that the imperial West (the Occident) constructed its own image according to a projection of negative characteristics on the East (the Orient), emerging as the more civilized, elevated cultural entity. However, whereas in Said's analysis the Orient was located outside of Europe, creating a relatively straightforward idea about here and there, Eastern Europe and the Balkans in Wolff's and Todorova's works, respectively, are conceptualized as

Io Todorova has insisted on not conflating the discourse she calls Balkanism with Said's Orientalism, since, as she explains, there is an important difference between the two: Orientalism is predicated on a straightforward opposition (West-East; good-bad; civilized-barbaric), whereas the binary (or border) is more complicated in a Bakanist discourse. Balkanism speaks not of a simple opposition, but rather about an ambiguous belonging. 
culturally shunned intra-European entities; geographically close, but ideologically distant. Importantly, Said, Wolff and Todorova base their argument on a Foucauldian understanding of discourse in that they show how a certain reality is enacted through how it is imagined.

Thus, imperial and racial attitudes which informed ideas about European racial and cultural homogeneity were also projected onto intra-European spaces and cultures. Anikó Imre notes that "while civilization was firmly tied to the West, Eastern Europe shifted to an imaginary location somewhere between civilization and barbarism as the West's immediate and intermediary other." (2014, I 1 8) Other scholars, notably Milica Bakić-Hayden (1995), have shown how this inferiorization and pathologization of the East was subsequently internalized by Eastern European nations, who would in turn Orientalize their neighboring countries in an attempt to Europeanize themselves according to a Western model. Another way in which Eastern Europe approximates Europe proper is through the discourse of racial and cultural homogeneity which is predicated on racial exceptionalism/whiteness (Goldberg 2006; Imre 20I4, I3O), recently echoed in the political response to the 'Balkan corridor' migration route that ran through several countries in the Western Balkans, which I discuss in Chapter 3 of this dissertation.

What emerges from this reflection is the need for an expansion of the postcolonial lens towards the postsocialist historical and political realm; this way, it becomes possible to see how the idea of Europe has been shaped around a pathologization of the East this is steeped in colonial and Oriental discourses, and at the same time, this intersection allows us to consider how imperial and racial attitudes have been reproduced by Eastern European nations and projected onto either themselves or their other Others (the Roma, refugees, migrants) through a complex web of identification and disidentification, making it possible to think of the "racialization of the Balkans" as well as "racialization in the Balkans." (Baker 2018, 769) Moreover, a postcolonial understanding of the Balkans is especially pertinent in now, when the expansion of the EU is taking place in this region. The 'Europeanization' project of the EU integration politics is managed through a disavowal of colonial 
histories within the Balkan region, which legitimizes the erasure of larger European histories of imperialism, racism and conquest. (Rexhepi 2018, 943) Therefore, I specifically consider what possibilities emerge from thinking about the space of the Balkans as a border figuration in the European context. This border figuration should not be through of as innocent, but as productive: like the figure of the refugee-migrant, it is its ambiguous and liminal positioning in the European (imaginary) space that makes these border figurations useful to start unsettling a dominant configuration of Europe.

\section{Thinking Border Figurations Together}

So far, I have outlined how the figure of the refugee-migrant and the geopolitical area of the Balkans can be understood as liminal and possibly even corrupting entities in the dominant conceptualization of Europe that is built on principles of cultural/racial homogeneity and historical erasure. I have underscored the importance of applying a historical, postcolonial lens to these phenomena, which allows us to understand how they have been shaped by mutually constituting historical discourses that have their traces in colonialism and imperialism and that are enacted in racial discourses about European belonging in the 2 Ist century. These two border figurations represent potent discursive clusters in which the meaning of Europe has historically been negotiated, and have specific relevance for the present context.

The supposed exceptionality of the current migration crisis in Europe can be challenged by referring to the breakup of Yugoslavia of the early I990s, during and after which ex-Yugoslav nationals, mainly from Bosnia and Herzegovina, applied for asylum in Western Europe. (Glynn 2017) This was arguably an earlier 'refugee crisis' moment which challenged and impacted EU immigration policy (Barutciski 1994), but which is largely absent in current debates on migration in Europe. The Balkans, and the former Yugoslavia, represent contested terrain in Europe in relation to the eastward expansion of the EU also. At the 
moment of writing this Introduction, some former Yugoslav states are EU members (Slovenia, Croatia), some are candidate countries (North Macedonia, Montenegro, Serbia) and some are potential candidates only (Bosnia and Herzegovina, Kosovo). The expansion of the European Union in the Balkans has been taking place through 'Europeanizing' integration measures that rest on the disavowal of colonial and racist legacies of this region, performing a "postcolonial erasure" (Rexhepi 2018) that necessitates the consideration of these processes in a critical historical and postcolonial dimension. Furthermore, European borders are constantly being redrawn in this region as countries strive to implement EU integration requirements; the recent emergence and closure of the so-called 'Balkan route' or 'Balkan corridor' is illustrative of how "[ $t]$ he Balkans today are an integral part of Europe's so-called refugee crisis." (Bjelić 2018, 925) Studied together, the refugee-migrant and the Balkans as border figurations complicate any simple or straightforward idea of Europe or Europeanness, providing useful ground for interrogating bordering practices and erasures, spatial and symbolic, that are enacted in the name of Europe.

The centrality of the European migration 'crisis' in frequently highly charged political and popular discourse, not to mention the real effects of the European border apparatus on the migrating subjects themselves, means that it is necessary to think critically about how and why it is that the refugee-migrant occupies a central position in discourse, but a peripheral one in collective European spaces and imaginaries (the nation, society). Something similar may be said regarding the Balkans, and more specifically the region of the former Yugoslavia, which represents both a rejected, pathologized Other within Europe, as well as a space where Europe is unfolding and establishing itself. According to Balibar, Europe may "become possible again" only when it acknowledges

in the Balkan situation not a monstrosity grafted to its breast, a pathological "aftereffect" of underdevelopment or of communism, but rather an image and effect of its own history and will undertake to confront it and resolve it and thus to put itself into question and 
transform itself...[o]r else it will refuse to come to face-to-face with itself and will continue to treat the problem as an exterior obstacle to be overcome through exterior means, including colonization. (2004: 6)

Both the refugee-migrant as well as the Balkans represent disavowed subjects and spaces of ambivalence around and against which Europe is enacted. Both are "in" Europe, but not "of Europe" (Hall 2002, 57) and as such both are subjected to material and symbolic borders that uphold the European myth. The myth begins to unravel when these contradictory mechanisms are exposed, and when the constitutive outside is shown to be an integral (if rejected) element in European history and identity. Both reckoning and possibility, unraveling the myth prompts the question of whether Europe is possible otherwise, and what it may look like beyond its dominant silences, erasures and barriers.

For final note on thinking with border figurations, I draw once more on Balibar, who understands the border as a mobile figuration. In Europe at the Limits (2016, I66), he writes:

The question of borders is not the only one that affects European 'identity', European 'destiny' or European 'projects', but it is hardly separable from any of these (as a consequence, in particular, of globalization), and it is intimately articulated with historical limits. In each of the cases to which we can refer, it appears that borders have escaped the figure of linear demarcations more or less steadily inscribed in the territory by juridical and administrative means. They have become essentially mobile, and - as complex institutions themselves, which are contested from different sides - they extend their effects widely into the spaces that a conventional representation of Europe identified as 'internal' and 'external'.

The shift that (our conceptualizations about) borders are undergoing (from fairly static and straightforward to multiple and entangled), and 
that Balibar advocates for, is indicative for understanding belonging in/ and Europe in the context of this dissertation. Thinking through the border does away with simple dualisms (inside-outside; Self-Other; EastWest; migrant-citizen), and so the border represents a way to account for a more multiform social and political reality. This means that thinking through the border is not the same as applying or enforcing the border; it is an open rather than a closed process. This is further evidenced in Balibar's argument when he brings together events that at first glance may seem topically, geographically and politically divorced from each other: the 2014 uprising in Kiev, Ukraine, the 2013 shipwreck that resulted in hundreds of deaths in Lampedusa, Italy and the 2012 conflict in Damascus, Syria. These seemingly dispersed events are brought together under the heading of European limits; they occur at the geographical but also at the symbolic limits of Europe, away from the cultural and political nucleus, and therefore they seemingly do not carry as much weight as political conflicts and tragedies. However, particularly when considered together, they communicate something important not only about Europe's shifting border regimes, but also about "the representation of the 'Other' within Europe, and consequently Europe's self-definition.” (2016, I68) Thus, these 'peripheries,' when considered together, are more than the sum of their parts, more than a collection of dispersed struggles and catastrophes. Considered together, they are generative; holding up a mirror to the façade of a unified Europe by uncovering the limits of that configuration. In this dissertation, I too bring together actors and phenomena that are relegated to Europe's limits - the figure of the refugee-migrant and the region of the Balkans — in order to glean insight into Europe's self-definition vis-à-vis the (cultural) Other.

The border figuration is an expository agent, shedding light on parameters of nationhood, belonging and Europeanness in whose name the border is erected. More concretely, I use the concept of the border as a tool with which to expose and offer a critique of a dominant conceptualization of Europe (oftentimes predicated on colonialism, nationalism, whiteness, and a Western-coded understanding of civilizational progress). I also use the border as a way to trace the conditions of existence 
of those (individuals, populations, domains) who are subjected to the workings of the border apparatus. Through the notion of the border, I look at the processes of inclusion and exclusion as they occur in the European domain, spatially and discursively. These processes are mediated and mobilized by certain understandings of belonging, nationhood and 'proper' Europeanness in $2 \mathrm{I}^{\text {st }}$ century Europe. My highlighting of these constructs is a simultaneous critique of their workings by showcasing their inherent fallibility, alongside which I offer different forms of critique, in the form of artistic interventions and individual narratives that open up the question of Europe to alternative significations.

\section{METHODOLOGICAL REFLECTIONS}

\section{Analytical Scope and Approach}

The methodological makeup of this research is necessarily interdisciplinary, reflecting on the expansive array of themes and concepts that shape the five chapters making up this dissertation. I follow Sandro Mezzadra and Brett Neilson who, in Border as Method (2013, Io) state how they

question the limiting perspective imposed by the view that the breadth of research compromises its depth and rigor. Rather, we proceed with the commitment that breadth can produce depth, or better, produce a new kind of conceptual depth, "new ideas." [...] We seek to develop is a relational approach to the study of borders, one that remains politically responsive to the experiences of border crossing and border reinforcement and also adequate to the equivocations of definition, space, and function that mark the concept of the border itself. 
In their research, the border figuration functions both as epistemological device and as a methodological tool. Because there is no straightforward definition of the border (the border should be understood as situational, contextual and always shifting), there is no predetermined methodological toolkit with which the border, as method, can be applied onto situations and phenomena. Since the border is not neutral, neither is the data that emerges from methodologies that utilize the border approach. (2013, I7) The knowledge that results from such an approach should be understood as accountable, situated knowledge (Haraway 1989) that accumulates value from being critically embedded in specific historical and geopolitical contexts. Border research is therefore theoretically and methodologically broad, but precise in application, which translates into its analytical depth.

In my study of Europe, I consider specifically the positioning of the refugee-migrant and the Balkans in the construction of Europe. However, the data set I make use of is diverse; among other things, I analyze film, visual art and visual material, political discourses as well as political phenomena, interviews, experiential accounts, and even the (discursive) space of the airport. The broad range of data that is brought together in order to make sense of a complex phenomenon such as Europe echoes the interdisciplinarity of my approach, since I have used in my analyses insights from gender studies, postcolonial studies, postsocialist scholarship, critical border studies, cultural studies, poststructuralism, semiotics, psychoanalysis, ethnography, oral history, phenomenology, memory studies and visual studies. Teasing out specific methodological tools for each of these research traditions would not do justice to the research process, since the analytical approach I have taken in reference to these fields is more than the sum of its parts.

That said, the variety of the data as well as the variety of methodological approaches presented and employed in this research can be synthesized together under the more specific rubric of discourse analysis. I understand Europe to be a discursive formation that enacts particular realities and thus has material effects. Contextualizing Foucault's theory, Stuart Hall understands discourse not merely as a linguistic 
phenomenon but rather as the active practice of producing meaning and social realities through discursive formations. (I992, 29I). Thus, all of the material that features in my analyses can be understood to be discursive, because it produces meaning about Europe and (non-)belonging in a European context. Considered this way, spaces, texts, images, art and individual narratives are all discursive sites at which meaning (about Europe) can be enacted, negotiated and resisted.

\section{Principles of Discourse Analysis}

The discourse analysis that I employ here, following Foucault and Hall, is not predicated on a particular approach, tradition or school, and as such does not translate into a predetermined method. However, Rosalind Gill (2000, I88) gives a useful guiding principle for discourse analysis, namely:
A discourse analysis is a careful, close reading that moves between text and context to examine the context, organiza- tion and functions of discourse. [...] In the final analysis, a discourse analysis is an interpretation, warranted by detailed argument and attention to the material being studied.

What is significant here is the emphasis that a discourse analysis needs to place the study of its material in a wider (social, cultural, political, historical) context, as well as the fact that discourse analyses never (aim to) produce a final reading, but rather a situated, attentive and reading of the phenomenon in question. This principle is reflected in how the variety of the data in this dissertation is brought together under the heading of the two border figurations that I use as more specified discursive nodes through which the notion of Europe can be (re)thought.

Another guiding principle that informs the kind of discourse analysis I conduct here is the notion of intertextuality. Originally conceptualized by Julia Kristeva (I969), intertextuality points to the relationality 
between texts - that is, texts do not stand on their own but gain meaning by referring to other texts and contexts in a dynamic process of referral. What intertextuality proposes is "that we understand texts not as self-contained systems but as differential and historical, as traces and tracings of otherness, since they are shaped by the repetition and transformation of other textual structures." (Alfaro I996, 268) Others have contributed to the development of this concept, notably Foucault, who expanded the scope of intertextuality beyond the literary, textual realm to include social and political institutions. Moreover, Foucault adds to the principle of intertextuality a consideration of restrictions imposed by workings of power $(1972,224)$; in an intertextual dynamic, texts and discourses do not just simply refer to each other freely, but are bound by "existing networks of power, simultaneously creating and disciplining the text's ability to signify." (Alfaro 1996, 282) Conceptualized in this way, the principle of intertextuality is a key analytical tool which ties the rich data set that comprises this dissertation together under the discussion of belonging in/and Europe.

I apply the principle of intertextuality throughout the five chapters that comprise this dissertation. For instance, in Chapter 3 I look at how political discourses, and specific speech acts of European political leaders, reproduce the idea of the European East/West divide in the context of the migration route that was popularly known as the 'Balkan passage' or the 'Balkan corridor.' This is also evident in the fourth chapter, where I look at the plot and narrative of the Bosnian film 'Go West' that makes use of similar discursive tropes (progressive West and backwards East). Although the narrative of a (relatively obscure) film does not occupy the same ideological position as the speech acts of European national and EU leaders, an intertextual approach helps to explain how in these vastly different contexts a similar discourse about belonging in Europe is being produced. Discourse can thus be understood as an intertextual set of values, not tied to the medium to which they are expressed.

Discourse analysis in the Foucauldian tradition thus proves to be a suitable methodological approach to encompass the scope and aim of this research. Since the notion of discourse encompasses more than 
language alone, it makes it possible to trace how dominant configurations of Europe are enacted in institutional settings, political narratives and representations. Also, since discourse is never solely a top-down process, it is possible to consider how discourses are not only enforced, but also contested and even resisted in various domains: in individual narratives (Chapters I and 2), but also through the domain of visual art (Chapter 5). In that sense, discourse analysis makes it possible to consider how meaning is always under negotiation and thus never conclusive.

\section{Foregoing Linearity}

The dissertation is comprised of five chapters, four of which have been published and one that is in the process of being published. One is a journal issue, while the other four are contributions to edited volumes. Since they are all part of different publications, the chapters are presented here in a largely unedited form, conforming to the rules and style guidelines of each respective publication. That being said, I have chosen to present the chapters not in the order in which they were published, but according to a more thematic approach. Like I explained at the beginning of this Introduction, I am choosing to forego a chronological structure in order to highlight the fact that the argument I am presenting here is also a narrative in its own right; a story of contesting and negotiating belonging in contemporary Europe. This approach accompanies the analysis in that it allows me to, in the words of Rosi Braidotti, "fictionalize my theories, theorize my fictions [...] as a form of conceptual creativity." (20I I, 55) Moreover, this approach allows me to take authority over the work I present here without canonizing it: this is not another myth of Europe. Rather, a contestation of that myth emerges here through a scrutiny of its unstable foundations, through which a re-imagining of belonging in Europe can emerge. 
Works Cited

- Ahmed, Sara. 2004a. "Affective Economies." Social Text 2 2:2, I I 7- I39.

- Alfaro, María Jesús Martínez. I 996. "Intertextuality: Origins and Development of the Concept.” Atlantis I 8: I/2, 268-85.

- Anderson, Benedict. I991. Imagined Communities. Reflections on the Origin and Spread of Nationalism. London: Verso.

- Andrijašević, Rutvica. 2oro. "The International Organization for Migration and the international government of borders." Environment and Planning D: Society and Space 28, 977-999.

- Andrijašević, Rutvica. 20Io. "From Exception to Excess. Detention and Deportations across the Mediterranean Space." The Deportation Regime. Sovereignty, Space and The Freedom of Movement, eds. Nicholas de Genova and Nathalie Peutz. Duke University Press, Durham \& London, I47- I65.

- Anzaldúa, Gloria. I 987 . Borderlands/La frontera. The New Mestiza. San Francisco, Aunt Lute Books.

- Associated Press. November 20 19. "Bosnia Outraged After Macron Calls It a 'Ticking Time-Bomb”' New York Times, 7 November 20 1 9. https://www. nytimes.com/aponline/2019/I I/o7/world/europe/ap-eu-bosnia-macron.html

- Baker, Catherine. "Postcoloniality Without Race? Racial Exceptionalism and Southeast European Cultural Studies." Interventions 20: 6, 20 I 8, 759-784.

- Bakić-Hayden, Milica. I 995. "Nesting Orientalisms: The Case of Former Yugoslavia," Slavic Review 54: 4, 9I 7-3 I.

- Balibar, Étienne. 2002. "What is a Border?" Politics and the Other Scene, 75-86. London, New York: Verso.

- Balibar, Étienne. 2004. "At the Borders of Europe." We, the People of Europe? Reflections on Transnational Citizenship, trans. James Swenson, I - Io. Princeton University Press.

- Balibar, Étienne. 2005. "La construction du racism" - "The Construction of Racism." Actuel Marx, 2: 38, I I - 28.

- Balibar, Étienne. 2009. "Europe as Borderland." Environment and Planning D: Society and Space, 27, I90-2 I 5.

- Balibar, Étienne. 2016a. "Europe at the Limits." Interventions I 8:2, I65- I 7 I.

- Barutciski, Michael. I 994. "EU States and the Refugee Crisis in the Former Yugoslavia" Refuge 14:3, 32-35.

- Bhambra, Gurminder K. 2016a. "Whither Europe?" Interventions I 8:2, I $87-202$.

- Bjelić, I. Dušan. 20r 8. "Toward a Genealogy of the Balkan Discourses on Race.” Interventions, 20:6, 906-929.

- Bjelić, I. Dušan. 20 1 8. "Introduction." Interventions, 20:6, 75 I-758.

- Bracke, Sarah; de Jong, Sara; Koevoets, Sanne; van Leeuwen, Fleur; Oldersma, Jantine. 20 I 4a. "Editorial Crossing Gendered Borders." Tijdschrift Voor Genderstudies 17:3, 201-209. 
- Braidotti, Rosi. 2o I r. Nomadic Subjects. Embodiment and Sexual Difference in Contemporary Feminist Theory, 2nd edition, New York: Columbia University Press.

- Butler, Judith. Bodies That Matter. On the Discursive Limits of 'Sex'. London/ New York: Routledge, I 993.

- Buikema, Rosemarie. 2020. Revoltes in Cultural Critique. Rowman \& Littlefield International.

- Chambers, Iain. 20 I 7. Postcolonial Interruptions, Unauthorised Modernities. Rowman \& Littlefield International.

- Chouliaraki, Lilie. 201 7. "Symbolic Bordering: The Self-Representaton of Migrants and Refugees in Digital News." Popular Communication I 5:2, $78-94$

- Dainotto, Roberto M. 2007. Europe (In Theory). Duke University Press, Durham and London.

- Derrida, Jacques. I 992. The Other Heading. Blooming- ton: Indiana University Press.

- El-Tayeb, Fatima. 20 I r. European Others: Queering Ethnicity in Postnational Europe. Minneapolis: University of Minnesota Press.

— Foucault, Michel. I972 (1971). “The Discourse on Language.” The Archeology of Knowledge and the Discourse on Language. Trans A.M. Sheridan Smith. New York: Harper \& Row, 2 I 5-37.

- Foucault, Michel. I980. Power/Knowledge. Brighton: Harvester.

— Gill, Rosalind. 2000. "Discourse Analysis." Qualitative Researching with Text, Image and Sound: A Practical Handbook, eds. Bauer, Martin, \& Gaskell. London: Sage, I72- r 90 .

- Gilroy, Paul. 20r6. "Foreword: Europe Otherwise." Postcolonial Transitions in Europe: Frontiers of the Political, eds. Ponzanesi \& Colpani. US: Rowman \& Littlefield International, xi-xxv.

- Glynn, Irial. 20I 7 "How the spectre of Yugoslavia looms over EU's Handling of the Refugee Crisis." The Conversation. Accessed I 2 November 2019. http:// theconversation.com/how-the-spectre-of-yugoslavia-looms-over-eus-handling-of-the-refugee-crisis-79393

- Goldberg, David Theo. 2006. "Racial Europeanization.” Ethnic and Racial Studies 29:2, 33 I-364.

- Gržinić, Marina. 2007a. "Linking Theory, Politics and Art." Third Text 2 I:2, 199-206.

- Hall, Stuart. I992. "The West and the Rest: Discourse and Power." Formations of Modernity, eds. Hall \& Gieben. Polity Press in Association with the Open University, Cambridge, England, I 85-227.

- Hall, Stuart. 2002/2003. "'In, but not of Europe.' Europe and its Myths." Soundings 22, 57-69.

- Hall, Stuart; Evans, Jessica; Nixon, Sean. 2013. Representation. Cultural Representations and Signifying Practices. Sage Publications Ltd. 
- Haraway, Donna. 1988. "Situated Knowledges: The Science Question in Feminism and the Privilege of Partial Perspective.” Feminist Studies, I 4:3, 575-599.

- Hesse-Biber, Sharlene Nagy. 201 3. Feminist Research Practice. A Primer. Sage Publications, Inc.

- Holmes, Seth M. \& Castańeda, Heide. 20r6. "Representing the "European Refugee Crisis" in Germany and Beyond: Deservingness and Difference, Life and Death." American Ethnologist, 43: I, I 2-24.

- Imre, Anikó. 2014. "Postcolonial Media Studies in Postsocialist Europe." boundary 2, II $3-\mathrm{I} 34$.

- Irigaray, Luce. I 985. An Ethics of Sexual Difference. Ithaca: Cornell University Press.

— Kristeva, Julia. “Word, Dialogue and Novel.” Sèméiotikè: Recherches pour une Sémanalyse: I 82-250. Paris: Éditions du Seuil.

- Kristeva, Julia, and Leon S. Roudiez. I 982. Powers of horror: An Essay on Abjection. New York: Columbia University Press.

- Louw, Eric P. 200r. "The Limits of Power: Resisting Dominant Meanings.” The Media and Cultural Production. London: Sage Publications, 205-2 I4.

- Mezzadra, Sandro \& Neilson, Brett. 2013. Border as Method. Or, The Multiplication of Labor. Duke University Press, Durham and London.

- Modest, Wayne and Anouk Koning. 20r6a. "Anxious Politics in the European City: An Introduction.” Patterns of Prejudice, 50:2, 97- 108.

- Navickaite, Rasa. 20r 4a. "Postcolonial Queer Critique in Post-Communist Europe - Stuck in the Western Progress Narrative?” Tijdschrift Voor Genderstudies I 7:2, I65-I85.

- Passerini, Luisa. 2002. "From the Ironies of Identity to the Identities of Irony." The Idea of Europe: from Antiquity to the European Union, ed. A. Pagden. Washington, DC: Woodrow Wilson Center Press \& Cambridge: University Press, i 9I-208.

- Ponzanesi, Sandra. 2016a. "The Point of Europe: Postcolonial Entanglements. "Interventions I 8:2, I 59- I64.

- Ponzanesi, Sandra and Bolette B. Blaagaard. 2o r r. "In the Name of Europe." Social Identities I 7: I, I - Io.

- Ponzanesi, Sandra \& Colpani, Gianmaria. 201 5. Postcolonial Transitions in Europe. Frontiers of the Political. US: Rowman \& Littlefield International.

- Portelli, Alessandro. I 998. “Oral History as Genre.” Narrative E Genre. Routledge, 23-45.

- Rexhepi, Piro. 201 8. “The Politics of Postcolonial Erasure in Sarajevo.” Interventions, 20:6, 930-945.

- Rose, Gillian. 2001. Visual Methodologies an Introduction to the Interpretation of Visual Materials. SAGE Publications London, Thousand Oaks, New Delhi.

- Rumford, Chris. 20 1 2. "Towards a Multiperspectival Study of Borders." Geopolitics I 7:4, 887-902.

- Said, Edward W. r 978 . Orientalism. New York: Pantheon Books. 
- Scott, Joan W. I986a. "Gender: A Useful Category of Historical Analysis." The American Historical Review 91:5, I053- 1075.

- Spivak Gayatri Chakravorty. I976. "Translator's preface.” Of Grammatology, ed. J. Derrida. The Johns Hopkins University Press, Baltimore, MD, ix-lxxxvii.

- Sultana, Farhana. 2007. "Reflexivity, positionality and participatory ethics: Negotiating Fieldwork Dilemmas in International Research." ACME, 6:3, $374-385$.

- Todorova, Maria. [r 997] 2009. Imagining the Balkans. New York: Oxford University Press. 2nd Edition.

— Trakilović, Milica. 2016. "Passing through: Negotiating Identity, Sexuality and Movement in Ahmed Imamović’s Go West.” Transnational Cinemas 7:2, I 83 - I 95 .

— Trakilović, Milica. 2016. "The Other Within”: Challenging Borders from the European Periphery." Postcolonial Transitions in Europe. Contexts, Practices and Politics, eds. Sandra Ponzanesi \& Gianmaria Colpani. Rowman \& Littlefield International, 209-228.

- Trakilović, Milica. 201 9. "Bodies Making Spaces: Understanding the Airport as a Site of Dissonance." Dissonant Heritages and Memories in Contemporary Europe, eds. Lähdesmäki, Passerini, Kaasik-Krogerus छ van Huis. Palgrave Macmillan, I37- I56.

- Trakilović, Milica. 20 1 9. "'On this Path to Europe” - The Symbolic role of the 'Balkan Corridor' in the European Migration Debate." Cultures, Citizenship and Human Rights, eds. Buikema, Buyse E Robben. Routledge.

— Trakilović, Milica. Forthcoming 2020. "Between "Fleeing" and "Taking Flight": Negotiating the Refugee Label." The Mobility of Memory across European Borders: Migrations and Diasporas in Europe and Beyond, eds. Passerini, Trakilovic \& Proglio. Berghahn Books, New York.

- Walters, William. 2002. "Mapping Schengenland: denaturalizing the border." Environment and Planning D: Society and Space, 20, $56 \mathrm{I}-580$.

- Wekker, Gloria. 2006. "No Tide, No Tamara/Not Today, Not Tomorrow: Misi Juliette Cumming's Life History." The Politics of Passion. Women's Sexual Culture in the Afro-Surinamese Diaspora. New York: Columbia University Press, I -55 .

- Wekker, Gloria. 2016. White Innocence. Paradoxes of Colonialism and Race. Durham, NC: Duke University Press.

- Whitley, Leila Maire. 20 I 5. More than a Line: Borders as Embodied States. Doctoral thesis, Goldsmiths, University of London.

- Wolff, Larry. I 994. Inventing Eastern Europe. The Map of Civilization on the Mind of the Enlightenment. Stanford University Press. 

Part II -

Articles 


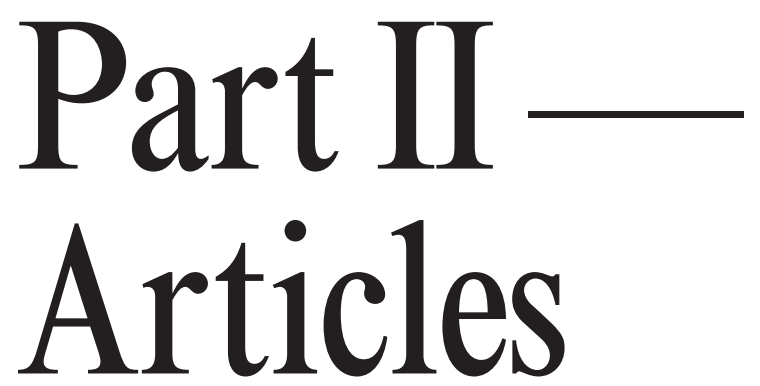

\section{ARTICLE 1}

\section{Bodies Making Spaces: Understanding the Airport as a Site of Dissonance}

Published as part of the edited volume Dissonant Heritages and

Memories in Contemporary Europe (eds. Lähdesmäki, Passerini, Kaasik-Krogerus \& van Huis). Palgrave Macmillan, 2019

\section{Introduction}

Amsterdam Airport Schiphol in the Netherlands is a veritable hub of networks, contact zones, and transfers. Boasting the title of third-largest airport in Europe in terms of number of passengers, it now processes approximately 60 million passengers yearly. Schiphol wants to be known for four intersecting qualities, being "efficient, reliable, sustainable and inspiring" (Amsterdam Airport Schiphol). As a frequent flyer in and out Schiphol myself, I can attest to its fulfilling these aims: I always marvel at the speed and ease with which I am able to move through the airport, whether on my way to a gate or back from a trip. While going through many airports is a chore, being at Schiphol is almost a treat; 
as I effortlessly move from one section to the next, I am entertained by colorful and inviting shop displays, art objects, and informational posters and notices. Although this warm reception is part of Schiphol's aim to "provide smooth processes and good facilities and [do] everything in its power to guarantee its passengers a pleasant journey" and "to remain the preferred airport in Europe," (ibid.) my experience is not a universal one. Indeed, Schiphol, like all airports, is very much a site of (invisible) border zones that will allow easy entry to some subjects, while prohibiting free movement to others.

In January of 2017 , I spoke to a young Syrian who had come to the Netherlands in 2015, seeking asylum. More specifically, his place of arrival was Schiphol, but his experience of the place differed drastically from mine. While I routinely experience almost uninterrupted movement in this large and seemingly open space, my interviewee's ${ }^{\text {II }}$ stay at Schiphol was characterized by waiting and confinement. After introducing himself as a refugee to the Schiphol police, he spent seven days in the Schiphol detention center while waiting for his request for asylum to be processed. During this time, his movement was severely restricted; he describes the detention center as a "good prison," but a prison nevertheless. I take this personal account as the empirical starting point of my analysis, which will center on a phenomenological reading of the space of Schiphol Airport. I thereby join several other contributors to this book who have chosen to analyze particular spaces as sites of heritage dissonance, notably Iris van Huis and Sigrid KaasikKrogerus. In my analysis, Schiphol also emerges as a site of heritage dissonance.

Theorizing on the possibility of queering social spaces through the arrival of different bodies, Sara Ahmed writes that "the skin of the social might be affected by the comings and goings of different bodies, creating new lines and textures in the ways in which things are arranged." (2006, 9) At the same time, as Anssi Paasi notes, spaces are constantly being

I I The interview was conducted in the context of the ERC project Bodies Across Borders in Europe: Oral and Visual Memory in Europe and Beyond on I4 January 2017 in Amsterdam, the Netherlands. 
reworked and reconstructed based on unequal and hierarchical power relations, "in the sense that some actors are more actively participating in the production of space/scale while most people are 'consuming' and reproducing them.” (200I, I3) In this chapter, I consider how the controlled movement of bodies in airports contributes to, and contests, both the European memory-heritage-identity complex (Macdonald 2015, 5) and the (Dutch) cultural archive (Wekker 20I6). The former concept is useful in this analysis because it allows for an exploration of the airport as a historically, culturally, and politically entangled phenomenon, while the latter specifically addresses the ways in which the Dutch cultural canon, to which Schiphol belongs in my analysis, is built on an imperial and colonial legacy. I will provide a phenomenological account of Schiphol Airport based on my interviewee's experience of arriving in the Netherlands as a Syrian national and applying for asylum. In the process, I am guided by the following question: To what extent are European cultural and national politics of belonging being promoted and enforced at airports in general, and Schiphol Airport in particular, through processes of detainment and control, and to what extent does Schiphol emerge as a site of heritage dissonance through this dynamic?

\section{Methodological framework and conceptual approach}

\section{SPACE AND BELONGING}

In this chapter, I ask how spatiality and belonging are negotiated at the airport and how they impact on identity formation. At the same time, in no way do I want to produce a unitary, simplified, or homogenous conceptualization of identity, or any conceptual category for that matter. In her chapter in this volume, Tuuli Lähdesmaki has noted that identity has become a rather weak analytical category, and instead proposes the concept of belonging, as that indicates a process rather than a fixed position. I join her in this approach, particularly drawing on Marco Antonisch's (2010, 645) argument that any analysis of belonging should contain considerations both of personal feelings of being 
"at home" (or not) somewhere and of the broader discursive dimension that "constructs" belonging according to a particular social and spatial ordering, and in so doing produces a "politics of belonging". My analysis of Schiphol consists precisely of these two dimensions. My interviewee's embodied experience of arriving at Schiphol and being detained represents the first set of empirical data and the starting point of my analysis. From there, I extend the analysis to a broader observation of Schiphol's spatial ordering, which includes Schiphol's camp-like detention center and the "open" space of the airport. With the latter, I pay particular attention to how certain objects, visuals, and discourses are disseminated, and what kind of politics of belonging is attached to them. I am informed by Benedict Anderson's formulation of the nation as an imagined community that rests in the imagined union of its national subjects $(2006,7)$, as well as Anthony Easthope's insistence that nations exist in their discursive dimensions (I999, IIX). All of this suggests that cultural and national identities are performative rather than absolute, which also means that I am less interested in pinpointing what a national space may be and more in how it is brought into being, i.e. what cultural, organizational, and ideological practices are at the heart of these conceptualizations. That being said, in this analysis I do understand Schiphol Airport as a specifically European space according to a critical postcolonial/decolonial scholarly framework.

To think about spaces is to think about the kinds of bodies that can inhabit them. In other words, the question of spatiality is largely a question of bodily presence. In this chapter, I take a phenomenological approach in looking at the connection between spaces and bodies, which means that I am interested in actual bodily practices that make up somebody's being-in-the-world and the inevitable affective experiences that accompany these. I agree with Sharon Macdonald when she says that:

Giving attention to materialities not only recognizes the inevitably material nature of human existence but also opens up investigation of how the differential properties of particular 
materials, objects or technologies interact with human endeavour and understanding; in other words, what difference do the differences between things make? $(2015,84)$

Indeed, what difference do the differences between bodies and the way that they are positioned in space make? First of all, it is important to note how spatiality and understandings of belonging are and have always been inextricably linked. As Anssi Paasi observes: "Identity is not merely an individual or social category, but also — crucially - a spatial category, since the ideas of territory, self and 'us' all require symbolic, socio-cultural and/or physical dividing lines with the Other." (200I, Io) Paasi here not only points to the importance of recognizing the spatial and territorial logic of identity formation, but also its inherent hierarchical ordering. Since "space" (as a concept and a physical structure) can only exist if it is in some way delineated or defined, then it follows that identities require boundaries as well, if they are to be comprehensible, "readable." In this chapter, drawing on the conceptual work by Sara Ahmed in Queer Phenomenology (2006) and A Phenomenology of Whiteness (2007), I am taking a phenomenological approach by looking at how a spatial makeup and the controlled movement of bodies in spaces (airports in particular) bring into being and enforce dominant notions of national and cultural heritage, keeping in mind how these may be contested as well.

\section{EUROPE AND RACE}

Many scholars have made the link between a European claim to colorblindness (notably El-Tayeb 20II, Goldberg 2006, and Wekker 20I6) and the dominant conception of spaces as (culturally, politically, and ideologically) "white”. As Fatima El-Tayeb states in European Others:

To reference race as native to contemporary European thought, however, violates the powerful narrative of Europe as a colorblind continent, largely untouched by the devastating ideology it exported all over the world. This narrative, framing the 
continent as a space free of 'race' (and, by implication, racism), is not only central to the way Europeans perceive themselves, but also has gained near-global acceptance (201 I, Xv).

El-Tayeb here speaks of the way in which European spaces have been imagined, and of the dominant cultural and symbolic framings and perceptions which have followed from the idea that Europe is a continent that is not influenced or "touched" by race. Theo Goldberg points out how, in order to maintain this ideal of a racially homogenous space, Europe has historically purged its territories from those considered non-white and/or non-European, both in a symbolic and in a literal sense, "repeatedly making the Different different so as to sustain the Same" (20II, 357). El-Tayeb joins him in this line of thought by illustrating how "Europeans possessing the (visual) markers of Otherness" will always stand outside of a conceptualization of European authenticity and thus will always carry the notion of "arrival" with them, even if they belong to the descendants of migrants who arrived to Europe decades before (20Ir: xxv). This reinforces the racialized idea that there is a "proper Europeanness" (E1-Tayeb 20I I, xii), but the exclusionary logic on which this notion is built is difficult to critique or even point out.

Gloria Wekker comes to a similar conclusion with regards to the question of a racialized cultural identity in the Netherlands. She argues that identifying the "whiteness" of the dominant conception of Dutchness is "iconoclastic" (Wekker 2016, 2), because the racialized logic that is the foundation of this self-conception is completely disavowed. This dominant idea is part of the Dutch cultural archive, "an unacknowledged reservoir of knowledge and affects based on four hundred years of Dutch imperial rule" (ibid.) that informs the processes of making meaning on all levels (individual, institutional and structural/ symbolic). The cultural archive for Wekker is not located in any particular place, but it does inform behaviors, rules, knowledge, and emotions because it works as "a repository of memory, in the heads and hearts of people," (2016, I9) and thus also inevitably influences the spatial 
ordering of bodies and objects.

Wekker's notion of the cultural archive as a highly elaborate system in some respects echoes Sharon Macdonald's theory of the European memory complex, which she in fact points out is better referred to as "the memory-heritage-identity complex" $(2015,5)$. Both concepts point to the interrelation between the workings of memory, the construction of belonging, and the preservation and building of heritage sites/spaces where memory and identity come together. In fact, both Wekker and Macdonald emphasize the foundational importance in the European imaginary of World War II and the centrality of the Holocaust "as the epitome and model of racist transgressions" (Wekker 2016, 4), resulting in the cosmopolization of the memory of the Holocaust in Europe and beyond as well (Macdonald 2015, 2 I4). The centrality of the Holocaust in European memory is also responsible for a "displacement" of European colonialism "off” the European shores and from European historical consciousness, which invokes the notion of Europe as a separate space free of racism all the more (Wekker 2or6, 4). Theo Goldberg notes how the Holocaust serves as a reference point in the European imaginary which results in a "racial erasure" and an "evaporation" of colonial history from European shores $(2006,336)$. Both the (Dutch) cultural archive and the (European) memory complex are heavily informed by this historical moment.

All of these accounts are not meant to contribute to a homogenization of "European space," nor to imply that the Dutch cultural archive and the European memory complex are interchangeable and easily comprehensible phenomena. Highlighting the similarities between these concepts, however, should contribute to a deeper understanding of the place (and displacement) of racial minorities in the European imaginary, as well as that of actual European spaces. Theo Goldberg's concepts of racial europeanization and racial regionalization are of central importance here. While racial europeanization signifies the particular ways in which race is being done in Europe (the centrality of the Holocaust and the subsequent erasure of race being a prime example), racial regionalizations "exemplify the regionally prompted, parametered, 
and promoted racisms in the form of 'racial europeanization"'(Goldberg 20I I, 333). What this means is that distinct local characteristics still contribute to the overall idea of racial europeanization, keeping the idea of Europe as a racially "pure" territory in place, and hence it makes sense to see how the particular situation of the Netherlands fits into a larger European framework. Sharon Macdonald, in her ruminations on Europe as a memoryland, or rather memorylands, arrives at similar conclusions: "The indeterminacy of the singular or plural here is indicative of what is at issue" $(2015,2)$. Macdonald recognizes that there is an overarching, although by no means unvarying way of understanding and doing the past in Europe, while there are also significant variations on more local levels (ibid.). This tension between the national and the European can also be found at airports, as they are complex sites where European and national (Dutch) heritage are simultaneously enforced and contested. When talking about heritage, I am drawing on Visnja Kisić's conceptualization of "heritage dissonance," noting that the meaning of heritage is always contingent and never stable, since dissonance is always present as "a passive potential." (2017, 29.) Considering Schiphol as a site of dissonant heritage is useful since, as, according to Kisić, heritage is both a unifier and a simultaneous producer of difference, respectively represented in my argument by the airport and its detention center. It is important to note, however, that dissonance does not always stand for contradiction, but can also point to the instability and negotiation of political processes and power relations $(2017,57)$.

\section{BORDERING PROCESSES}

European understandings of national belonging have been significantly influenced by the irregular migration that has marked the beginning of the 2 Ist century, acquiring a particularly central position in popular and political debates since the European migration/refugee crisis at the beginning of 2015. As Henk van Houtum (2010, 960) observes, anxieties around all three going hand in hand. They especially operate in today's EU (which is popularly and routinely collapsed into Europe), where the openness of its internal borders - according to the Schengen principle, 
at least, although this openness has been modified in light of the migration crisis and become more controlled - is counteracted by fortifying its external borders. The rise of, and support for, right-wing populism across Europe reflects the wish to keep unwanted others at bay and fortify outer boundaries which are perceived as having been weakened and being in dire need of restoring, which the Brexit phenomenon is an exemplary case of. Anssi Paasi (200I, 22) has noted that, out of all the continents, Europe is the youngest in the sense that European national boundaries have been collapsed, redrawn, and reworked the most in the past century. In Europe, national and ethnic belonging typically carry much more weight in how subjects identify themselves than a broader and perhaps more elusive European identity, resulting in differing accounts and opinions about what exactly constitutes that identity (Paasi $200 I, 2 \mathrm{I})$. Yet it can be argued that it is precisely because there is no official account of what constitutes Europe that the idea of a singular European identity has emerged so strongly in recent years, clearly outlined against the constant "threat" of migration.

Indeed, in Memorylands, Sharon McDonald (2015, 37) discusses European histories and observes that identity-building is often predicated on invoking an "oppositional 'Other," especially the Muslim Other $^{\mathrm{r} 2}$, through different mechanisms of exclusion that can take various shapes: social, cultural, political, structural. In White Innocence, Gloria Wekker highlights "the fundamental impossibility of being both European, constructed to mean being white and Christian, and being black-migrant-Muslim-refugee" (2016: 2r). Protecting the European space thus becomes synonymous with protecting an imagined European identity by erecting "a myriad of new invisible borders that are ideological, radicalized and politicized" (Ponzanesi and Blaagaard 20I I, 3). This means that the process of monitoring, controlling, and surveilling those who are deemed as outsiders extends far beyond the official national and geographic borders zones into "diverging social practices and discourses"

I 2 The figure of the Muslim especially carries with it a threat of death (Goldberg 2006, 345) and therefore inspires particularly high levels of apprehension and fear in the post-9/I i moment. 
(Paasi 200I, I6). In other words, invisible bordering practices, propagated and upheld by social and structural actors and institutions, are just as instrumental as visible, official mechanisms of border control in producing the kind of segregation that makes it possible to speak and think of Europeanness as a solid and unquestioned project. Official bordering practices interact with invisible borders as ideological parameters and come together in the complex site of the airport.

Processes of bordering are considered in this chapter in their ideological dimension, as something that is actively being done rather than something that simply is. Considering them in their processual dimension moves us to an understanding of borders not as spaces marked on a map, or onto territory, but instead as "actions that must be performed by human beings in relation to one another. Borders can be made to exist, and must be made in order to exist" (Whitley 2015, I4). Conceptualizing borders not according to what they are but according to how they are being done, which is a change in understanding borders not as ontology but as function (ibid. I6), allows me to trace the processes of inclusion/exclusion at Schiphol Airport which need to be actively maintained in order to sustain a particular notion of cultural/ national homogeneity. At the same time, understanding the processual logic of borders might even allow for a conceptualization of practices that challenge their exclusionary nature.

POLITICS OF THE AIRPORT

Airports not (only) figure not as zones of transit, they also fulfil a political role. By looking at Amsterdam's Schiphol Airport specifically, I consider how this space represents a site of a specific and enforced notion of cultural heritage, a notion which is also always contested and under threat. While my observations could be extended to a broader analysis of airports as (European) cultural archives, I am following Sharon Macdonald's $(2015,6)$ "assemblage theory" approach of studying specific sites of knowledge and identity production so as to avoid generalizations and notice context specificities. This allows me to consider Schiphol Airport as a site where, first and foremost, the notion of the 
Dutch cultural archive is enforced, negotiated, and contested in a complex way, while Goldberg's conceptualization of racial Europeanization and racial regionalization allows me to still place these observations into a larger European framework and connect it to Macdonald's memory-heritage-identity complex.

I follow Debbie Lisle, who advocates for politicizing the airport as a site of "mediated power" $(2003,4)$. Understanding the airport as mediated means paying particular attention to how power relations there are always being negotiated, destabilized, challenged, and subverted. This Foucauldian strand of thinking allows us to see how an airport is never merely the site of extreme authority, control, and surveillance (although it is of course all of these things too). Rather, understanding power as mediated in airports makes it possible to consider how they are also sites of continually contested meanings, and this in turn allows me to see how the notion of cultural heritage and the practice of bordering take form and are challenged at this site. The point is that power, just like people, "never stays put at airports." (ibid.) At an airport, the border is, in Balibar's words (2002, 8I), "polysemic" in the sense that it does not

have the same meaning for everyone, and indeed this differential meaning is essential to the function of the border [... Border law enables some to pass national frontiers, while denying others; it upholds the freedom of circulation of some, while depriving others of this same freedom (Whitley 2015, I7).

Airports as border sites have different meanings for different people and also actively work to produce those meanings: they can be sites of both national belonging and forced alienation. Although my own reading of Schiphol Airport pays more attention to the way in which power is used to control, monitor, and detain unwelcome bodies, as a tool of cultural hegemony, it is important to keep in mind how and where these mechanisms fail to exert their control. In what follows, I provide a phenomenological analysis of the airport, starting with my interviewee's experiential account. 


\section{Phenomenology of the airport}

\section{PERIPHERAL IMAGINARIES}

In January 2017, I interviewed a young Syrian who recounted his journey coming to the Netherlands, and I draw here on his experiential account of arriving at Schiphol as an asylum seeker. As he had been working in Dubai for years before his departure, he describes his trajectory in light, easy terms, saying how he and the friend who was accompanying him were "laughing all the way." However, upon their arrival at Schiphol Airport, they spent an hour in front of the police office, paralyzed by the idea that they would have to introduce themselves as asylum seekers: "You know, your pride cannot allow you to say 'We're asking for asylum." I would like to consider the disorienting experience that occurs once a request for asylum is uttered, and how this disorientation takes place on a discursive and phenomenological level. In other words, I am looking at where the category of asylum seeker or refugee places one in the social and cultural European fabric, but also at what it means spatially to move from traveller to asylum seeker; in this case, my interviewee was literally removed from the "open" ${ }^{\text {x3 }}$ space of the airport into the closed space of the Schiphol detention center, where he spent seven days while waiting for his case to be processed. He was removed from the airport the moment he "became" an asylum seeker; this social category precluded him from inhabiting the same cultural space as other travellers. Of course, this was done according to the official asylum procedure $^{\mathrm{I} 4}$ in the Netherlands, but in this analysis I am more interested

13 I am aware that classifying airports as 'open' is somewhat of an oxymoron, especially considering how airports are becoming sites of ever more sophisticated mechanisms of surveillance, control, and restricted movement. However, in this case I contrast the relative openness of Schiphol Airport (mainly designed to facilitate travel) with the containment that characterizes the Schiphol detention center, where movement is controlled and restricted to a very high degree.

I 4 One can apply for asylum at a Dutch border by reporting to the Immigration and Naturalization Service (IND). In case the person who is applying for asylum is arriving by either plane or boat from a non-Schengen zone, they are detained and must apply for asylum immediately, before crossing the external 
in the symbolic and cultural dimension of these bordering practices. He was not taken to the detention center prior to his request. In other words, there was nothing in particular about his physical appearance that coded him as somebody seeking asylum. Rather, it was the utterance of the request that marked his body as one that should be removed from the premises of the open airport zone. The airport emerges in this case not as a site of empty signification, but very much as a national and even European space in which anxieties surrounding the collapse of cultural homogeneity routinely result in the removing and containment of undesirable bodies from public spaces, an ideology which I have already outlined above with the discussion of El-Tayeb, Wekker, Macdonald, and Goldberg. The asylum seeker in this case comes into being through a discursive (verbalizing the need for asylum) and spatial dimension (being removed from the airport to the airport detention center).

Mark Salter (2006, I68) has noted that the global passport and visa regime is built on a confessionary logic that urges subjects to willingly present their bodies and data for scrutiny in order to be granted mobility. In this particular case, the confession is quite literal, since it is not stored in document but in a verbalization. Both the airport and the detention center function as spaces with particular meanings: the airport is a space of transit because it is (presumably) made up by travellers, while, conversely, the detention center is a space of (temporary) confinement because it is inhabited by asylum seekers/migrants/refugees. ${ }^{\text {I5 }}$ As Sara Ahmed points out in Phenomenology of Whiteness, "likeness is as an effect of the proximity of shared residence" (201 I, I55). Spaces are coded in a certain way by the kind of bodies that (are allowed to) inhabit them. There

(Schengen) Dutch border, at the Application Centre of Schiphol Amsterdam airport (Aanmeldcentrum Schiphol, AC). The person arriving at Schiphol Airport will in most cases be detained by the Royal Military police. As those who are detained at Schiphol are not officially on Dutch territory, they can be expelled should their application be rejected. (Ammeraal, Broekhof and van Kamen 2014, 7; 22.)

I 5 I do not mean to suggest that the terms migrant, refugee, and asylum seeker are interchangeable, but I cluster them together here to point to the classification of "undesirable others" in light of the $20{ }_{5}$ European migration crisis. 
is nothing intrinsically or fundamentally similar about these bodies, but it is their (forced) proximity that creates a certain kind of reading of that space. Accordingly, the Schiphol detention center is a place of detention because it is inhabited by people coded as asylum seekers, while Schiphol Airport is a place of transit because it is inhabited by presumably cosmopolitan (inter)national subjects. The movements of these people are controlled and steered by biopolitical apparatuses (Foucault 2008), managing the circulation of bodies through strategies of governance that are always political and power-laden. Yet, as power at the airport is mediated, this also means that it is possible to challenge these spatial orderings, however minutely. My interviewee was also aware of the fact that his request for asylum would effectively move him into the category of asylum seeker. However, in the hour he had spent working up to this moment, his presence was innocuous and undisturbed, and he was able to "pass" as one among many travellers. Although he was removed from the premises once he requested asylum, this turn of events also highlights to what extent seemingly homogenous national and cultural spaces are not "natural" but rather the result of selective processes that actively produce the notion of difference. As Salter notes, "passage through airports condition and normalize particular identities, certain authorities, and normalize ways of managing the mobility of a population" (2008, XII). As such, the existence of the detention center in close proximity to the international airport becomes a condition upon which the smooth functioning of the airport is predicated, even if the existence of the detention center is invisibilized.

The detention center is, in other words, part of Schiphol's well-oiled machine; the openness of the airport is predicated on the detention center functioning like a prison camp in which the movement of the contained subjects is monitored and controlled. The creation of camps is not only a way of ordering and containing an undesirable population, but, importantly, also a means of separating them from the "authentic" subjects (van Houtum 2010, 97I). Detention centers are routinely 
placed in remote and rural areas ${ }^{16}$, reminiscent of the "out of sight, out of mind" principle: they are not really here if we do not see them or interact with them, or if we do not inhabit the same spaces. Interestingly, the Schiphol Application Center is located in the close vicinity of Schiphol Airport, and both are situated in the most densely populated area in the Netherlands, the metropolitan Randstad area. Here, detainment and "free" movement happen side by side, albeit in two distinctly separate spaces. Although the physical proximity between the two spaces is small, the space of the airport occupies a central position in the national imaginary (I will elaborate on this below), while the detainment center is symbolically peripheral, and this distinction is upheld and enforced by the state. This is evinced, for instance, by the response to the fire at the Schiphol detention center in October 2005 that claimed the life of eleven detainees. Although subsequent investigations ruled that the death toll was due to negligence of the guards on duty and the poor construction of the facilities, then-Minister for Integration and Immigration Rita Verdonk found that the staff had behaved "appropriately." Although the events sparked national outrage, the only party who was prosecuted was the inmate whose discarded cigarette was ruled to have started the fire. The state and government officials were not held responsible. Over the following years, a group of activists made efforts to commemorate the Schiphol fire and raise awareness of the events surrounding the deaths of the eleven detainees. In 2010 , however, the final official commemoration of the victims took place, which was attended by some forty people. The annual commemorations were discontinued due to the public's lack of engagement and waning interest. In her chapter in this volume, Liliana Ellena discusses dominant memory practices in Europe and notes that those whose deaths have occurred on the periphery of Europe constitute "ungrievable lives," to reference

16 My interviewee told me that after his seven-day detainment at Schiphol he was transported to an asylum center in the north-east of the country. He describes it as being "in the middle of nowhere" but nevertheless "the biggest one in the Netherlands," which is illustrative of the tendency to place large migrant populations in the least densely populated areas in the Netherlands. 
Judith Butler. My claim here is that the lives lost in the Schiphol fire are also peripheral in the sense that they do not occupy any significant component in the dominant national imaginary.

Mark Salter writes that: "Public and private authorities have taken advantage of the liminal character of airports to conduct policing and border functions, which take place inside the state but at the margins of the law. At the same time, more and more airports have accelerated lanes for the elite, transnational class and invisible corridors for the 'deportation class." (2008, xI) Schiphol Airport and its detention center also operate according to this duality. My interviewee describes the process immediately following his request for asylum as follows:

It took like half an hour for the IND guys to come. They came. They took us. We walked like ten to fifteen minutes and then they took us to another building. No, first we did the fingerprints, and then they took us to another building which is in Schiphol but like a five-minutes drive. Which is the prison. I don't know if you've heard about this prison: There are drug dealers, there are criminals, there are asylum seekers who've been there a week if they're Syrians or Palestinians, or a few months if they're another [nationality]. Yes, it was like five days. At 9 p.m. they'd close all of us in a room. Then at seven in the morning they'd wake us up and then we got the one meal for the day, which is like breakfast and lunch. And then you can go out for an hour to play football or something. Yes, it's a prison. It's like a good prison, but it's a prison.

Here, the proximity of the detainment center to Schiphol Airport is emphasized ("a five-minute drive") together with the distance between the bodies inhabiting the two spaces. Whereas the movement of people in the airport is relatively free (albeit organized), the movement of the people in detention is highly controlled and monitored. Moreover, the lumping together of different categories of unwanted others (drug dealers, criminals, asylum seekers) establishes a relationship of resemblance 
based on their physical location, as Ahmed has pointed out, and I find this also links to Balibar's conceptualization of borders as functional rather than ontological (Balibar 2002). In that way, the asylum seeker-illegal-criminal emerges as a complex construct that has no place inside the nation. As Charlie Hailey points out in Camps, these places of detention only serve to amplify concerns around unrestricted movements by foreign bodies. Such spaces can have an "open" or "closed" policy (the former refers to places that host people with very limited administrative and social rights, while the latter forcibly detain persons in one place). However, as Hailey states: "Less the resurgence of an authoritative political power, the camps are symptoms of a state's weakness and a resulting need to demonstrate the semblance of a policy of control" $(2009,244)$. What this means is that anxieties around uncontrolled migration prompt the building of special zones of confinement, which, when erected, prompt a fresh new wave of fear as they become the concrete embodiment of foreign bodies crossing European territories, perpetuating a vicious cycle. Meanwhile, the camps themselves become semi-permanent places of impermanence that some bodies can enter and leave freely (people like aid workers, camera crews, researchers, and reporters), while others cannot (the detainees themselves). Van Houtum (2010, 958) therefore speaks of

a constant border-work trying to separate the wanted from the unwanted, the barbarians from the civilized, and the global rich from the global poor in the territorial society. In so doing the EU increasingly is not only defining itself via its internal affairs, its ordering practices, but also by the production of new border rules and legislation towards its incoming migrants.

In other words, amplified anxieties around a "new" Other bring into being new ideas about a European culture that needs protection, which promotes the fortification of borders on all levels: social, cultural, political, institutional, territorial. While this bordering apparatus works 
according to particular structural orderings in each European nation state, they all promote the idea of a specific European space/identity union, as these bordering practices are specifically aimed at detaining and controlling people from outside of Europe. As Paasi notes: "The emergence of right-wing movements in European Union countries and in many of those that are negotiating to get into the EU - shows that the links between (a bounded) space, culture and politics are still full of political dynamite. It also shows how various spatial scales come together in the changing geographies of inclusion and exclusion." (200I, 23) Although Paasi's observations date back to $200 \mathrm{I}$, they still astutely describe the political climate in many European countries after 2015 . Detainment centers across Europe therefore contribute to "long-nurtured" European "civic drive to identify the foreign, to uphold the possibility of keeping the foreign foreign, of permanently foreignizing the '(racially) non-European'” (Goldberg 2006, 354), an imperial gesture that is still being implemented in order to control the imagined migratory masses' movement into both imagined and actual European spaces.

THE AIRPORT: NON-PLACE OR HERITAGE SITE?

Airports may be popularly considered as sites of "empty" signification because of the (visual, auditory, spatial) excess that characterizes them. This way, the airport is a "supermodern" site (Augé 2008), essentially devoid of meaning because it is too full of meaning; it represents too much, all at once (Lisle 2003, 6). However, this reading of the airport overlooks the ways in which these sites are imbued with cultural and national symbols that communicate specific meanings. Of course, national symbols at airports have a touristic and commercial value, and are typically found as items in souvenir shops, but they also "spill out of the souvenir shops" (Lisle 2003, I3). As I move through the different areas of Schiphol Airport, I am struck by the promotion of "typically" Dutch imagery that depicts commercialized aspects of Dutch culture: tulips, windmills, flat agricultural planes, and waterscapes. Typical and commercialized though they may be, Lisle describes these and other symbols as national heritage "at work" because of the "official' narratives 
of nation they encourage" (ibid.). It must also not be forgotten that airports are the first and last impressions of a place (Iyer I995, 54), and for national subjects, airports are the last and first impressions of "home" when they travel abroad. At Schiphol, there are now large screens installed at several locations, in- and outside the airport, showing videos with a goodbye or welcome-home message for a traveling loved one. These visuals amplify both the idea of "home" as well as that of the "homeland", and together with other symbols create the idea of Schiphol not only as a zone of transit but as a cultural space too. Sharon Macdonald (2013, I66) argues that ideas of national heritage in Europe have typically been disseminated through public institutions such as museums and monuments. A significant aspect of such objects and places is that they are "gathering grounds" for people to meet and experience "the nation" together. A current example of this is the Schiphol library. Opened in 2oro, the first of its kind, the library houses books, movies, music, and small exhibitions by Dutch artists. These materials are offered to travellers on intercontinental flights so that they can learn more about Dutch history and culture, but they also serve to promote a particular politics of belonging, one connected to the Dutch past and its cultural canon. In this way, the airport also becomes a site of national heritage. This is also evinced by the fact that Schiphol occupies an important position in Madurodam, a popular park that showcases miniature replicas of Dutch heritage sites and landmarks of cultural significance. Schiphol has been featured in the park since 1952. This information can be found at the Schiphol website as well, which has a comprehensive overview of Schiphol's Ioo-year "rich history." A notable portion of this overview is dedicated to the occupation and destruction of Schiphol by German forces during WWII. The subsequent reclaiming and rebuilding of Schiphol is framed as Schiphol's phoenix-like rise from the ashes of destruction. Once again, the memory of WWII is centralized as a defining moment. All of this points to the fact that Schiphol is not merely a transit zone (non-place), but a space with specific cultural roots tied to Dutch soil. Both its inception as well as its development to the international hub that it is now have always 
received great national attention and been well documented.

This way, the airport might be considered as one of the zones where cultural heritage and the cultural archive are made, negotiated, enforced, and contested. Wekker understands the cultural archive not as a single place or phenomenon where documents are stored, but rather as an accumulation of thoughts, feelings, and affects that shape the - in this case Dutch - cultural consciousness and canon. Importantly, Wekker notes that the cultural archive is built on a select body of memory that is frequently informed by the ways in which dominant understandings of Dutch colonial history are configured. Wekker states that the archive is to be found "in the heads and hearts of people in the metropole, but its content is also silently cemented in policies, in organizational rules, in popular and sexual cultures, and in commonsense everyday knowledge, and all of this is based on four hundred years of imperial rule" (2016, I9). My claim is that the airport does not stand outside of this logic; indeed, national and cultural markers are amplified here, making it a highly complex site where the cultural archive is played out.

\section{Conclusion}

In this chapter, I have sought to answer the question of how notions of European national and cultural heritage and belonging are controlled, secured, and contested through the controlled movement, detainment, and separation of foreign bodies at airports. To do so, I have situated my analysis at Schiphol Airport in Amsterdam, basing it on the detainment experience as recounted by one of my interviewees. Taking a phenomenological approach propounding that the organization of spaces is made up by the bodies inhabiting them, I have sought to establish the link between space, materiality, and belonging, while not advocating for unitary conceptions of any of these concepts. Following this, I have drawn on the work of Fatima E1-Tayeb, Gloria Wekker, and Theo Goldberg to point out how European spaces have been imagined as white/colorblind and are thus built on exclusionary practices. These practices largely 
take shape through the bordering processes that invoke the image of the "oppositional Other" who, in recent years, has been imagined as the (Muslim) migrant/refugee/asylum seeker. Following this, I have taken a closer look at how airports work as complex sites where power and belonging are constantly mediated.

Contrary to much of the literature on this topic, in this chapter airports do not feature as non-sites, but rather as places where notions of nationhood and cultural belonging are constantly enforced (and contested). The proximity between Schiphol Airport and the Schiphol detention center forwards this enforced logic. Detaining difference in the name of cultural and national homogeneity then becomes a question of spatial ordering. The national subject or the undesirable Other are both very much shaped by the spaces they (are allowed to) inhabit, and this logic of inclusion/exclusion has the same imperial/racial roots that shape many European spaces; i.e. it is part of a European cultural heritage. However, this is not to claim or invoke Europe as a homogenous space where notions of heritage and the cultural archive are not and cannot be contested - rather the opposite. I agree with Sharon Macdonald when she emphasizes the need to recognize and acknowledge "cultural alternatives" since they "can not only unsettle assumptions but can also open up new possibilities by highlighting other routes — other ways of doing memory, heritage and identity - that we might choose to take" $(2015,3)$. In this regard, it is important to keep in mind just how contested and multi-faceted the notions of Europe and airports can be, both as concepts and as physical structures (airports, for instance, have been theorized to be either sites of no signification or with an abundance of signification). Finally, the chapter highlighted some of the dissonances and restrictions that shape the ordering of Schiphol as a site of heritage dissonance: the close proximity of the airport as an open space and the detention center as a controlled space; the politics of belonging that is encouraged or discouraged in these places; and the peripheral or dominant memory practices that characterize both spaces. 


\section{Works Cited}

- Ahmed, S. 2006. Queer Phenomenology. Orientations, Objects, Others. Durham and London: Duke University Press.

- Ahmed, S. 2007. A Phenomenology of Whiteness. Feminist Theory 8(2): I 49- I68.

- Antonsich, M. 2010. Searching for belonging - An analytical framework. Geography Compass 4(6): 644-659.

- Ammeraal, S., F. Borekhof, and A. van Kampen. 201 4. Asylum Information Database National Country Report. The Netherlands. AIDA Project. http://www.asylumineurope.org/sites/default/files/report-download/aida_-_ netherlands_second_update_final_uploaded.pdf.

- Anderson, B. 2006. Imagined Communities. Reflections on the Origin and Spread of Nationalism. London and New York: Verso.

- Augé, M. 2008. Non-Places: An introduction to Supermodernity. London: Verso.

- Balibar, É. 2002. What is a Border? In Politics and the Other Scene. London: Verso.

- Balibar, É. Europe at the Limits. Interventions I8(2): I65-I7I.

- Easthope, A. I 999. Englishness and National Culture. London and New York: Routledge.

- Foucault, M., and M. Senellart. 2008. The birth of biopolitics: lectures at the Collège de France, 1978-79. Basingstoke [England]: Palgrave Macmillan.

- Goldberg, D. T. 2006. Racial Europeanziation. Ethnic and Racial Studies 29(2): $33 \mathrm{I}-364$.

- Hailey, C. 2009. Camps. A Guide to 2 Ist Century Space. Boston: MIT Press.

- Iyer, P. I 995. Where Worlds Collide. Harper's Magazine August issue: 50-7.

- Kisic, V. 2017. Governing Heritage Dissonance: Promises and Realities of Selected Cultural Policies. Amsterdam: European Cultural Foundation.

- Lisle, D. 2003. Site Specific: Medi(t)ations at the Airport. In C.Weber and F. Debrix (eds), Rituals of Mediation. Minneapolis: University of Minnesota Press.

- Macdonald, S. 20I3. Memorylands: Heritage and Identity in Europe Today. London: Routledge.

- Paasi, A. 200r. Europe as a Social Process and Discourse. Considerations of Place, Boundaries and Identity. European Journal of Urban and Regional Studies, vol. 8, no I: 7-28.

- Ponzanesi, S., and Blagaard B., B. 2or r. In the Name of Europe. Social Identities $\mathrm{I} 7(\mathrm{I}): \mathrm{I}-\mathrm{I} 0$.

- Salter, M.B. 2006. The Global Visa Regime and the Political Technologies of the International Self: Borders, Bodies, Biopolitics. Alterantives 3 I: I67- I 89 .

- Salter, M. B. 2008. Politics at the Airport. Minneapolis, London: University of Minnesota Press.

- Schiphol Amsterdam. Airport. Schiphol, 20 17, www.schiphol.nl/en/schipholgroup/page/amsterdam-airport-schiphol/. Accessed 7 April 2017. 
- Van Houtum, H. 20ro. Human Blacklisting: The Global Apartheid of the EU's External Border Regime. Environment and Planning D: Society and Space. Volume 28: 957-976.

- Wekker, G. 20I6. Introduction. White Innocence: Paradoxes of Colonialism and Race. Durham and London: Duke University Press.

- Whitley, L. 20I 5. More Than a Line: Borders as Embodied Sites. PhD Dissertation. Goldsmiths College, University of London. 



\section{ARTICLE 2 \\ Between"Fleeing"and "Taking Flight": Negotiating the Refugee Label}

To be published as part of the edited volume The Mobility of

Memory across European Borders: Migrations and Diasporas in

Europe and Beyond (eds. Passerini, Trakilović \& Proglio).

Berghahn Books, New York, forthcoming October 2020

\section{Introduction}

Whereas in recent years there has been a widespread tendency to represent migration to Europe as a relatively novel and exceptional phenomenon, mass movements and relocations have occurred throughout human history. However, as Nicola Magnusson argues, the use of categories such as (economic) migrant, refugee, asylum seeker, and illegal immigrant to classify and label different mobilities and mobile subjects is indeed a prominent characteristic of our times. Magnusson (20I I, I5) further points out that these labels are not arbitrary; they are linked concretely to systems of control that direct the social and spatial movements of migrating subjects. Therefore, the categories of migrant and refugee carry particular meanings that may impact strongly on societal perceptions as well as on individuals' self-perceptions. These themes featured significantly in the interviews that I conducted with individuals in the Netherlands, focusing on their migratory trajectories to and through Europe in the context of the Bodies Across Borders in Europe: Oral and Visual Memory in Europe and Beyond (hereafter BABE) project. Respondents expressed their feelings of being overwhelmingly constrained by the labels "migrant," "refugee," "asylum seeker" and others, and they frequently articulated their desire to "lose" these markers so that their "true" identities (e.g., an artist or student) would become apparent. All of the respondents were particularly uncomfortable being 
perceived as migrants or refugees and professed a desire to shed or overcome this label, deploying various discursive and representational tactics to accomplish this.

Rather than opting to conduct an inventory of the varying responses to the "refugee label" (Zetter I99I, 2007) that entailed a "studying down" perspective, my aim was to "study up" (Nader 1972; Gusterson I997; Coleman 2012) and also to present the commentaries of my respondents on how they personally negotiated the migrant/refugee label as points of elaboration on the modes of discourse and governance that produce these very same labels. To accomplish these objectives, I studied several critical conceptualizations of the figure of the refugee/migrant that emphasize both the reductive character of this category as well as the possibilities of its modification at an individual level, reading my respondents' views in dialogue with these theoretical framings. In doing so, I critically examined the possibility of - and potential problems associated with - "recovering" the notion of the refugee/migrant from its current marginal position and according it a more central position within the discourse. Accordingly, I examined Dutch responses to the recent migration crisis that have been widely manifested in polarized and sensationalist public opinion. One of the aims of this paper is to instill a more nuanced understanding of the migrant/refugee label into this discussion. The need for this nuanced understanding has become particularly urgent in light of the fact that borders in contemporary times have undergone a shift from the

physical (the gate to European territories and citizenship) and [the] symbolic (the myth of Europe and its idea of superiority) to material borders (the marked body of foreigners, immigrants and asylums seekers) which become 'border' figurations (through constructions of otherness, foreignness, and alienness)" (Ponzanesi and Blaagaard 201 I, 3).

In the above quote, Ponzanesi and Blagaard are referring to the phenomenon of an "embodied border" in which certain groups of people 
come to stand for larger societal forces. Accordingly, the migrant becomes migration. At times, migration even becomes a natural force, thereby losing all of its societal, historical, and political connotations. Conceived in this way, it may be framed as a natural disaster, as seen, for example, in references to "waves" or "streams" of migrants, or of migrants "flooding" European shores. Such framings indicate that the discourses surrounding migration not only render people as other but also dehumanize them.77 Both "migrant" and "refugee" could be relatively loaded terms during my interviews, which centered on migratory trajectories and implicitly or explicitly addressed the interview subjects as migrants and/or refugees. There are, I believe, two factors that can help explain the apprehension towards these terms. First of all, the act of addressing someone is can be understood as an interpellative ${ }^{\mathrm{I} 8}$ gesture that produces, in a sense, the addressee. Secondly, as Ramaswami Harindranath $(2008,3)$ points out, the "politics of naming the Other," conceived here as the refugee, migrant and/or asylum seeker, is predicated on "residual aspects of the colonial era" that "continue to colour perceptions of the non-Western world through the politics of naming, thus establishing the ideological difference from the West." Together, these two factors work according to a mechanism of interpellative Othering that results in further alienation, rather than subjectification, as migrants and refugees are already made to inhabit a liminal role in culture and society and

17 Geert Wilders, the Dutch far right politician, used the term "asylum tsunami" to connote the need to "waterproof" Dutch borders.

I 8 Louis Althusser argued that subjects come into being through a process of "interpellation" or "hailing," that is, speech acts directed at a person and which, through their pronouncement, serve to define the person to whom they are directed. The addressee recognizes that he or she is being addressed and thereby enters into a state of subjectivity, implicitly recognizing that the interpellation in question is being directed at him or her. Althusser argued that identification through interpellation is indicative of the working of ideology: "Ideology 'acts' or 'functions' in such a way that it 'recruits' subjects among the individuals (it recruits them all), or 'transforms' the individuals into subjects (it transforms them all) by that very operation I have called interpellation or hailing, and which can be imagined along the lines of the most commonplace everyday police (or other) hailing: 'Hey, you there!' (Althusser I97 I, I62-63). 
not infrequently experience a "linguistic and cultural void" (Longinović $2018,892)$ in the spaces they come to inhabit. In this chapter, I consider how my respondents navigated the restrictions they experienced as a result of being labelled (as migrants and/or refugees) and examine to what extent the strategies they employed reproduced or contested existing discourses.

\section{Analytical and Methodological Framework}

The central preoccupation of this paper is to understand how the notion of the refugee/migrant operates at individual (personal), symbolic, and structural levels and according to which (dominant) discourses. I take my respondents' views on their own experiences with labelling as my analytical starting point, subsequently expanding the focus of the analysis to include a reflection on the migration discourse that produces the refugee/migrant, through the use of an "up, down and sideways" (Nader I972) approach whereby individuals' responses to the migrant/refugee label are studied in tandem with and as a response to the discursive and institutional frameworks that produce and uphold these categories.

In the course of my fieldwork undertaken for the BABE project, I carried out semi-structured interviews with 30 individuals with a migration background $^{\text {19 }}$ covering fourteen countries of origin. Most of

I9 In the Dutch context, 'person with a migration background' carries a loaded meaning, since it is also the term that is since 2016 officially in use by the Central Bureau for Statistics (CBS), replacing the previously criticized and polemical term 'allochtoon' (allochtone) to denote a person of whom at least one parent was not born in the Netherlands. The new terminology appears more descriptive but ultimately performs the same ideological function as its precursor, namely to distinguish between 'native' and 'non-native' Dutch as way to establish degrees of national belonging. Thus, I am aware that 'person with a migration background' is an ideologically inflected term; my use of the it here is part of my aim to problematize the meaning of such labels. In the context of my research, the term had a more specific meaning as well, as all of the individuals I interviewed (save one) had themselves migrated to the Netherlands at some point in the last 20 to 25 years and thus were 'first generation migrants.' 
these interviews were conducted with individuals, but several were also conducted in group settings, and they typically lasted from 40 minutes to one hour. During these interviews, the emphasis was on how the respondents perceived their journey to the Netherlands, focusing on and how they described, remembered, and visualized this trajectory. Aside from differences of gender, age, and educational level, and the amount of time they had spent in the Netherlands up to the time of the interviews, the respondents differed markedly in terms of their backgrounds. ${ }^{20}$

Respondents' accounts of their journeys to and through Europe also tended to differ greatly, varying from a few days to several months. Although this group of respondents was highly heterogeneous in many ways, almost all of them expressed their dissatisfaction at being perceived exclusively as migrants or refugees. Many professed a desire to somehow escape or at least transform this category, which in their experience was confining. These responses not only reveal something about individuals' self-perception but they also form a critique of the discursive and institutional mechanisms that produce these categories. My aim is to understand these individual responses within a wider political discourse on migrants and refugees, while attending to how individuals negotiate their relationships to these labels. Nevertheless, my selection and highlighting of the views of the small number of respondents in this chapter does not imply that these views merely echo sentiments shared with other respondents in the study, who are not featured here. Nor should they be considered representative of those of other individuals, not included in this study, who are labelled as migrants/refugees. These accounts should be understood as individual accounts that nevertheless communicate something about the larger political moment currently unfolding in Europe that is characterized by a charged and not infrequently hostile social and bureaucratic climate with regard to migration. The individuals whose accounts are presented here all expressed

20 Interviews were also influenced by the different backgrounds of the respondents. For example, when interviewing a visual artist, I focused on the respondent's migration trajectory as well as on his or her artistic outputs. 
how they have been personally impacted by the constraints placed upon them through the ascription of a migrant/refugee label. Accordingly, it was possible to contextualize the ways in which dominant discourses surrounding migration take shape.

While these individual responses cannot simply be viewed as disruptions or displacements of the larger structural frameworks in which they operate, there should be room in the analysis for agential possibilities of individuals to resist, subvert, or negotiate the migrant/refugee label in their own lives. A nuanced approach that can account for both personal, embodied experiences as well as the confining structures that contain them, without collapsing one into the other is therefore required. Alice Szczepaniková points to the dualism inherent in refugee studies, which tend to emphasize structures of control on the one hand, and strategies of resistance on the other hand $(2008,35)$. In other words, within the literature on refugees, there is a tendency to produce a separation between studies focusing on the concept of the refugee (deployed in policies and debates, and within institutional frameworks) as a mechanism of control, and studies highlighting the refugee experience. The latter works emphasize the agency of the research subjects in question, but do not necessarily complexify this agency by embedding it within a broader structural framework (2008: 35). Szczepaniková addresses these issues as follows:

What seems to be missing is a perspective or a framework which would allow us to see displaced people as embodied and diverse actors who continuously strive to adopt the rules of the game to their own goals, yet are always already constrained by these rules. That is, to see them not only as objects of political violence back home and restrictive policies in their destinations but to take account of their strategic actions and decisions in the sense that they continuously challenge and transform the content of the refugee category. $(2008,36-37)$

Thus, Szczepaniková advocates for research that can accomplish both actions, that is, provide an account of the ways in which the label of the refugee is produced as a normative category operative in policies and politics, while also allowing for experiential accounts of 
the label bearers who challenge this category in their day-to-day lives. She therefore introduces a "strategic-relational approach" to 'a refugee.' Accordingly, from the start, the domains of "structure" and "agency" are conceptualized not as separate entities but as categories that operate together and co-constitute each other $(2008,38)$. I find this approach productive and have attempted to use it in this chapter to produce an account of the dominant discourses and institutional constraints that characterize the migrant/refugee experience, as well as the ways in which these constraints are mediated and negotiated by those subjects who live these realities.

The Netherlands was selected as the site of analysis for practical reasons because all of my fieldwork, and hence all of the interviews I have conducted in the context of the BABE project, took place there. Many respondents, notably those featured in this chapter, referred specifically to the Dutch cultural and political context when speaking about integration procedures and their experiences of social inclusion and exclusion. Yet, the Dutch response to migration in the twenty-first century, and especially following the 2015 "migration crisis," which has entailed increased securitization, fortification of borders, and the rise of xenophobic political sentiments, is part of wider European and even global tendencies. Accordingly, the paper's analytical focus extends beyond the national, without losing sight of the specificities of the Dutch situation. In the following section, I examine how the migrant/refugee category is rejected, questioned, and reappropriated, as reflected in some of my respondents' views, and how these experiences reflect larger societal and institutional constraints and existing ideologies of citizenship, nationhood, and belonging.

\section{Negotiating Belonging through the Refugee Label}

In the interviews I conducted in the context of my fieldwork for the $\mathrm{BABE}$ project, my respondents would largely express dissatisfaction with identity categories that marked a certain kind of distance (from 
an assumed "authentic" national subject) and that subsequently "stuck" to them. Some of these categories were "migrant," "foreigner," "refugee," and the specifically Dutch allochtoon, which is explicitly connected to land or soil. ${ }^{25}$ In The Cultural Politics of Emotion (2004), Sara Ahmed introduces the notion of the sticky sign, viewed as an interpellation that is intended to keep subjects in place by defining and drawing a border around their identity. These signs truly "stick" as they carry with them additional meanings that mark bodies and keep them from moving in other (possible) directions. Ahmed provides the example of the racist proclamation Paki, with its underlying meaning of immigrant and outsider. One of my respondents ${ }^{22}$ reflected on the impossibility of being "unmarked," especially when it comes to the "refugee" label:

I did not know that I would be labelled, although I'm open-minded if you know me, and I speak English, but I did not know that I would not be welcome, or [that] I'd be treated based on my race or such things. I'm not a religious guy, my family are Muslims-I'm not — but I am treated as such because I'm from Syria [sic]. -I'm labelled, I mean, as a refugee. I thought 'if you don't consider yourself a refugee, you

2 I The Dutch terms allochtoon and autochtoon describe a difference in origin or descent, serving to keep a considerable part of the Dutch population symbolically outside of the nation (Jones 20I 4: 26). An individual is considered allochtoon if he or she, or even if one or both of this individual's parents, was born outside of the Netherlands. By contrast, an autochtoon is a person who was born on Dutch soil. In popular and political Dutch discourses, allochtoon has become synonymous with non-Dutchness, regardless of birth status, meaning that both terms operate in a social/cultural dimension. Paul Mepschen writes that "ethnicized and racialized groups are now construed and defined as cultural Others and as such are asked to integrate into the fiction we call Dutch "culture"' (Mepschen 2016, 23). This means that the term allochtoon can "stick" to somebody who falls outside of its definition if this individual is racially and/or ethnically marked as "Other."

22 A 29-year-old man from Syria whom I interviewed in Amsterdam in January 20I7. At the time of the interview, he had spent approximately one year in the Netherlands. 
would live as an expat.' But I figured out it's not like [that]. Even people who are being good to you - they're good to you because you're a refugee. So, you will be labelled anyway, even if you never have any bad experience with racism or discrimination - you will be labelled as a refugee. So that was ... unexpected.

Here, the respondent uses the word 'label' himself (instead of using "word" or "term," for instance), thereby invoking the ideological dimension of this conceptual category, which is deployed as a mechanism of control. Scholars have engaged with the problem of signification that inheres in the term "refugee." Notable among such works is Roger Zetter's I99I analysis on the practice of "labelling" refugees in bureaucratic and humanitarian aid contexts that sought to reveal how these mechanisms frequently produce narrow, constraining definitions of refugees according to the interests and internal workings of the concerned organizations (Zetter 2007, I93).

In the contemporary era, which is characterized by intricate migratory trajectories associated with a "process of bureaucratic fractioning," (Zetter 2007, I74) the complexity of this practice has increased. Bureaucratic fractioning entails the invention of ever proliferating labels in a (failed) attempt to accommodate a multiplicity of new situations of persecution and statelessness. It contrasts starkly with the relatively homogenous processes of migration, largely within the Global South, during the r970s and I980s. According to Zetter, faced with mass migration, national governments in the Global North (notably Europe at present) are transforming the refugee label; a process that was previously "monopolized" by NGOs. Moreover, this label (and those connected to it) has become politicized and has been consequently deployed actively in populist, anti-migration, national agendas, becoming part of a wider political discourse (Zetter 2007, I74).

This process has been clearly apparent within Europe since the 2015 "migration crisis." Further on in this chapter, I will elaborate on the current political climate prevailing in the Netherlands, specifically 
in relation to the migration debate. Zetter (2007, I87) argues that the label of refugee, which was previously relatively homogeneous, has been transmuted in the current era into a plethora of other labels (e.g., illegal/economic/bogus asylum seeker), signifying marginality, a threat, and otherness. He points out that whereas previously, the refugee label was equated mainly with "rights and entitlements," in the current political situation, it operates within a discourse of "identity and belonging embedded in debates about citizenship and the 'other' in an era of global migration" (2007, 190). This holds true for the above testimony, in which the respondent reflected on the constraints placed upon his identity as a result of being "pushed" into the refugee category by prevailing social and political discourses in the Netherlands.

Zetter's analysis highlights the role of language/discourse as an apparatus of meaning as well as of control. He explains his choice of the word label in connection with refugees as follows:

As opposed to other terms, for example, 'category,' 'designation,' or 'case,' the word 'label' better nuances an understanding which: recognizes both a process of identification and a mark of identity; implies something independently applied, but also something which can be chosen and amended; has a tangible and real world meaning, but is also metaphorical and symbolic. (Zetter 2007, I73)

In other words, the term "label" is useful because it signifies the governmental and bureaucratic structures that impose it on (or deny it to) individuals, while also signifying an agential dimension through a process of individual appropriation or rejection. My approach to the migrant/refugee discussion is very similar. Recognizing that labelling is frequently a top-down action that imposes or withholds certain (institutional) categories on individuals, I nevertheless want to acknowledge and leave space for exploring the ways in which these categories are managed, contested, and possibly reworked by individuals according to a bottom-up logic. The respondent, cited above, described the refugee 
label as a social and discursive constraint, impacting on his self-perception and on how others perceived him. However, as I show later, other respondents appropriated and reworked this label, according to their personal situations, into a less constraining category.

Furthermore, this testimony reveals that the "reading" of an individual as a refugee is directly linked to their place of origin (Syria in this case), even though the respondent perceived himself as an "expat," implying a choice over his mobility rather than the compulsion to flee. The term refugee, in particular, conveys a strong connotation of helplessness, prompting host societies to offer their services to this disadvantaged group and creating the perception of a burden. In this respondent's view, being an "expat" gives him considerably more agential status because the presumed relationship between the "native" subject and the expat can be one of exchange, whereas the refugee is relegated to a position of passivity and dependence; a position that is expected to result in an attitude of gratitude toward the host country (Ghorashi 20I4, I I I). For the respondent in question, "expat," is a term and a condition that he has chosen intentionally, whereas "refugee" is a label that was imposed on him. However, "expat" refers to a "different category of foreigner"(Smith 2014) and is frequently applied to someone from the West. Because this individual is from Syria, he is perceived by others as a migrant or a refugee. Consequently, while he could easily claim to be an expat at a personal level, this is not possible at a social/structural level. The expectations he had of the circumstances that would await him in the Netherlands did not coincide with the reality of the situation, which is also apparent in the diagram that he drew (See Figure I), depicting his life trajectory, including his migration experience. In this diagram, the red line represents his life trajectory up to the time of the interview, the black line represents the reality of his overall life satisfaction, and the green line represents his expectations for his unfolding life. It is evident from the diagram that his expectations and the reality he experienced differ markedly. Of note are his expectations, envisioned as a steadily rising line throughout the course of his life, whereas the reality is in striking contrast. There is considerable divergence in his expectations 
and the reality he encountered after his arrival in the Netherlands. The process of categorization, entailing the assignment of the refugee label and the social constraints accompanying it seem to have directly impacted on this situation.

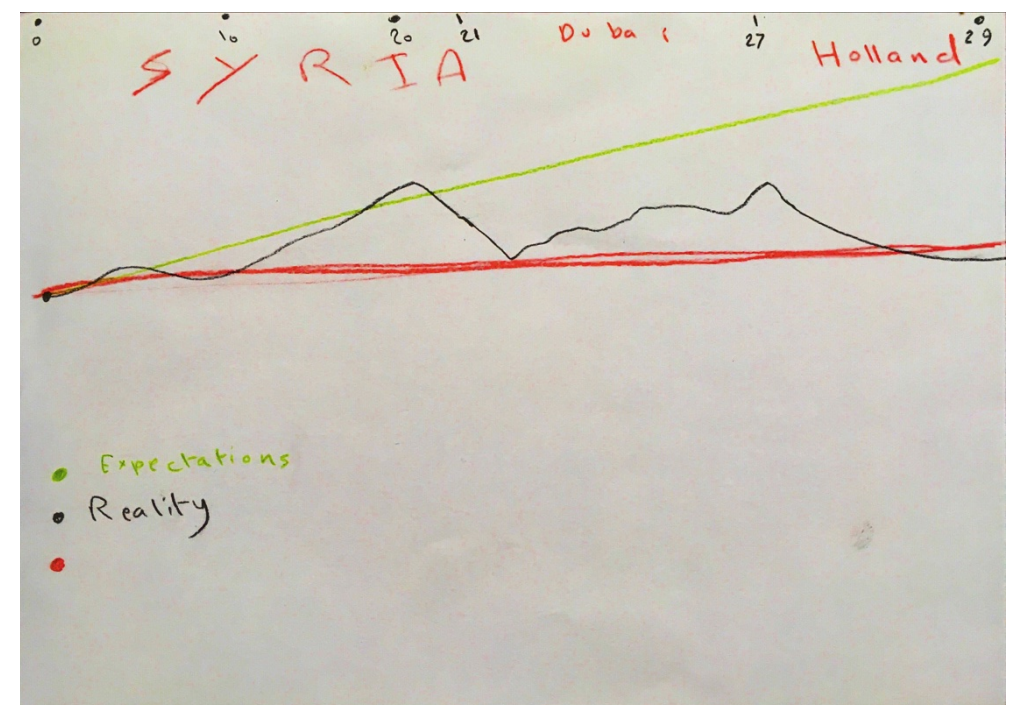

FIGURE I. The respondent's drawing of his migration trajectory (interview January 2017)

Another respondent ${ }^{23}$ spoke of the distancing gesture and categorical thinking entailed in the term refugee in relation to his own experiences:

[When I] first I came here, I didn't realize that when I started to talk with people and meet people ... [that they] have ideas about refugees [as if they] are other creatures coming from other lands, maybe from Mars, and they [think they] don't

23 A 22-year-old man from Syria whom I interviewed in Utrecht on I7 December 2015 . 
know anything about us, and we don't know anything about them. But actually we know about them — we know almost like everything, and it's just normal. I had this conversation with a Dutch friend, and we're talking about refugees and how people look at refugees, and one of my friends, she told me, 'When I'm talking with my friends about [how] I have you and other Syrian friends, they say, 'What's it like to have a refugee as a friend?' So, she invited us to her house to cook and make dinner there, and she invited her friends also. And we went there, and after we finished talking, they told her, 'Yeah, they are almost like us.'

The expression "almost like us" is simultaneously placating and distancing, seemingly allowing entry into the realm of Dutchness and/or Europeanness, while serving as a reminder that this transition will never be complete. Thus, refugees are positioned outside of the imagined community ${ }^{24}$ of a nation state, even when they physically inhabit. The term "refugee" signifies a sudden arrival, whereas "authentic" national subjects are not burdened by this signification. Sara Ahmed observes that "we only notice the arrival of those who appear 'out of place.'Those who are 'in place' also must arrive; they must get 'here,' but their arrival is more easily forgotten, or not even noticed" (2004, 9- I0). Specifically, Ahmed talks about (national) belonging actualized through the inclusion and exclusion of racialized bodies. In the above testimony, the respondent describes the refugee as a cultural other, which reflects his experience of interacting with Dutch people.

As my fieldwork was conducted in the Netherlands, I am situating this analysis in the specificity of the Dutch context regarding the discourse on the cultural other, particularly in light of Europe's migration

24 In Imagined Communities, Benedict Anderson writes of the imagined or constructed nature of nations and national belonging. He posits that nations are imagined because most members of a nation will never meet the majority of their compatriots. Nevertheless, the imagery of joint belonging is instilled into every subject (Anderson I99I, 6). 
'crisis.' First, it is necessary to foreground an understanding of the way in which the language of Dutch racism has changed over time. As Philomena Essed points out, racism in the Netherlands became less overt during the second half of the twentieth century, which, of course, does not mean that it was absent. Following $9 /$ I I the language of racism in the Dutch context was most notably directed at the imagined threat embodied by the Muslim Other, which is reflective of a wider European tendency. However, Dutch racism is also very specific because there is no established discourse for addressing its "layered nature" (Essed and Hoving 20I4, Io). In the post-9/I I period, the voicing of negative opinions toward Muslim minorities and immigrants (often collapsed into one category) became more acceptable in the Netherlands. Moreover, with the prompting of a "new realism" discourse (a term coined by Boukje Prins) in the Netherlands, which legitimized explicitly xenophobic and racist stances against the cultural Other, the propagation of antiracist and multiculturalist values that the Netherlands had been renowned for in the past came to be perceived as not being in touch with reality (Essed 201 2, I5).

Critically reflecting on the backlash against the "ungrateful Other in the Netherlands," Halleh Ghorashi notes that "the new realist is someone with guts; someone who dares to call a spade a spade; someone who sets himself up as the mouthpiece of the common people and then puts up a vigorous fight against the so-called left-wing, "politically correct" views of cultural relativism" (2014, I08). Ghorashi (2014, I I I) further notes that in recent years, whereas there have been shifts in tone when talking about the Other (e.g., from framing migrants as positive influences on Dutch society to framing them as a threat), the overall attitude to migrants as not being compatible with Dutch society and Western values has remained unchanged. The respondent cited above shows awareness of the fact that the refugee falls outside of the category of nation, stating further on in the interview that "they [Dutch people] have the idea that refugee is a human [second class]." Taking into account the fact that this respondent described his experience of being labelled a refugee, specifically in the Dutch context, this situation 
may be understood as an instance of "categorical thinking" that Halleh Ghorashi describes as a particularly resonant contemporary phenomenon in the Netherlands when it comes to relating to Others in general and to migrants/refugees in particular. This phenomenon is largely rooted in the Dutch cultural history of "pillarization" that continues to be translated into the idea that certain populations within society inhabit different worlds from the assumed "native" subject, who remains largely unmarked (Ghorashi 20I4, II), The sentiment expressed in this respondent's testimony ("they are almost like us") attests to the notion that refugees are perceived as cultural others, and that their practices are incompatible with Dutch cultural practices, or at the very least that the latter are completely foreign and unknowable to them.

The new realism discourse makes it possible to use discriminatory language explicitly in the name of "honesty," while the pointing out of racism becomes forbidden (Ghorashi 20I4, II3). According to Gloria Wekker (2016, I), racism in the Netherlands is operative because of its deniability and the overwhelming disconnect that still exists with regard to the dominant Dutch self-conceptualization and the 400-yearold Dutch colonial history. Additionally, Wekker (2016,6) argues that in general, there is no identification with migrants (and, by extension, refugees) in the Netherlands, even though every sixth person in the country has migrant ancestry. The dominant conception of Dutchness is still equated with whiteness and Christianity, and anyone who carries outward signs of otherness (reflected in language, skin color and/ or cultural belonging) is encouraged to shed these markers (either symbolically or literally) through acceptance of "the assimilation model of monoethnicism and monoculturalism" (2016, 7). Therefore, the above respondent's assessment of the refugee being a "second class human being" falls within the discourse of the cultural other in the Netherlands which has always been racialized, even if this has not always been overt.

Responses like these enabled me to reflect on language constraints within the scope of my research and to explore the possibility of reconfiguring static identity markers according to a more deconstructive and subversive logic. Although it may be very difficult to intervene in 
the discourse on refugees at a structural level, respondents constantly applied strategies of rejection, appropriation, and even subversion of the refugee label at an individual level. For instance, the second respondent's wish to unmark himself as a "refugee" would appear not to entail a desire to become Dutch per se:

For me, personally, I don't want anyone anymore to treat me as refugee. That's why I tried as soon as possible to start with my studies and my university. If someone asks me, I don't have to say 'Yeah, I am refugee,' but I can say 'Yeah, I am student.' Student is really a better word than refugee, because when you say refugee, they say, 'Okay, I see, [I'm] sorry for you.'

The self-definition as a student rather than as a national subject appeared to circumvent notions of national belonging altogether by stepping outside of the bounds of (non-)Europeanness and claiming a space for alternative self-conceptions. A student, belonging to no nation in particular, is presumably a cosmopolitan subject whose movement is not restricted. However, the categories of refugee and student are also considered incompatible, implying that a refugee cannot be a student and vice versa. Whereas the refugee is bureaucratically, discursively, and socially positioned outside of the nation, the student is much more structurally embedded within society as a member. Therefore, although this respondent did not directly refer to national and cultural belonging, his rejection of the refugee label in favor of the student label should be understood as an attempt to achieve integration in terms of the Dutch model of citizenship. In the Dutch citizenship test, which is a popular European model, newcomers are urged to integrate within Dutch society by adopting markers of Dutchness that are configured according to liberal and secular values (de Leeuw and van Wichelen 2012). Against this background, the label "student" should be understood as a "safe" category in the sense that it does not convey overt markers of cultural and racial difference, or possibly of historical and imperial violence, unlike the label "refugee," which serves as a reminder of such difference and violence, therefore representing a threat to cultural and national autonomy. 
According to de Leeuw and van Wichelen (2012, 202), for migrant/ refugee/non-Western newcomers, the pressure and need to integrate into Dutch society is associated with "civilizational pathos" that results from "the erasure of violence in the past." This view echoes Wekker's argument that the suppression of colonial history and memory within the national consciousness contributes to and actively produces a racialized image of the Other. Based on a study of postcolonial migrants in the Netherlands, Ulbe Bosma concludes that a postcolonial discourse is absent and that integration policies are predominantly assimilationist, thereby foreclosing the possibility of cultural diversity in the country (Bosma 20I2, 2 IO). Associated with this civilizational logic are secular and liberal conceptions of the self, emphasizing self-realization, productivity, and individualism. The responsibility for turning the refugee label into a label such as that of student, which is more acceptable and useful, falls on the individuals themselves. This is apparent in the following testimony of a third respondent $\mathrm{t}^{25}$ :

I tried to get out of these clothes - the 'refugee clothes'-and I thought that after taking the permit I was no longer a refugee. I am not [an] asielzoeker [asylum seeker], I am [a] statushouder [in possession of a residence permit]. So, I thought that I was not a refugee anymore. But then I met a lawyer who told me that I am a statushouder with the status of refugee. So, I am a refugee, still. I cannot fight against being a refugee anymore. But, I always fight against using that name, 'refugee.' Because, the image of a refugee is that of a person who has nothing to provide; who doesn't know anything about the civilized nature of the country; who doesn't know about mobiles or laptops; who rides donkeys or camels and goes to work, which is farming. But, I have had a laptop since 2007 and I have used Internet since the day I got the laptop as a kid and a mobile a long time ago. I know the Internet, I had three emails and I had a Facebook account, which is amazing [laughs], and I had Twitter, I had LinkedIn, and I am educated. I speak several languages. So, it's not like I'm the empty person who is known as a refugee - that type

25 This interview was conducted in Amsterdam in January 2017. 
of image. And that's why the Prime Minister of Hungary [Orban] was angry with people who came in with the iPhone 6 because it doesn't fit with the image [of the refugee]. But the refugees are not people who came for commercial and economic reasons, they also came from a war, and Syria was really modern and civilized before the war; we had everything. I had fast internet in my house. That was the actual situation.

People approach me because I have a huge number of connections in Amsterdam now, and in the Netherlands in general, I am able to reach political people and normal people and many organizations in the Netherlands. I am creating my own business and my own organization, so with all of these things, people approach me as someone who is, let's say, the 'good newcomer.' And I am trying to change the name 'refugee' to 'newcomer' or 'global citizen.' People know that that I am a refugee but I am not a refugee [associated] with this type of image. And people know me as a person who is a good talker and who is convincing... People know that I am a matchmaker, a storyteller; they know me as an ambassador ... They know me as an entrepreneur, a student at the hotel school. They never describe me as a refugee. They can say 'Oh, he's from Syria,' but they never say 'He's a refugee from Syria' because that's so annoying. That's somehow insulting.

The third respondent describes his initially false and somewhat naïve assumption that as he would be able to fairly easily shed the refugee label. When this did not turn out to be the case, he opted for resignification of the label into something that he considered more positive. He opposes the popular conception of the refugee as a person who is completely destitute, helpless, and disconnected from the world - a "speechless emissary" (Malkki 1996). Against this image, he has fashioned an alternative understanding of the refugee as someone who is capable, connected, modern, educated, and entrepreneurial. However, this more positive notion also fits neatly into the secular and liberal model of the Dutch citizen that de Leeuw and van Wichelen critique. In describing his self-conception, the respondent emphasizes self-realization, self-presentation, personal and professional connections, and ultimately the ability to be a productive member of society, implicitly implying that these are not the 
characteristics of a refugee. His desire to change the refugee label into "newcomer or global citizen" is grounded in the idea of a cosmopolitanism that entails discursively erasing specificities of cultural and historical contexts and processes of political violence. Although this may appear as a circumvention of national categories and norms, cosmopolitanism is actually better understood as an ideal that supports a particular kind of Western-coded nationalism. (Derrida 1992) Moreover, cosmopolitanism as an ideology is operationalized through institutions like the European Union, promoting a shallow idea of national diversity that erases historical and cultural specificities. It also negates Europe's historical involvement in colonialism and imperialism and the reproduction of these structures in current neocolonial capitalist frameworks. Cosmopolitanism therefore exists due to the historical disavowal of old and new colonialisms (Bhambra 2015) Therefore, apart from contributing to a liberal, secular notion of personhood that is based on ideas of self-actualization, productivity, and participation in the (host) society, and to class identities, the cosmopolitanization of the refugee label implies a coerced loss of historicity and political context. While this strategy may be questionable at the structural and symbolic levels, at a personal level it appears to be a beneficial one for individuals, as it can improve their self-image and confer on them a sense of agency with regard to a social category that they experience as highly coercive and constraining. Cosmopolitanization of the refugee label, then, is one way for an individual labelled as a refugee/ migrant to diminish the associated experience of distancing at a personal level. This desire to universalize the "cosmopolitan refugee" label may be expressed more strongly by individuals who arrived in Europe/the Netherlands more recently, notably post-2015, when the migration phenomenon was constructed as a "crisis," as in the above three cases.

However, cosmopolitanization of the refugee label should not be understood solely as a reiteration of established identity norms; it can also serve as a possible ideological critique. One of my respondents ${ }^{26}$,

26 This interview was conducted in October 2015 in Den Haag with RussianDutch visual artist Olga Grigorjeva 
a visual artist, aims to convey a less static idea of the migrant/refuge in her work. For instance, one of her paintings (See Figure 2) features a transformation of the trope of "fleeing" refugees to one of refugees "taking flight," which suggests multiple modes of mobility. In this depiction, the refugees cease to be constrained by a static marker and take on the possibility of being multiply mobile on account of previously having been forcibly mobile. In this painting, figures are shown flying over a distinctly Dutch landscape (indicated by scattered windmills), suggesting that this mode of mobility allows for a dissolving of the structures of national territory occurring on the ground. The painting's allusion to a (European) space existing beyond the nation state suggests a possible nomadic mode (Braidotti 20I I) that enables the recovery of the figure of the marginalized refugee.

It is worth considering whether, and to what extent, the nomadic figuration of the refugee differs from the previously discussed cosmopolitan conceptualization. According to Genevieve Lloyd, Rosi Braidotti's notion of the nomadic subject is based on the notion of nomadism as an ontological reconceptualization of "the human" which is realized through an "enlarged cosmopolitan subjectivity" (Lloyd 2013, I88). The key point here is that the refugee/asylum seeker/migrant should not be thought of as a nomad, which might lead to yet another process of categorization. Instead, the challenge is to think "nomadically" through these conditions so as to possibly bring to light "assumptions implicit in prevailing ways of thinking, assumptions that can be shaken to make space for imagining alternative approaches to 'problems' which have otherwise proved intractable" (Lloyd 2013, I87). For Braidotti, the nomad represents a figuration; a conceptual entity that can shed light on existing conditions and could potentially offer alternatives to existing institutional and discursive constraints. The nomad represents a mobility that the traditional notion of the refugee lacks, given that it is usually 'fixed' in and by a particular definition, resulting in the overdetermination of its meaning. Conceptualizing the refugee "nomadically"implies the ability to dislodge this term from these static contexts. This does not mean that the nomad stands for "nothing; rather, as Braidotti (201 I, 39) herself points out: 


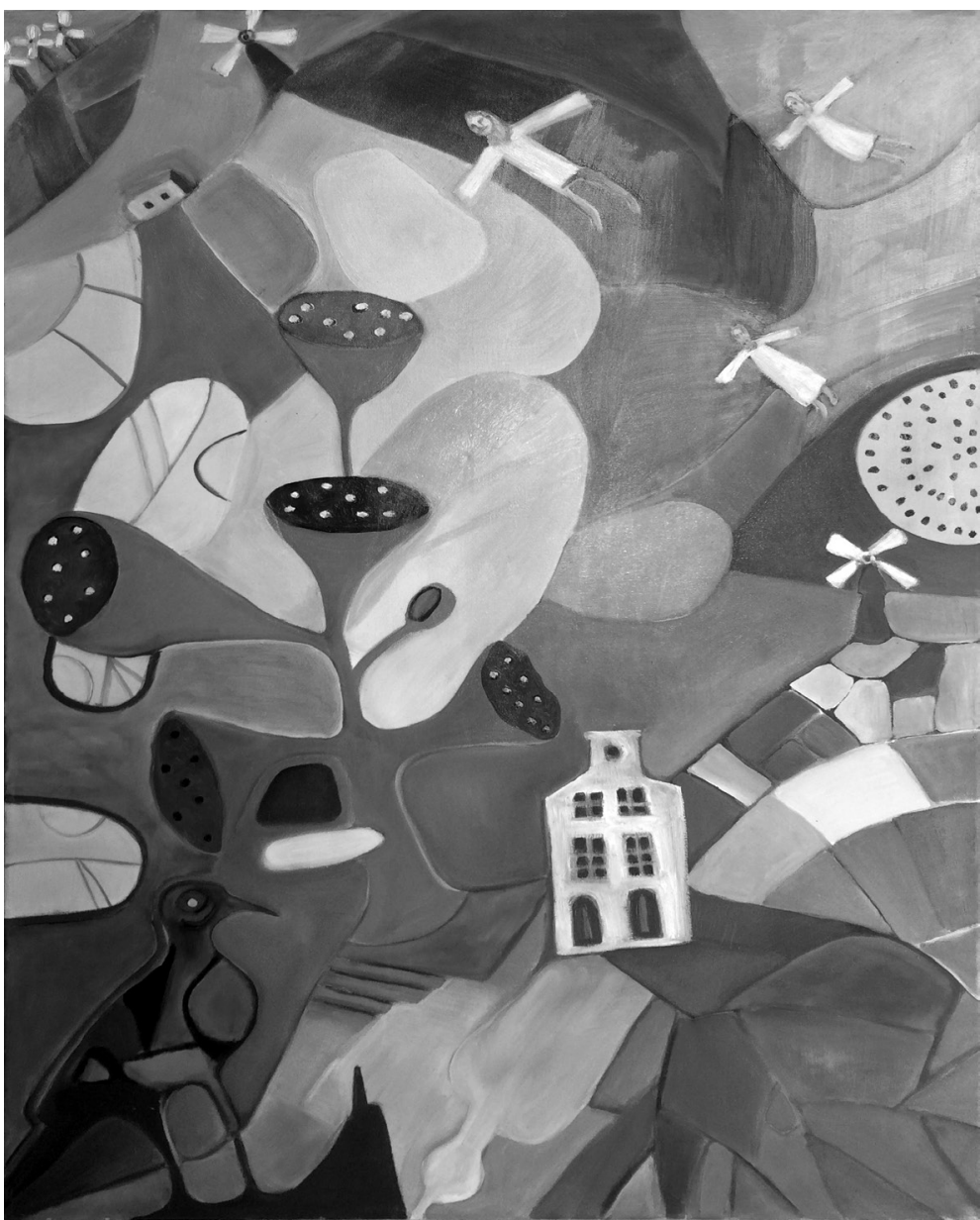

FIGURE 2. Olga Grigorjeva's painting 'Niemandsland'

(No Man's Land) featuring refugees' multiple mobilities ${ }^{27}$

The nomad does not stand for homelessness, or compulsive displacement: it is rather a figuration for the kind of subject who has relinquished all idea, desire or nostalgia for fixity. It expresses the desire for an identity made of transitions, successive shifts and coordinated changes, without an 
essential unity.

Bradotti's conceptualization of nomadic subjectivity, described above, does not stand in contrast to the refugee experience, which, in reality, is frequently characterized by homelessness, displacement, and rhythmical movements. Nomadic subjectivity is not an identity category so much as a modality that favors change over fixity. In that sense, this configuration echoes the desires of my respondents, who did not so much reject the word refugee/migrant, as the stagnant and reductive conceptualization of identity it stands for. In this way, the artist attempts to reimagining of the refugee at a representational (visual) level, but also at a semantic one. Her reconceptualization of the refugee as someone who takes flight is all the more compelling in the Dutch context because of the strikingly close semantic resemblances of the two concepts of fleeing and flight: whereas the Dutch word for refugee is vluchteling, vlucht connotes fleeing, but it can also mean flight in general, or airborne movement. Grigorjeva's representational reconfiguration also signifies a semantic shift entailed in attempts to dislodge the refugee label from its overdetermined and static context. It should be noted that working through a visual artistic medium enables her to approach the topic of labelling from a level that is abstract and discursive, which allows a certain creative and conceptual distance that is not immediately available to the other respondents, whose negotiations of the refugee label occur at a more immediate personal level. Nevertheless, all the respondents' views represent a negotiation of ideologically charged terminology. 


\section{Concluding Remarks}

Drawing on the political moments of September I I and those that followed it, Jacques Derrida ${ }^{28}$ (2004, I05) advocates the destabilization of static and violent ideological terminology as an act of political resistance:

Semantic instability, irreducible trouble spots on the borders between concepts, indecision in the very concept of the border: all this must not only be analyzed as a speculative disorder, a conceptual chaos or zone of passing turbulence in public or political language. We must also recognize here strategies and relations of force. The dominant power is the one that manages to impose and, thus, to legitimate, indeed to legalize (for it is always a question of law) on a national or world stage, the terminology and thus the interpretation that best suits it in a given situation.

Language can become a border apparatus that must be challenged through interventions in the discursive logic of certain practices that simultaneously reflect cognizance of the institutional power underlying the dominant terminology. As revealed by the case studies in this chapter, the endeavor by individuals to destabilize the conceptual cluster of the refugee/migrant/asylum seeker is difficult to accomplish in practice because the rejection of one ideological category not infrequently means replacing it with another. Thus, for instance, the refugee label may be shed in favor of a cosmopolitan notion of the refugee. However, these personal strategies and modes of self-definition also point to the inherent need of those labelled as refugees to construct categories of their own, and in doing so, these individuals seek to shift the category of

28 Derrida $(2004,93)$ attends to how discourse, viewed as an apparatus, operates through "a combination of public opinion, the media, the rhetoric of politicians and the presumed authority of all those who, through various mechanisms, speak or are allowed to speak in the public space" thus instilling a certain norm that becomes naturalized and, in this case, operates according to a lexicon of violence. 
refugee from a marginal to a more central position within discourse and society. The cosmopolitanization of the refugee label therefore emerges as an ambivalent phenomenon, signifying both the reiteration of a relatively closed conceptual category as well as the possibility for producing a more expansive notion of subjectivity. But beyond this, the responses analyzed also point to social and political processes through which migration is being framed as a threat, invasion or simply Other in the contemporary European context.

In conclusion, I want to point to the original conflict that spurred me to write this paper. This chapter represents my aspiration, fueled by the sentiments expressed by the majority of my respondents, to do justice to the specificities and complexities of migratory experiences that oftentimes are lost when the above labels are invoked. The issue here is not simply that the "migrant" and "refugee" labels are reductive signifiers, although my paper focuses on representation and discourse in particular. Luman and Vuoristo (2015) make the connection between (public, popular) discourses, policies, and rising support for anti-immigration parties across Europe in light of the ongoing "migration crisis." Pointing to research that links negative public opinion to increased securitization of borders and a growing affiliation with right-wing politics, these authors illustrate how the framing of migration hinges on different contexts (popular, political, legal, and cultural) that reinforce and co-constitute each other. In other words, there is a feedback loop between the way we conceptualize and talk about migration and how governments deal with migrants. Moreover, as Hovil (20I6) points out, the practice of labelling migration frequently overlooks "the multiple ways in which refugees forge spaces of belonging in ways that often contradict - or even subvert - national and international policies." That is to say, the lived realities of migration are far more complex and contradictory than the popular/legal/political terms "migrant" or "refugee" suggest. Therefore, nuancing and destabilizing these meanings is a pressing political question.

\section{Works Cited}


- Ahmed, Sara. 2004. The Cultural Politics of Emotion. London: Routledge.

- Althusser, Louis. I 97 I. "Ideology and Ideological State Apparatuses." In Lenin and Philosophy and other Essays, ed. Louis Althusser, New York: Monthly Review Press: I 27-i 86.

- Anderson, Benedict. I991. Imagined Communities. Reflections on the Origin and Spread of Nationalism. London: Verso.

- Bhambra, Gurminder K. 2or6a. "Whither Europe?” Interventions, i 8 (2): I $87-202$.

- Bosma, Ulbe. 20 1 2. Post-Colonial Immigrants and Identity Formations in the Netherlands. Amsterdam: Amsterdam University Press.

- Braidotti, Rosi. 2o r r. Nomadic Subjects. Embodiment and Sexual Difference in Contemporary Feminist Theory, and edition, New York: Columbia University Press.

- Coleman, Matthew. 20r 2. "The 'Local' Migration State: The Site-Specific Devolution of Immigration Enforcement in the U.S. South." Law E Policy 34(2): I 59-90.

- Derrida, Jacques. I992. The Other Heading. Bloomington: Indiana University Press.

- Derrida, Jacques. 2004 [2001]. "Autoimmunity: Real and Symbolic Suicides." In Philosophy in a Time of Terror: Dialogues with Jürgen Habermas and Jacques Derrida, ed. Giovanni Boradori, Chicago: University of Chicago Press: $85-136$.

- Essed, Philomena, and Isabel Hoving. 20 I 4. "Innocence, Smug Ignorance, Resentment: An

- Introduction to Dutch Racism." In Dutch Racism, ed. Philomena Essed and Isabel Hoving. Amsterdam: Rodopi B.V: 9-30.

- Ghorashi, Halleh. 20r4. "Racism and 'the Ungrateful Other' in the Netherlands." Thamyris/Intersecting 27: IOI - I6

— Gusterson, Hugh. I 997. "Studying Up Revisited.” PolAR 20(I): I I 4- I I 9.

- Harindranath, Ramaswami. 2008. "Refugee Experience, Subalternity, and the Politics of Representation." In Communications, Civics, Industry. Australia New Zealand Communications Association Conference refereed proceedings, J. Tebbutt (ed.): $\mathrm{I}-8$.

- Hovil, Lucy. 2016. "Refugees, Conflict and the Search for Belonging." Retrieved 6 March 2018 from http://citizenshiprightsafrica.org/ refugees-conflict-and-the-search-for-belonging-2/.

- Jones, Guno. 20r4. "Just Causes, Unruly Social Relations. UniversalistInclusive Ideals and Dutch Political Realities." In Revisiting Iris Marion Young on Normalisation, Inclusion and Democracy, ed. Ulrike M. Vieten, 67-86. London: Palgrave MacMillan.

- de Leeuw, Marc, and Sonia van Wichelen. 20r 2. "Civilizing Migrants: Integration, Culture and Citizenship. European Journal of Cultural Studies I 5(2): I 95-2 IO.

- Longinović, Tomislav. 201 8. "The Migrant Crypt: Cultural Translation Across 
the Balkans", Interventions, 20(6): 890-905.

- Luhman, Meghan and Vuoristo, Kaisa. 2015. "Framing Migration: Rhetoric and Reality in Europe - An Introduction.” Retrieved I 2 January 2018 from http://critcom.councilforeuropeanstudies.org/ framing-migration-rhetoric-and-reality-in-europe-an-introduction/.

- Magnusson, Nicola. 20 I r. "Refugeeship - A Project of Justification. Claiming Asylum in England and Sweden.” Ph.D. Dissertation. Stockholm: Stockholm University.

- Malkki, Liisa H. I 996. "Speechless Emissaries: Refugees, Humanitarianism, and Dehistroicization. Cultural Anthropology, I (3), 377-404.

- Mepschen, Paul. 20r6 "Everyday Autochthony: Difference, Discontent and the Politics of Home in Amsterdam." Ph.D. Dissertation. Amsterdam: Amsterdam University.

- Nader, Laura. I 972. "Up the Anthropologist: Perspectives Gained From Studying Up." In Reinventing Anthropology, ed. Dell Hymes, 284-3 I I. New York: Pantheon Books.

- Ponzanesi, Sandra, and Bolette B. Blaagaard. 20 i r. "In the Name of Europe." Social Identities: Journal for the Study of Race, Nation and Culture I7(I): I - Io.

- Szczepaniková, Alice. 2008. Constructing a refugee: the state, NGOs and gendered experiences of asylum in the Czech Republic. $\mathrm{PhD}$ thesis, University of Warwick.

- Smith, Justin E. H. 2014. "Does Immigration Mean 'France is over'?” New York Times, 5 January.

- Wekker, Gloria. 2016. White Innocence. Paradoxes of Colonialism and Race. Durham, NC: Duke University Press.

- Zetter, Roger. I 99r. "Labelling Refugees: Forming and Transforming a Bureaucratic Identity." Journal of Refugee Studies 4(I): 39-62.

- Zetter, Roger. 2007. "More Labels, Fewer Refugees: Remaking the Refugee Label in an Era of Globalization." Journal of Refugee Studies 20(2): 1 72-92. 


\section{ARTICLE 3}

\section{On this path to Europe" - the Symbolic Role of the 'Balkan corridor' in the European Migration Debate}

Published in the edited volume Cultures, Citizenship and Human

Rights (eds. Buikema, Buyse \& Robben). Routledge, 2019.

\section{Introduction}

Addressing the European Committee of the Regions on October Io, 2017, Donald Tusk, President of the European Council proclaimed: "By ordering the closure of the Western Balkan route and improving our cooperation with Turkey, the flows of irregular migrants on this path to Europe were stemmed by 98 per cent" (Address by President). The Western Balkan route, more popularly known as the Balkan corridor, was a relatively short-lived phenomenon and represented a part of an unofficial migration route for refugees/forced migrants traveling from Turkey and Greece to countries in Western Europe (mainly Germany) from autumn 2015 until spring 2016. The route, starting in Turkey, went through Greece and Macedonia after which followed the Balkan corridor - consisting of different points in Serbia, Hungary, Croatia and Slovenia - and from there it continued into Austria, Germany and other countries in Western Europe that represented (more) permanent points of arrival (Arsenijević et al. 20I7, 2). In this respect, Tusk's statement highlights the idea that the countries on this particular migration route, and especially the countries that made up the Balkan corridor, do not constitute Europe per se but rather represent an entry point to Europe. Being Europe-adjacent, these countries represent a frontier of sorts, a contested terrain where notions of Europeanness are unstable and unstraightforward. Tusk's statement implies that the countries that made up the Balkan corridor do not belong properly to Europe, but 
neither are they fully outside of Europe. The idea that the countries in the Western Balkans take up an ambivalent position in the European imaginary was amplified when the Balkan corridor was in full effect, as it represented an influx of Otherness in symbolic and concrete terms.

At the outset, the route along the Balkan corridor had a relatively open character, and it was unique in the sense that the movement of forced migrants and refugees was not regulated by human smugglers but by the EU and non-EU states that found themselves on the route. Although not in compliance with $\mathrm{EU}$ law ${ }^{29}$, the formation of a relatively safe passage through the Western Balkans to other destinations in Western Europe was supported by the EC and many EU countries initially, and it was understood that the countries along the route would not represent places of permanent settlement but rather that they would have a transitory character (Sardelić 2017,3 ). However, quickly after it was established, the route saw increasing institutionalization from the countries that made up the corridor, as well as the militarization of borders and segregation policies that were to distinguish between 'legitimate' and 'illegitimate' refugees (Moving Europe 2016). On March I8, 20r6, the EU-Turkey Statement ${ }^{30}$ was introduced, effectively shutting down the migration route through the Western Balkans and the Balkan corridor as such. The introduction of the EU-Turkey Statement is presented by the European Commission as a means to "to end the flow of

29 The Balkan corridor phenomenon stood in contradiction with the Dublin III regulation, which stipulates that member states are responsible for those asylum seekers who submit their asylum claim within the member state to which they first arrive in Europe. The Balkan corridor phenomenon was unique because the countries that found themselves along the route were understood to be a passage towards more Westward countries, like Austria and Germany, and thus the asylum seekers who took the route through the Western Balkans largely did not submit asylum claims (Sardelić 2017,3 ). After the shutdown of the Balkan route, the CJEU (Court of Justice of the European Union) would retrospectively decide that this previously tolerated passage had no legal basis in EU law (ibid.)

30 The EU-Turkey Statement stipulates that all irregular migrants making their way from Turkey to Greece are to return to Turkey; in turn, the EU will provide funds to manage the larger number of refugees that find themselves in Turkey. 
irregular migration from Turkey to the EU and replace it with organised, safe and legal channels to Europe" (EU-Turkey Statement: One Year On). This statement highlights the notion that the Balkan corridor was an aberration from the (presumably more organized) management of migration in Europe since 2015; moreover, the Balkan corridor is brought into connection with everything that the EU is not: unsafety, illegality and disorganization. These ideas are not new; in fact, there is a large discursive and historical repository of discourses which connect the idea of Western Europe with progress and civilization, whereas the notion of Europe's East, and especially the Balkan region, is envisaged as backwards and inferior (Todorova 1997; 2009). The short existence of the Balkan corridor and the subsequent measures taken to halt its operation cannot be viewed separately from the ideological framework that posits the West as "Europe proper" and the East together with the Balkans as "the Other within" (ibid.). Indeed, I argue that the Balkans' ambiguous position in the European imaginary needs to be taken into account in understanding the character of, and the response to, the migration phenomenon that took place between autumn 2015 and spring 2016 with the emergence and subsequent shutdown of the Balkan corridor. This situation needs to be placed in the wider context of the European 'migration debate' and the accompanying anxieties around the assumed influx of cultural others, as well as the fortification of borders and migration policies. The Balkan corridor, I argue, brought with it an amplification of these anxieties due to the Balkans' liminal role in the European imaginary, since a discourse of (cultural, racial, ethnic) Otherness vis-à-vis the 'true' Europe already characterizes this region. The Balkan corridor therefore needs to be assessed as a symbolic phenomenon as well, giving rise to unconscious fears of abjection by representing a potential rupture in the fiction of a unified European self, an idea that is reiterated in the sensationalist mediatization of the phenomenon and in political discourse. 


\section{Europe and the other Europe}

This chapter looks at Europe through a critical lens, rejecting the notion that the idea of Europe simply coincides with the geographic location of the continent. Rather, Europe is considered in its geopolitical and symbolic dimension as an idea or even a quality of sorts: situations, places and phenomena can be more or less 'European,' depending on the extent to which they conform to a dominant yet underacknowledged conception of Europe. Étienne Balibar has written about Europe as comprised of three concentric circles, the inner core representing the founding nations of the EU that share a single currency, while the more peripheral regions, outside of the EU, subsequently have an ambivalent placing in the idea of Europe (2009, I99). Importantly, the countries representing the European nucleus have a political and historical affinity, and so the countries that find themselves at the peripheries of Europe are not just there because of pure spatial distance but due to a cultural, political and historical difference as well, which Balibar calls a "political distance" (ibid.). Europe is therefore not a purely geographic entity, nor is it a unitary one, being made up by a multiplicity of internal divisions.

In studying the phenomenon of the Balkan corridor, in this chapter I am primarily interested in the division that splits Europe into East and West. This division did not come into being naturally nor arbitrarily but, as Larry Wolff has pointed out, it needed to be invented. Whereas prior to the Enlightenment, during the Renaissance and before, Europe was commonly understood through a North/South division, this boundary shifted to East/West and propagated a civilizational model according to which the "intellectual centers" were found in Western Europe while Eastern Europe was emerged as "shadowed lands of backwardness, even barbarism" (1994, 4). Yet, being part of the same continent, the East/ West division never was fully cemented and in fact resulted in the ambiguous situation in which Eastern Europe had the double position of being simultaneously Europe and not-Europe. Similar to the workings of Orientalism (Said 1978), the invention of Eastern Europe defined 
and legitimized the West first and foremost, but it was symbolically placed in a position between the West and the Orient. And so, as Wolff himself says "one might describe the invention of Eastern Europe as an intellectual project of demi-Orientalization" (Wolff i 994, 7). Others have critically engaged with the discursive creation of Eastern Europe, notably Maria Todorova, who rejected the notion of Orientalism but theorized a more specific concept of Balkanism, explaining how a specific discourse of inferiority and backwardness was projected by the West onto the Balkan region (Todorova I997; 2009). Elsewhere, I have written about the Balkans representing a 'failed Self,' a symbolic and discursive entity projected by the West onto this region in Southeast Europe that operates according to an uncomfortable tension between proximity and distance, inside and outside, being neither fully inside Europe nor fully outside it (Trakilović 2or6). The core of Europe then comes to be represented by the West, while its Eastern and Southern parts only partially correspond to this idea. This liminal position in the European imaginary, I argue, gained prominence during the period when the Balkan corridor was in effect, prompting its speedy and efficient closure in March 2016.

However, Europe is not only shaped by this symbolic division between the East and West. David Theo Goldberg argues that the idea of Europe is upheld by the belief that Europeans are (predominantly) white and Christian peoples (2006, 352). Moreover, he posits that Europe is built on a "historical amnesia" $(2006,337)$ which disavows how European colonial histories have had and continue to have a profound effect on European cultures and politics today. Furthermore, this historical amnesia is strengthened by the belief that the Holocaust was the pinnacle of racial violence, which happened on European soil. The Holocaust is singled out as the defining moment of racist transgression, which effectively renders other racial practices, past and present, unmentionable and invisible $(2006,336)$. This means that there is a blind spot in European societies to other, and particularly 'newer' forms of racial discrimination that are not recognized as such because of Europe's supposed internal homogeneity and race-free character. This does not 
stand in contradiction with the internal division between East and West in Europe; what is more, it supports it. Critical attention has been paid to how the supposed East/West dichotomy in Europe becomes internalized by Southeast European regions that end up reproducing this logic within their own societies, according to "internalized racial hierarchies" that target minority populations like the Roma (RuckerChang 2018, 857). Additionally, the concept of nesting Orientalisms explains how regions in Southeast Europe reproduce the tendency to Orientalize their neighbors, those who find themselves geographically and symbolically more towards the East, in an attempt to gain legitimacy in Europe proper (Bakić-Hayden 1992). Effectively, this means that while Orientalist discourses are projected onto Southeast Europe by the West, within the region itself various discursive racializations are being played out as well. I understand racialization here as the social, cultural, political and spatial creation and subsequent exclusion of Otherness, in line with what Balibar has termed "essentializing cultural difference" $(2005,3)$. This practice re-inscribes the idea that Europe is a dominantly white and Christian 'race-free' space, which legitimizes racialized discourses that are not recognized as such.

Of note here is that the history of colonialism and its racial formations which shape the dominant idea of Europe have not bypassed the postsocialist sphere, even if it had a different historical and political formation. It is important to configure race and racialization in the critical understanding of the Balkan corridor and the responses to it not only by the West/EU, but also by the Southeast European nations that found themselves on the route. In other words, if the phenomenon of migration along the Balkan corridor is to be critically assessed, one must account for "racialization of the Balkans" as well as "racialization in the Balkans" (Baker 2018, 769). This is important because it helps contextualize not only the framing of the Western Balkans according to a dominant (Western) European discourse, but also the various responses to the migration phenomenon by the countries that found themselves along the migration route of the Balkan corridor, such as Hungary and Serbia. In their various responses (whether exclusionary or benevolent) to the 
refugees making their way through this region, the countries often reproduced a racialized and culturalist idea of what 'proper' Europe is and who can and cannot belong, thereby reinstating the East/West binary. ${ }^{3 x}$

\section{Responses to the Balkan corridor}

Although the migratory trajectories in the Western Balkans in late 2015 and early 2016 are popularly referred to as a singular passage, this is an incorrect term. As Ferrucio Pastore points out, the journey through the Western Balkans could and did take different directions, and two main routes actually emerged, both starting in Turkey but diverging in either Macedonia, Bulgaria or Serbia (2019, I9). These divergent routes were largely dependent on Bulgaria and Hungary sealing off their borders in August and September 2015, respectively, which re-directed the trajectory through the former Yugoslav republics of Serbia, Bosnia and Herzegovina, Croatia and Slovenia. Pastore describes this mediation

3 I Sara Pistotnik and David Alexander Brown (2018) have noted that Slovenia's response to migration in 2015 - characterized by exclusionary measures through the implementation of barbed wire and fences - is intimately connected to what is referred to as the Erasure. In 1992, when Yugoslavia was disintegrating, Slovenia effectively erased some 25,000 people (mostly people from other Yugoslav republics) from its register of permanent residence, thereby stripping these people of citizenship and rights. The authors note how this measure was not just a way of establishing national boundaries in Slovenia but also a way of Europeanizing the country by implementing European migration policies. The Erasure is then a racial(izing) practice, and set a precedent for the measures Slovenia would implement and the position it would adopt with regard to the migration 'crisis' in 2015 when the Western Balkan migration route emerged. This development has larger implications, however. As Dušan Bjelić points out:

Underneath the EU sovereign unity looms an administrative war on immigrants as spatial - racial enemies in which the Balkans holds the frontline. By becoming a part of the EU's legal system, the Balkans cannot any longer claim colonial and racial exceptionalism. (2018, 907)

Thus, the newest EU states become somewhat of a frontline of Europe where spatial and identarian boundaries are invoked most fiercely, and they thereby participate in reproducing dominant racial ideologies that have colonial roots. 
of the route in terms of a "reckless domino game, based on a chain of "beggar-thy-neighbour" (2019, 20). The 'beggar-thy-neighbour idiom, which describes a situation in which a country tries to resolve an economic issue of their own to the detriment or through the exploitation of their neighbor(s), is significant here and needs to be assessed in dialogue with the notion of nesting Orientalisms (Bakić-Hayden I992), which explains how countries in Southeast Europe come to stereotype their neighbors in order to secure a claim to Europe proper. Hungary and Bulgaria became EU member states in 2004 and 2007, respectively. Croatia's joining is more recent, since it became a member in 2013, while Serbia is at the moment a candidate country, and Bosnia and Herzegovina only a potential candidate. During the time when the Balkan corridor was in effect, Hungary was the preferred country of transit since it is also part of the Schengen area. (¿̌uparićIjić and Valenta 2or8) Hungary's closing of the Hungarian-Serbian border through the building of a 4-meter fence was set into motion by Hungary's right-wing Prime Minister Viktor Orbán, who justified the closure of the border as a means of keeping Europe culturally and ideologically pure: "Those arriving have been raised in another religion, and represent a radically different culture. Most of them are not Christians, but Muslims. This is an important question, because Europe and European identity is rooted in Christianity" (Traynor 2019).

Orbán's quote here not only reiterates the idea that Europe is a homogenous, Christian continent, but also invokes the image of the racialized Other through the figure of the Muslim, a figure that stands in stark contradiction to a dominant European self-conception. The Muslim is "the quintessential outsider, ordinarily strange in ways, habits, and ability to self-govern, aggressive, emotional, and conniving in contrast with the European's urbanity, rationality, and spirituality" (Goldberg 2006, 345). Orbán's statement reinforces the belief that the Muslim cannot belong in Europe due to a cultural incompatibility, and this serves as a justification for removing Hungary from the Balkan corridor migration route. By closing off the Hungarian border, the migration trajectory in the Western Balkans was thus re-directed, mainly through the former 
Yugoslav states. This re-routing is thus ideologically motivated, and it also carries a symbolic dimension, as it directs the 'flow of Otherness' to the more southern states, away from Hungary, and in so doing, it also emphasizes the idea that Hungary is closer to Europe by having controlled the migrating mass and moved it away from its soil. Since the 'migration crisis' in Europe is routinely represented through the 'invading' figure of the Muslim, the potential invasion is now halted in Hungary and moved toward the south, to former Yugoslav states that represent even more ambiguous entities in Europe. Through the phenomenon of nesting Orientalisms, these states are re-Orientalized by having the invading figure on their soil in the first place, and secondly by not being able or willing to halt or control the Westward movement of migration through their territories - like Hungary did.

While Hungary adopted a strict policy in keeping its border secure during this time, other states along the migration route in the West Balkans were, perhaps surprisingly, more lenient. Serbia's Prime Minister Aleksandar Vučić's response to Hungary's border closure was one of shock and dismay, stating that, contrary to what Orbán had proclaimed, the building of the fence was expressly anti-European:

We will not allow anyone to humiliate us. I call on the European Union to react, for its members to behave in line with European values. If the EU does not react, we will find a way to protect our borders and European values as well. (Kingsley 2015)

Both Prime Ministers call on the protection of European values, but they also position themselves at different ends of the argument. Orbán makes the call from a more central position in Europe, while Vučić makes an appeal to Europe. Hungary's status as EU and Schengenzone member lends Hungary a more internal position in the European imaginary, while Serbia's status as EU candidate marks the country as more external to Europe proper. This is why the prime ministers make appeals to different European values and characteristics: Orbán's focus 
is on safeguarding the supposed racial and religious homogeneity of Europe, while Vučić speaks of hospitality and tolerance of Otherness as a European trait that should be upheld in the migration debate. This may come as somewhat of a surprise, since the disintegration of Yugoslavia in the early I990s was characterized by very strong ethno-nationalist sentiments in the resulting nation states; in Serbia in particular, an explicit anti-Muslim rhetoric was mobilized to justify the violent conflict with Bosnia and Herzegovina and later on Kosovo as well. However, this rhetoric was notably absent in Serbia's official response to the migration corridor in the Western Balkans, while it was explicitly present in Hungary's attitude. Tomislav Z. Longinović astutely assesses this puzzling situation:

Through this sudden role reversal, the symbolic boundary supposedly representing "Christian values" has been moved to the north, where the Hungarian border functions as the European one. Paradoxically, it appears that being part of Europe proper gives license to its constituents for xenophobia and racism, while being at the very threshold of the EU pushes its potential members to display adherence to alleged European ideals and values, forcing them to perform (if frequently inauthentic) openness and humanity towards all nations and religions. (2018, 897)

Although they found themselves along the same migration route, there was a difference in how each nation in question responded to the phenomenon. Consequently, Hungary could permit to close its borders and express anti-migrant sentiment because it is part of the official European framework, as represented by the EU and the Schengenzone. On the other hand, Serbia and similar non-EU countries could not permit to express anti-migrant sentiment because of their precarious position in the official European political structures, and therefore they performed an openness to difference in accordance with supposed core European values as well. What should be kept in mind here is 
that both responses may have a very similar discursive effect: namely, reinstating the idea of Europe as a unique and privileged place, a civilizational model. While their rhetoric differs, both Hungary and Serbia are performing Europeanness in an attempt to come closer to Europe proper, which is always already located elsewhere, namely in the West. Once again, "The fate of European identity as a whole is being played out in Yugoslavia and more generally in the Balkans (even if this is not the only site of its trial)" (Balibar 2004, 6).

\section{The Balkan corridor as a confrontation with abjection}

The phenomenon of the Balkan corridor, characterized by "irregular" migration, was treated as a state of alarm during the time that it was still in operation. This is evidenced by the emergency meeting that was held in Brussels on October 20, 2015, at which eight EU member states and three candidates were present in order to draw up a plan of action that would manage and control the Westward migration movement. With time passing, the passage through the corridor became more and more regulated and controlled, whether through the closing of physical borders (such as the Hungary-Serbia case) or whether it was through the management and control of the unruly migrating mass. In November 2015 , states began to segregate the migrating groups into 'legitimate' (Syrians, Afghans and Iraqis) and 'illegitimate' migrants. Those deemed illegitimate were no longer allowed access through the corridor (Moving Europe 20I6) In other words, border management was introduced on several interconnected levels in order to halt the progression of the corridor. Ponzanesi and Blaagaard have argued that in present-day Europe, borders are undergoing a shift,

moving from physical (the gate to European territories and citizenship) and symbolic (the myth of Europe and its idea of superiority) to material borders (the marked body of foreigners, immigrants and asylums seekers) which become "border" 
figurations (construction of otherness, foreignness, alienness). $(2011,3)$

In the case of the Balkan corridor, the border was indeed enacted upon those moving subjects who were racialized as Other and therefore as a threat to Europe. At the same time, I believe that a more complete understanding of the phenomenon of the Balkan corridor needs to consider the interconnected ways in which physical, symbolic and material borders emerged simultaneously and co-constructed each other. Thus, the erecting of physical borders was a result of the desire to maintain symbolic borders of Europe that were seen to be under threat by the invading figure of the migrant Other, representing the material border. The complex ways in which border management was enacted within the phenomenon of the Balkan corridor needs to be understood in symbolic terms as well as a confrontation with abjection.

In popular and political discourse, migration in Europe is frequently framed as a threat and the migrant subject is considered as an Other to the European identity. This figure is racialized and popularly imagined as the Muslim Other, which becomes a trope that is meant to distinguish between Europeans and migrants (E1-Tayeb 20I I, xxx); the workings of this trope were clearly visible in the previously discussed quote by Viktor Orbán. Moreover, in the current political moment, it is quite common to envision migration in terms of metaphors denoting a natural phenomenon, as a wave or a stream that intrudes upon the continent. Framing migration in such a way, as David Cisneros points out, is a selective process, representing both a 'reflection' and 'deflection' of reality; thus, metaphors of immigration close off other possibilities for understanding immigration" $(2008,592)$. I mention these examples because they are, as I will further argue and expand on, the workings of abjection; an obsessive need to characterize the Other as Other in order to justify its removal from European soil.

Feminist psychoanalyst Julia Kristeva (1982) has theorized the abject as that which threatens to collapse the borders that hold the self 
together. However, the abject should not be understood as being external to the self. Rather, the self can only exist as such by expelling the abject from its own being, thereby maintaining the illusion of separation and a unitary identity. And yet, the self can only exist by virtue of the abject, which it consequently needs to expel in order to establish the ultimately porous boundaries of its identity. Identity, individual and collective, is in this sense configured due to the constant externalization of an undesirable element that, once expelled, is then made into an absolute Other: the abject. The process of abjection is never finished and what is more, a unitary idea of identity is only possible due to the continual externalization of an abject that ultimately delineates the borders of that very same identity. The Self then only comes into being by virtue of the difference that is established through abjection; the implication being that the idea of the Self would not exist in itself since it is dependent first and foremost on the idea of the Other (who comes into being through the process of abjection) against which it can measure itself. The Self needs the Other to exist, in other words, but it also needs to keep the Other at bay, since its assimilation would threaten the very conception of identity that the Self has established. The notion of the abject signifies this constant process of externalization through which the Other comes into being, but also the porosity of the borders around the Self. ${ }^{32}$ The abject therefore constantly threatens to collapse the walls upon which the idea of the self is built and, most importantly, the self needs to operate according to the illusion of control over the abject in order to establish its identity. The abject is invoked in those instances when the supposed

32 Abjection can also be understood as a bodily dynamic. In that sense, the Self is first and foremost a body that can be hurt, invaded and diseased by the workings of abjection. The configuration is a trope that is often used in nationalist discourse: envisaging the nation as a body that can be potentially compromised. As Gaia Guiliani writes, "The (human) body as well as the body politic are in danger and need to be eugenically preserved from hordes of aliens that, like a mortal disease, have to be eradicated from the healthy corpus of European nations" (2016, 99). The Self-Other dynamic according to which abjection functions becomes even more evocative through the metaphor of the (European) nation as a healthy body and the migrant as an invading disease. 
borders around identity are threatened to be compromised. According to Kristeva, the abject is that which "disturbs identity, system, order. What does not respect borders, positions, rules. The in-between, the ambiguous, the composite" (1982, 4). I propose the theory of abjection as a key concept in assessing Europe's response to the 'migration crisis' in relation to the phenomenon of the Balkan corridor. Abjection in this case was present in two interrelated ways: through the liminal position of the Balkans in the European imaginary and through the large number of non-European migrants and refugees that made use of the Balkan corridor. Both represented a threat, or a looming collapse of the European identity.

Kaiama Glover, writing on the 'zombification' of Third World subjects, with a focus on Haitians and Sub-Saharan Africans, explains how popular and political discourse creates the figure of the First World citizen as ontologically different and distanced from a pathologized Third World subject. Moreover, she considers how this distancing mechanism works through the principle of abjection that is predicated on making foreign certain groups and peoples whose removal is subsequently legitimized. She says:

While we tend to attribute our obsessive literal and metaphorical wall building to xenophobia, that is, an irrational fear of the foreign, it is perhaps more accurate to understand the effortful dissociation of the First World "self" from the Third World "other" as a perfectly rational fear of the same. (Glover 20I7, 250)

Drawing on the theory of abjection as well, Glover makes the point that abjection as a process, according to Kristeva, never actually consists of the subject's complete separation from that which it seeks to expel. Rather, abjection exists in the subject's continuous state of anxiety over the perceived threat of its autonomy by the abject, and this anxious state then justifies the borders it erects in an attempt to lay claims to a singular identity $(2017,249)$. In the context of today's Europe, the abject 
is constituted by migration, which represents a threat to the idea of Europe and prompts the reaction of "repeatedly making the Different different so as to sustain the Same"(Goldberg 2006, 357). Pathologizing the migrant as deviant and culturally different is then an attempt to erect an image of the self that is elevated and enlightened. Moreover, in order to protect the European identity, myriad infrastructural control mechanisms are introduced in order to manage and control the perceived threat of migration. In the context of the Balkan corridor, this was evidenced by the fact that the emergency summit in Brussels in October 2015 resulted in a I7-point action plan, put forward by the leaders of the European countries affected by the route. This plan consisted of multiple strategies aimed at curbing, controlling, managing and monitoring the migration flow through the Western Balkans; the action point that was the most extensive consisted of different strategies aimed to "Increase efforts to manage borders" (Meeting on the Western Balkans 2015). All of this was aimed at getting a grip over the migrating subjects making their way through the Western Balkans to the more Westward destinations in Europe. Migrants in Europe today are to a large extent subjected to "abjectification [. . . ] the state of often marginalised groups, bodies excluded by law and through law, who eventually become repulsive to society at large" (Lazaridis 2015, 7). The mechanisms of Othering that were placed upon the migrating subjects through discursive (narratives of inferiority, difference and pathology) and institutional/structural means (border control and management) were all mobilized in order to protect and highlight the idea of Europe, an elevated and culturally specific European identity. As Kristeva argues, "abject and abjection are my safeguards. The primers of my culture" $(1982,2)$. The idea of Europe never emerges as strongly as when its existence is perceived as being threatened by the abject migrant.

However, my argument is not only based on understanding migration as a confrontation with abjection in Europe in light of the migration crisis. Abjection is also to be understood in light of the fact that the migration route through the Western Balkans occurred on a territory that already has an ambiguous position in the European imaginary, 
neither fully inside nor fully outside Europe. The Balkans already represent a liminal entity in Europe and therefore arguably a confrontation with abjection, which was only amplified further by the migrating subjects who made their way through this region on their way to Europe. Previously, I had written about the Balkans ambiguous positioning in the European framework turning the traditional Orientalist binary of Self-Other into a more complex configuration of "the other within" (Todorova 1997; 2009) or the "failed Self" (Trakilović 2016). This position of being in-between, at once inside and outside of Europe, can have a critical potential for interrogating the boundaries (symbolic, material, institutional) that make up Europe in the first place. (Trakilović 2or6). Importantly, the Balkans are not a set place that one can point to: this is where Europe ends and the 'other Europe' begins. Rather, it is the unclear and constantly shifting boundary between Europe and not-quiteEurope, as represented by the Balkans, that characterizes the workings of abjection. As Kristeva ${ }^{33}$ notes: "We may call it a border; abjection is above all ambiguity. Because, while releasing a hold, it does not radically cut off the subject from what threatens it - on the contrary, abjection acknowledges it to be in perpetual danger" (1982, 9). The Balkans therefore are not just ambiguously placed in the European imaginary, but they signify a cultural and civilizational inferiority that could spread to, and subsequently corrupt Europe proper. This idea is of course only amplified by the 'invasion' that irregular and uncontrolled migration along the Balkan corridor represents; a double threat. With the implementation of the EU-Turkey deal, the workings of abjection as represented by

33 Dušan I. Bjelić has developed a critical argument on Kristeva's own political positioning as being predicated on a pathologization of the Balkans, especially her native Bulgaria, in order to align herself better with the cosmopolitan West, particularly France, where she completed her academic trajectory $(2009,499)$. Kristeva has also been known to express anti-migrant sentiment in the French context, disregarding the complex history of French coloniality. Interestingly, Kristeva's personal positioning involved an abjectification of the Balkans and immigrants both in an attempt to embody 'proper' European (read: Western) subjectivity. The importance of her theory of abjection notwithstanding, Kristeva's own rhetoric and political alignment shows how the Balkans and the migrant are already abject configurations in the dominant European imaginary. 
both the figure of the migrant and the space of the Balkans were not halted but rather separated from functioning together, and in this way they were 'diffused.' However, the migrant and the Balkans both remain peripheral and thus abject configurations in the dominant European imaginary, which remains largely unchallenged.

\section{Conclusion}

This chapter has outlined how the highly mediatized and politicized phenomenon of the 2015-2016 Balkan corridor functioned in its symbolic dimension as an accelerated confrontation with abjection. Focusing on the symbolic role of the Balkan passage in particular and the European migration 'crisis' in general is useful in understanding the oftentimes competing political discourses (focused on openness and tolerance of difference on the one hand, and exclusion and cultural and border protection on the other hand) as ultimately reproducing the same idea of European/EU exceptionalism. While the chapter has mainly focused on political discourse and actions, these need to be understood as always already intimately intertwined with processes of mediatization. Indeed, as Michał Krzyżanowski et al. argue, the notion of the "refugee crisis," politicized and mediatized as it has been in recent years, is not an arbitrary construct but one that mobilizes political, institutional and economic infrastructures in Europe towards securitization $(2018,3)$. Moreover, the overwhelming politicization of (im)migration in Europe goes hand in hand with the mediatization of politics, which results in a situation of "mediated hegemonic political control" $(2018,6)$.

This political control is exercised through a bordering process that is both material (consisting of the implementation of 'actual' borders and border mechanisms) and discursive (symbolic processes of othering). Due to the ambiguous position that the Balkans hold in the Europe, the aforementioned politicization of the refugee 'crisis' was accelerated in the debate surrounding the phenomenon of the Balkan corridor as it represented an amplified confrontation with Otherness. 
Considering the anxious reactions to, and subsequent shutdown of, the Balkan corridor through the theory of abjection helps to understand the underlying desires and drives that facilitated the foreclosure of this particular migration route as "psychosocial fantasies of distance in the midst of proximity" (Glover 2017, 249). A particular idea of Europe, largely coinciding with the EU/the West, emerges as a configuration of Self against which an abject Other is posited: disavowing this Other from European soil nevertheless does not destroy the idea of the Other, since its configuration is necessary for the Self to define itself against. The figure of the migrant and the imagined space of the Balkans are examples of such abjected entities. If abjection is the "primer of my culture" (Kristeva I982, 2), which culture are we talking about then? What emerges from this analysis is a Eurocentric ideal that can manifest in different discursive tropes.

One of these discursive tropes is Balkanism, which posits that the region corresponding to the Balkans represents an undesirable, backwards and culturally inferior entity in Europe and therefore does not properly belong to Europe. This is echoed in Donald Tusk's proclamation that the Western Balkans migration route represents a path "to" rather than in Europe. As Catherine Baker notes: "Time's arrow, in these symbolic geographies, should typically be pointing the region toward 'Europe,' where it can leave the Balkans behind" (2018, 76r). The Balkans are spatially and temporally 'behind' Europe proper, which is signified by the West/the EU.This sentiment is also echoed in the fact that the Western Balkans migration route was popularly and colloquially referred to as the Balkan 'passage' or 'corridor,' signifying the transitory character of the region as a stepping stone to Europe. Furthermore, these sentiments were echoed in the various statements that were made by the political leaders of the countries that were along the Western Balkans migration route and in the subsequent strategies that were adopted for the purposes of controlling or keeping out migrants and refugees on the route. Their responses are intimately connected to the position that the countries they represent already hold in the official European framework, so that "Central European countries were embracing xenophobia 
and open racism, while the countries on the outskirts of the European Union were, at least officially, perpetuating 'European' principles of universal human rights" (Longinović 2018, 904). Ultimately, however, these discourses reinstate the idea of European exceptionalism and mobilize it through the racialized figure of the migrant as culturally inferior, and therefore exterior to Europe. The emergence of the migration route along the Balkan corridor and the frenzied reaction it prompted therefore need to be understood as a re-inscription of the idea of a European Self in relation to this phenomenon. 


\section{Works Cited}

- Address by President Donald Tusk to the European Committee of the Regions. European Council, Io Oct. 2017, www.consilium.europa.eu/en/press/ press-releases/2017/ro/ro/tusk-committee-regions/. Accessed 2 I Jan. 2019.

- Arsenijević, Jovana, et al. "A Crisis of Protection and Safe Passage: Violence Experienced by Migrants/Refugees Travelling along the Western Balkan Corridor to Northern Europe." Conflict and Health, vol. I I, no. 6, 20I7. https://conflictandhealth.biomedcentral.com/track/pdf/Io.I I86/ si3O3I-OI7-oro7-z.

- Baker, Catherine. "Postcoloniality Without Race? Racial Exceptionalism and Southeast European Cultural Studies." Interventions, vol. 20, no. 6, 2018, pp. $759-784$.

- Bakić-Hayden, Milica, and Robert Hayden. "Orientalist Variations on the Theme "Balkans": Symbolic Geography in Recent Yugoslav Cultural Politics." Slavic Review, vol. 5 I, no. I, I992, pp. I - I5.

- Balibar, Étienne. "At the Borders of Europe." We, the People of Europe?: Reflections on Transnational Citizenship, Princeton UP, 2004, pp. I - Io.

- Balibar, Étienne. "La construction du racism" - "The Construction of Racism.” Actuel Marx, vol. 2, no. 38, 2005, pp. I I - 28.

- Balibar, Étienne. "Europe as Borderland." Environment and Planning D: Society and Space, vol. 27, no. 2, Apr. 2009, pp. I90-215. doi:I0.1068/dI3008. The Alexander von Humboldt Lecture in Human Geography. Lecture given at University of Nijmegen, The Netherlands.

- Bjelić, Dušan I. "Immigrants as the Enemy: Psychoanalysis and the Balkans' Self-Orientalization.” The Slavonic and East European Review, vol. 87, no. 3 , 2009, pp. 488-5 I7. JSTOR, www.jstor.org/stable/40650409.

- Bjelić, Dušan I. "Toward a Genealogy of the Balkan Discourses on Race." Interventions, vol. 20, no. 6, 2018, pp. 906-929.

- Cisneros, J. David. "Contaminated Communities: The Metaphor of 'Immigrant as Pollutant' in Media Representations of Immigration." Rhetoric E Public Affairs, vol. I I, no. 4, 2008, pp. 569-60г. Project MUSE, doi:Io.I353/rap.0.0068.

- El-Tayeb, Fatima. European Others: Queering Ethnicity in Postnational Europe, U of Minnesota P, 201 I.

- EU Turkey Statement - One Year On. European Commission, I7 Mar. 2017, https://ec.europa.eu/home-affairs/sites/homeaffairs/files/what-we-do/policies/european-agenda-migration/background-information/eu_turkey_statement_I7032017_en.pdf. Accessed 2r Jan. 2019.

- Glover, Kaiama L. 2017. “Flesh like One's Own': Benign Denials of Legitimate Complaint." Public Culture, vol. 29, no. 2 (82), 2017, pp. 235-26o.

- Goldberg, David Theo. "Racial Europeanization." Ethnic and Racial Studies, vol. 29, no. 2, 2006, pp. 33I-364.

- Guiliani, Gaia. "Monstrosity, Abjection and Europe in the War on Terror." Capitalism Nature Socialism, vol. 27, no. 4, 2016, pp. 96 - I 4 . 
- Kingsley, Patrick. "Refugee Crisis Escalates as Migrants Break Through Hungarian Border." theguardian.com, The Guardian, I6 Sept. 2015, www. theguardian.com/world/2015/sep/r6/refugee-crisis-escalates-as-people-break-through-hungarian-border. Accessed 25 Jan. 2019.

- Kristeva, Julia. Powers of Horror: An Essay on Abjection. Translated by Leon S. Roudiez. Columbia UP, 1982.

- Krzyżanowski, Michał, et al. "The Mediatization and the Politicization of the "Refugee Crisis" in Europe." Journal of Immigrant \& Refugee Studies, vol. I6, nos. I-2, 2018 , pp. I - I 4 .

- Lazaridis, Gabriella. International Migration into Europe. From Subjects to Abjects. Palgrave Macmillan, 2015.

- Longinović, Tomislav Z. "The Migrant Crypt: Cultural Translation Across the Balkans." Interventions, vol. 20, no. 6, 201 8, pp. 890-905.

- "The Long Year of Migration and the Balkan Corridor. How European Narratives are Being Challenged by Migration Movements." Moving Europe. 28 Sept. 20I6, www.opendemocracy.net/en/mediterranean-journeys-in-hope/ long-year-of-migration-and-balkan-corridor.

- Meeting on the Western Balkans Migration Route: Leaders Agree on I7-point Plan of Action. European Commission - Press release, ${ }_{2}$ Oct. 2015, http:// europa.eu/rapid/press-release_IP-I5-5904_en.htm. Accessed 2I Jan. 2019.

- Pastore, Ferruccio. "From Source to Corridor: Changing Geopolitical Narratives about Migration and EU-Western Balkans Relations." Journal of Balkan and Near Eastern Studies, vol. 2 I, no. I, 2019, pp. I I-26. doi:10.1080/ I9448953.2018.1532683.

- Pistotnik, Sara, and David Alexander Brown. "Race in the Balkans: The Case of Erased Residents of Slovenia." Interventions, vol. 20, no. 6, 2018, pp. $832-852$.

- Ponzanesi, Sandra and Bolette B. Blaagaard. "In the Name of Europe." Social Identities, vol. I7, no. I, 201 I, pp. I - ro.

- Rucker-Chang, Sunnie. "Roma Filmic Representation as Postcolonial "Object"." Interventions, vol. 20, no. 6, 2018, pp. 853-867.

- Said, Edward W. Orientalism. Pantheon Books, 1978.

- Sardelić, Julija. "The Western Balkan Route: A New Form of Forced Migration Governance in Europe?” Green European Journal, 3 I Aug. 2017, www.greeneuropeanjournal.eu/the-western-balkan-route-a-new-form-offorced-migration-governance-in-europe.

- Todorova, Maria. Imagining the Balkans. I997. 2nd ed, Oxford UP, 2009.

- Trakilović, Milica. “The Other Within': Challenging Borders from the European Periphery." Postcolonial Transitions in Europe: Contexts, Practices and Politics, edited by Sandra Ponzanesi and Gianmaria Colpani, Rowman \& Littlefield International, 2016, pp. 209-228.

- Traynor, Ian. "Migration Crisis: Hungary PM Says Europe in Grip of Madness." theguardian.com, The Guardian, 3 Sept. 2015, www.theguardian. com/world/2015/sep/o3/migration-crisis-hungary-pm-victor-orban-europe-response-madness. Accessed 5 Feb. 2019. 
- Wolff, Larry. Inventing Eastern Europe. The Map of Civilization on the Mind of the Enlightenment. Stanford UP, r994.

- Župarić-Iljić, Drago, and Marko Valenta. "Refugee Crisis' in the Southeastern European Countries: The Rise and Fall of the Balkan Corridor." The Oxford Handbook of Migration Crises, edited by Cecilia Menjívar, et al. Oxford UP, 2018 , pp. 367-388. 


\section{ARTICLE 4 \\ Passing through: Negotiating Identity, Sexuality and Movement in Ahmed Imamović's Go West}

Published in special issue on Cinemas in Europe

(eds. Ponzanesi \& Berger) in Transnational Cinemas, 2016.

\section{Abstract}

Bosnian director Ahmed Imamović's 2005 film Go West, situated at the breakout of war in Bosnia and Herzegovina during the disintegration of Yugoslavia, follows an ethnically mixed gay couple as they attempt to escape war and gain entry to Europe. While hiding out in a small village in eastern Bosnia, Milan has his partner Kenan dress as a woman so that they can 'pass' as a married heterosexual couple. The notion of 'passing' and 'passing through' are some of the key themes in the film and will be the focal point of my analysis. My claim is that Go West's emphasis on a 'good' and 'bad' Europe lacks an intersectional understanding of power relations and directly influences the scope of (im)possible identities and sexualities that are presented in the film. Moreover, looking at how identity and sexuality are constructed and mediated in the film through the lens of 'nesting orientalisms' and 'Balkanism,' my aim is to bring to light an ideological duality that is created between the idea of a peaceful, liberated Europe and another Europe that always lags behind the West.

\section{Introduction}

Go West: this imperative indicates the need to move, but not merely in any direction: if one is Going West, one is also presumably Leaving East, North or South. Going West in the context of this article represents a 
yearning for a better life, peace and freedom. If placed in the context of the disintegration of Yugoslavia in the early r99os, Going West can be understood as an endeavor by the former republics of Yugoslavia to create new, distinct national identities by distancing themselves from a socialist past and adopting a 'look toward Europe', manifesting most concretely in gaining entry to the European Union. ${ }^{34}$

This desire to move from East to West is emphasized in the film entitled Go West, which came out in 2005 and was directed by Ahmed Imamović, a Bosnian director and screenwriter. At the time of its cinematic debut, the film caused a large media uproar in Bosnia and Herzegovina, and was even deemed blasphemous for its portrayal of an ethnically mixed homosexual couple in war-time Bosnia. Curiously, the outrage died down fairly quickly after the film was released (Moss 2012 , 364). I was initially interested in seeing whether the different 'passings' in the film (geographical, gendered, national, ideological) would also allow space for, and hint at more fluid configurations of gender, sexuality and national belonging. However, while Go West might be deemed transgressive and even bold for its focus on a same-sex, ethnically mixed couple in wartime Bosnia and Herzegovina, in my analysis I want to point out that the film's portrayal of gender and sexuality remains quite limited in its scope. Moreover, I argue that the film's stark division between a 'good' and 'bad' Europe reproduces some long-held beliefs about a progressive Europe (i.e. the West) and a backwards, Orientalized

34 It is popularly believed that the disintegration of Yugoslavia occurred as a result of inter-ethnic hatreds that spanned centuries before they would result in an explosive confrontation in I992. However, as Natasja Vojvodić argues in 'Gender Analysis in Ethnic Conflict: Causes \& Consequences in the Case of Yugoslavia,' the actual origins of Yugoslavia's breakup are to be found in the failure of socialist modernization processes which were marked by the death of Josip Broz Tito, former president of the socialist republic, in I980. Moreover, as Vojvodić shows (201 2, 3), the territory of Yugoslavia had historically been an intersection of many different ethnicities, and after its fall all of the resultant nation states struggled to acquire national identities that would be clearly enough distinct from their shared Yugoslav history. Today, from the seven countries that make up former Yugoslavian republics, only Slovenia and Croatia are members of the European Union. Croatia's membership was granted very recently, on July Ist 20I3, whereas Slovenia joined in 2004 . 
Europe, that always lags behind. It is my claim that the abundant emphasis on the irreconcilable division between East and West also results in a constricting and normative portrayal of gender and sexuality in the context of the former Yugoslavia.

My critical intervention in this article consists in making this particular narrative 'unstuck'. By pointing out the exclusions and stereotypical representations incorporated in the film's narrative, I want to argue that Go West's is a 'single story', which, in Chimamanda Ngozi Adichie's words 'creates stereotypes.... and the problem with stereotypes is not that they are untrue, but that they are incomplete' (Adichie 2009). The danger of this particular story is that it is presented as finite (as the imperative in the title suggests), complete and absolute, when no story ever is. It might obscure other possible stories that do not follow the same trajectories. Following Gayatri Spivak, what I am interested in is seeing to what extent the film's participation in already dominant normative narratives forecloses the possibility of movement, or alternative configurations to emerge. I am therefore less interested in whether a representation is 'good' or 'bad', but am rather 'looking for the mark of vulnerability which makes a great text not an authority generating a perfect narrative, but our own companion, as it were, so we can share our own vulnerabilities with those texts and move' (Spivak I990, 27). Movement is precisely the thing that is forestalled in Go West, while the its main narrative is presented as exemplary, since it features an ethnically mixed homosexual couple in wartime Bosnia. I am interested in seeing to what extent even a narrative such as this one, created with the aim to counter certain normative ideologies (presumably homophobia and xenophobia) does not manage to do so without reproducing other harmful ideological constructs (misogyny and the idea of irreconcilable differences between East and West Europe).

In my analysis of a post-socialist narrative that I am choosing to approach through a postcolonial lens, I am adopting David Chioni Moore's argument, which says that many (if not all) cultural situations nowadays bear the so-called postcolonial stamp, meaning that they all stand in some relation to postcoloniality (Moore 200I, I I2). Applying 
a postcolonial lens in studying a postsocialist narrative, such as the one found in the film Go West, might therefore be helpful in locating and addressing specific questions of power inequality, representational practices and the politics of belonging. Adopting this approach means that it is less important 'what a film is thematically about and more about how it engages with history, subjectivity, epistemology, and the political ramifications of all of these' (Ponzanesi and Waller 20II, I6).

\section{Synopsis}

The narrative opens in Sarajevo, Bosnia's capital, where Kenan, a young cellist and a Muslim confronts his lover Milan in a dark alley as they argue over the best choice of action to take now war has broken out. Milan thinks it is imperative that they flee the country, as they are not only a same-sex couple, but also an ethnically mixed one. However, Kenan is worried that he will be exposed as a Muslim, and throughout the film he frequently alludes to the fact that he is circumcised as being the thing that will give him away. ${ }^{35}$ As the situation in Bosnia worsens, the two leave for Milan's hometown village in Eastern Bosnia where they will wait until their travel documents are ready. In an act of desperation, Milan disguises Kenan as a woman and presents him to his father, friends and acquaintances as 'Milena,' his future bride. If the first section of the film was overwhelmingly bleak, it takes on a decidedly more bizarre tone almost until the very end, as the horrors of war are interspersed with eclectic and over-the-top scenes of village life in rural Bosnia. One particularly humorous segment of the film, evocative of the style of Emir Kusturica (Moss 20I2, 36r) is Milan and Milena's

35 Of course, Kenan's anxiety is doubled by the fact that he can be exposed as a Muslim in Serb territory and as a homosexual. In his analysis of Go West, Kevin Moss points to a trend in films from the former Yugoslavia of the early $2000 \mathrm{~s}$ that have a 'gay' thematic: all of them use the figure of the homosexual/lesbian as a metaphor for pointing to certain tensions that the filmmakers actually wish to address: issues of national belonging and ethnicity (Moss 201 2, 352). 
wedding, orchestrated by Milan's jubilant father Ljubo, who cannot contain his joy over his only son having finally settled down and decides to throw the 'happy' couple a surprise wedding.

As Milan is called up to join the army and is frequently away, a desperate Kenan befriends the social outcast and local witch Ranka, who upon discovering Kenan's true identity initiates and rather forces a sexual relationship to develop between the two of them. Realizing that Kenan will never love her as he does Milan, Ranka is shown performing a dark ritual at the local cemetery. The following day, Kenan and Milan's father receive the news that Milan has died in battle. Ranka, initially hopeful, realizes that even with Milan gone Kenan will never love her. She 'outs' Kenan in front of Milan's father, who, perhaps quite unexpectedly, does not turn on Kenan, but in his rage and grief kills Ranka for trying to disrespect his late son. He arranges for Kenan to escape Bosnia, tells him to 'go west,' after which he kills himself. In the closing scene, Kenan is shown giving an interview to a French journalist about his journey from East to West. He has lost his lover, his parents, his home and all his possessions, but he still has his music, which he demonstrates by playing an invisible cello, which the journalist professes being unable to hear.

\section{Key Intersecting Configurations}

The film starts with a documentary-like fragment in which Kenan's voiceover is heard. Throughout the film, Kenan will narrate periodically. In the opening scene of Go West, he tells the audience that the warring peoples of the former Yugoslavia may hate each other based on their different ethnicities and national ideologies, but they are all 'united' in their common hate for homosexuals: 'But this [mutual hatred among Catholic Croats, Orthodox Serbs, and Bosnian Muslims] will stop one day. They will lay down the guns and forget about the massacres. But they will continue to hate homosexuals as before. In the Balkans it's easier to bear if someone in the family is a murderer rather than a faggot.' 
A loaded statement, the quote is crucial for my analysis because it combines several key factors that converge in the film and that I want to address in this article, namely: sexuality, gender, ethnicity and nationality. I believe that it is imperative that these themes are not explored separately but in an intersectional manner. Intersectionality, as coined by Kimberle Crenshaw (1989, I39- I40), involves an analysis that is sensitive to the simultaneous imbrication of different axes of power in a given situation, based on overlapping social/political categories. Crenshaw has been vocal about the importance of intersectional thinking in feminist politics, as a lack thereof signifies a reproduction of a different type of normative discourse towards a group not taken into account by the oppositional voice..$^{36}$ An intersectional approach allows me to argue that constraints placed upon one identity category within Go West's narrative directly influence the scope of other (im)possible configurations. In other words, my claim is that Go West's lack of intersectional thinking means that for certain configurations to be given a 'human face' (homosexuality), others have to be caricatured (women/femaleness) - to the detriment of all.

To accompany this analysis, I will be looking at how movement is configured in the film's narrative - not just 'literal' movement that happens when one travels from one geographical location to the other (from East to West for instance), but also movement in a more metaphorical/symbolic sense. Therefore, transitions between different identity markers will be considered movement as well, as Kenan in the film 'moves' or transitions between different categories: male and female, Muslim and Serb, homosexual and heterosexual.

36 For instance, she has spoken about feminism's frequent reluctance to take into account questions of race and racial inequality, which ultimately leads to internal division and opposition within the movement: 'When feminism does not explicitly oppose racism, and when anti-racism does not incorporate opposition to patriarchy, race and gender politics often end up being antagonistic to each other and both interests lose' (Crenshaw I992, 405). 


\section{Transitory Moments}

Kenan's transformation into Milena does not only come with burdensome changes in his appearance (Kenan is often shown rushing to put his wig on or padding his bra whenever somebody is interrupting his time with Milan); as Milena he is quite literally relegated to the private sphere. He spends most of his time indoors, avoiding everyone except for Milan as much as possible, and experiencing a prominent loss of autonomy. Denise Riley talks about the dominant construct of separate spheres drawn along gender lines (Riley I988, 5 I), where women are relegated to the private sphere, while men are appointed to the cultural and political field. In the post-Yugoslav region, this framework largely gained prominence after the breakup of Yugoslavia as the rise of ethnonationalist ideologies in the new nation states carried with them the notion of 're-birthing' the nation, largely relegating women from the public to the private sphere. ${ }^{37}$ The character of Milena embodies this loss of autonomy.

The only female character in Go West who possesses some kind of agency is Ranka, who, likely because of her 'rebellious' nature and her status as the village witch, lives in almost complete isolation and is shown to be either feared or ridiculed by the locals. She is presented as an ominous, overtly sexual and potentially dangerous character who lives at the margins of society. Towards the film's end, she is shown performing a pagan ritual in the village cemetery, plotting Milan's demise. This framing of Ranka's character corresponds to the iconography of Lilith, the ultimate corruptible and corrupting female force, overtly sexual and morally unscrupulous. As the 'absolute protagonist of evil' (Martínez-Oña \& Muñoz-Muñoz 2015, 6r3), Ranka

37 The disintegration of Yugoslavia in the early I99os brought to the rise largely nationalistic political parties in the separate states. These conservative parties were motivated by religious and patriarchal ideologies that, among other things, propagated ideas of women's place being 'at home'. This ideological shift was reflected in a dramatic drop of female representatives in government functions, from $24 \%$ in 1986 to merely $3 \%$ in 1990 . Some feminists understood this shift as directly motivated by the desire to 'to regenerate nations through motherhood' (Bamburać, Jusić and Isanović 2006, 48). 
is represented through visual and narrative devices that associate her character with corruptible sensations and forces: sexuality, lust, greed and death, which she is made to pay with by her own dying. Both Ranka and Milena's personas become so overburdened with meaning that it forestalls their development as fleshed-out, three dimensional characters. In other words, the female character in Go West, in being 'still tied to her place as the bearer of meaning, not maker of meaning' (Mulvey 1975, I I2), is sacrificed for the sake of the narrative. This representational choice should be taken seriously because, as Anneke Smelik writes, 'cinema is a cultural practice where myths about women and femininity, and men and masculinity, in short, myths about sexual differences are produced, reproduced and represented' (1998, 7).

The absence of fleshed-out female characters is part of a conscious aesthetic choice by the filmmakers. Go West's producer, Samir Smajić, has said of the film that it is a classic love story, with one twist: 'We like to joke that it's a film about Romeo and Romeo — without the Juliet' (as quoted in Hawton 2005). This placating statement speaks of the desire to present a film with a very controversial subject matter - male homosexuality - in the most conventional, inoffensive way possible. Some agree that the creators were successful in their objective: one journalist even goes as far as saying that the film 'shows a very tender and human side of gay love, and there are no explicit scenes to upset those who are squeamish about the physical nature of homosexuality' (Brabant 2007). These sentiments urge the question of which audience was envisioned in making Go West, and it becomes readily apparent that a queer reception was not the most integral to the making of the film. As Kevin Moss observed, after having interviewed Imamović (who confessed not having done any research about LGBT culture in Sarajevo), the filmmakers interests were centered on 'conveying, particularly for a Western audience, the Bosnian experience during the war' $(2012,364)$. The relationship between Kenan and Milan is one characterized by distance (they share one moment of physical intimacy as Milan kisses Kenan in the beginning of the film, fleetingly, in a dark, shadowy alley) and isolation (Kenan and Milan's 
relationship is not contextualized into any kind of LGBT community in Sarajevo) (363). They appear as aberrations in the film's narrative, as bodies out of place. Tarik Filipović, who plays Milan, confirmed this uncomfortable, sterile portrayal of the two lovers by describing the film after its release as a 'film about homosexuals without faggotry' (Moss 2012, 363). The gay characters in Go West bear no semblance to actual queer/LGBT people in Bosnia, they 'are more simulacra and metaphor than real' (Moss 20I2, 366). This also becomes clear in the development of Ranka and Kenan's relationship: while Kenan develops a tentative friendship with Ranka, which eventually becomes sexual in nature, this connection is clearly one born out of desperation and isolation and does not further hint at a more nuanced or queer orientation. It is not a great surprise therefore that actual LGBT and queer persons from the former Yugoslavia had a negative response to the film, feeling mis- or unrepresented (Moss 2012, 366).

Further, Kenan's transition from a Muslim man to a Serb woman, in a Serb environment, does not give him much respite from his worries. His initial fear of being exposed as a Muslim, because he is circumcised, is replaced by a frantic fear of being exposed as a woman who is, in fact, a man, and a gay one at that. Ironically, his paranoia over 'having his pants pulled down and checked', persists even after his camouflage. Finally, the move from a cultured, even cosmopolitan Sarajevo at the beginning of the film to Milan's home village where most of the narrative takes place is almost like a step back in time, with a strong emphasis on, and exaggerated customs surrounding marriage, family and social life. Curiously, while Bosnia and Herzegovina is known for boasting amazing greenery and lush landscapes, particularly its rural areas, Milan's home village rather looks like what can best be described as a mountainous desert. It is not likely that anything fresh or new will grow from this dry land, the film seems to suggest. In any attempt at transition in the film, movement is completely forestalled. 


\section{Irreconcilable Differences between East And West}

How do these different 'passings' figure into the 'East vs. West' configuration in the film's narrative that I want to problematize? Throughout the film, different characters explicitly refer to the promise of a better life somewhere in the West, presumably Western Europe. Milan even explicitly states: 'Kenan, we will ruin our lives here. We have to go West.' At one point in the film, Milan explains to Kenan that they would be best off in the Netherlands, as the seasons there change four times per day, but the mood never does. After Milan's death, before he boards the train, Kenan is told, in short succession, by two characters to 'go West'. The satirical and farcical tone of the film in this final part reverts back to its somber and bleak, documentary-like tone.

Many scenes and situations I have illustrated so far, often played up for humorous effect in the film, are likely meant to be read as scathing social commentary on the homophobic and xenophobic attitudes present in Bosnian society. ${ }^{38}$ Nevertheless, due to the aforementioned absence of an intersectional framework, other depictions in the film easily correspond to stereotypical and dominant representations of the former Yugoslav states and their peoples as inherently socially, politically and culturally backwards with respect to the 'true' Europe. In her noted work Imagining the Balkans ([1997] 2009), Bulgarian scholar Maria Todorova speaks of the 'Balkanization' of this region in Europe ([1997] 2009, 3), constructed as the image against which the 'proper' Europe can differentiate itself. Although Todorova steadfastly avoids comparisons to Edward Said's Orientalism (1978), emphasizing that this is 'not merely a subspecies of orientalism' (Todorova 2009, 8), Imagining the Balkans is often understood as an adaptation of Orientalism onto the Balkan region, resulting in so-called 'Balkanism'. However, Todorova stresses that there are crucial differences between the two concepts, and that

38 The educational system in Bosnia and Herzegovina largely enforces negative views on homosexuality. Some school textbooks contain explicitly homophobic text, from which follows that intolerant attitudes towards difference and otherness in general are also being promoted (Schrag 2010, 58). 
Balkanism cannot merely be understood as 'orientalism in the Balkans':

As in the case of the Orient, the Balkans have served as a repository of negative characteristics against which a positive and self-congratulatory image of the 'European' and the 'West' has been constructed. With the reemergence of East and orientalism as independent semantic values, the Balkans are left in Europe's thrall, anticivilization, alter ego, the dark side within. (Todorova [1997] 2009, I89)

The most notable characteristic of Balkanism is that it constructs the Balkans as an ambiguous presence: neither wholly inside nor completely outside of Europe, the Balkans cannot be understood as the binary opposite of the West, as is the case with orientalism. If according to orientalism, the Orient is everything the Occident is not and vice versa, Balkanism is best understood as the West's rejected or failed Self (Trakilović 2015, 210) In other words, the distance between Self-Other is much more uncomfortably close in a Balkanist discourse. It seems to suggests that if the Balkans are barbaric and uncivilized, the 'proper' West is not that far behind. Perhaps this uncomfortable proximity explains the incessant desire in Go West to create some kind of clear duality by continually reproducing a discourse which is built upon irreconcilable differences between East and West. The stark, dry landscape, the petty village people with their crude traditions, these all seem to suggest that this is a region where movement halts: there is no transformation, no progression. Against this bleak image the vision of the West appears as a utopian place, where things evolve and people are evolved. Virtually all characters in Go West allude to this hopeless situation in the Balkans in some way or another. Most notably, this repetitive lamenting of the situation appears quite late in the film, during a scene in which Milan's father is addressing Kenan (who is still in his disguise as Milena). Talking about the terrible mess that the former Yugoslavia has found itself in during the war, he says: 'My child, you can buy everything here with money except happiness. There is no happiness here. Maybe there would be, if we drove away all the Muslims. And that handful of Croats and in the end us Serbs too. They should exile us all into hell. Then they should populate Bosnia with normal people that will be able to enjoy its beauty'. 
What is apparent in this speech is a ranking of the former Yugoslavia's peoples according to their respective 'redeeming qualities' thereby reproducing the discourse of 'nesting orientalisms'. This concept, credited to Milica Bakić-Hayden, is a phenomenon which is evident in the former Yugoslavia and its successor states where the designation of 'other' has been appropriated and manipulated by those who have themselves been designated as such in orientalist discourse' (Bakić-Hayden I995, 922). In other words - in an attempt to ward off orientalizing tendencies directed at themselves, certain nations and cultures in the Eastern Europe will resort to Orientalizing their neighbors by reproducing in discourse a sliding scale of inferiority according to which those who are considered to be more 'eastern' are therefore understood as being less developed culturally and politically (Bakić-Hayden r995, 918). The above film quote demonstrates nesting orientalism at work, by employing the characteristic 'tendency of each region to view the cultures and religions to its South and East as more conservative and primitive' (Bakić-Hayden \& Hayden I992, 4) In other words, this phenomenon manifests in certain cultures of the Balkans essentially Orientalizing their neighbors in order to establish their own distinct identities.

Milan's father's quote starts out as a case of nesting orientalisms (by ranking some of the ethnic groups of the former Yugoslavia from 'worst' to 'less bad'), it takes something of an unexpected turn by the end. It has been pointed out that nesting orientalisms manifest in a specific regions in Europe, in this case the Balkans, through the construction of an identity built on the orientalization of another nation or ethnic group that is 'lower', both geographically and economically. Therefore, what starts off as a case of nesting orientalisms in Milan's father's speech, as he lists those who should be eliminated from Yugoslav soil (presumably for being too primitive or too backwards- first the Muslims, then the Croats), finally transforms into a Balkanist discourse as he claims that even his own ethnic group should be eradicated. In other words, Ljubo, reproduces a discourse of the Balkans as irredeemable and barbaric, as he claims that even the Serbs (his own people) should be eliminated from Yugoslav soil. I have previously noted that Balkanism refers to 
an adaptation of Orientalism, where the Self-Other duality is replaced with a good Self and failed Self (Trakilović 2015, 2 Io). In Go West, the former Yugoslavia and its peoples are seen as a lost cause, an obsolete life form even that does not stand a chance of betterment. The only sensible solution, the film seems to suggest, would be to 'start over' and repopulate the region with so-called 'normal' people.

It might seem that this statement made by Milan's father contradicts Kenan's statement from the beginning of the film, in which he proclaimed that one day the peoples of the former Yugoslavia would lay down their weapons and stop hating each other. However, let us not forget that Kenan also emphatically stated that the people of ex-Yugoslavia would never stop hating homosexuals. In Go West's narrative, freedom for sexual minorities is something that will never be a reality in the Balkans, because of the innately barbaric nature of its peoples. Therefore, I place Kenan's argument is also in line with Milan's father's musings on the best course of action to take regarding the warring republics of the former Yugoslavia. Motivated by rage and grief, both characters are actually reproducing a stereotyped, Balkanist discourse about the bloodthirsty and irredeemable nature of the peoples of former Yugoslavia. In Imagining the Balkans, Maria Todorova notes that there is a trend of representing and reporting on the Balkans in general only in times of war and conflict; 'the rest of the time they are scornfully ignored' ([1997] 2009, I84). Go West, even while engaging with a very controversial subject matter with the aim of opening up a dialogue around it, seems to participate in this trend. By reproducing a clichéd, Balkanist discourse, whether ironically or unironically, the film also reproduces a very closed narrative. By showcasing the tragic story of two homosexual lovers in war-time Bosnia, the narrative concludes that people like them do not have a future on the territory of the former Yugoslavia and need to — there it is again — 'go west.' By stating, time and time again, that sexual minorities do not stand a chance at survival in the territory of the former Yugoslavia, Go West eradicates the lives and stories of those LGBT people who have and who continue to survive. Maria Todorova argues that there is a 'frozen vision' of this region in 
Europe that permeates Western consciousness, making it 'more than a stereotype':

It appears as the higher reality, the reflection of the phenomenal world, its essence and true nature, the 'noumenon' to the 'phenomenon', to use the Kantian distinction. None of the politicians, journalists, or writers who have specialized in passing strictures on the Balkans have ever made a claim for a philosophical basis of their argument, yet this is what they have achieved. The frozen image of the Balkans, set in its general parameters around World War I, has been reproduced almost without variation over the next decades and operates as a discourse. (Todorova [1997] 2009, I87 emphasis mine)

The issue with Go West is not that it reproduces a negative narrative, but rather a very static one that seamlessly fits into a Balkanist vision of the ex-Yugoslav region. Moreover, as Todorova (1997) points out, reproducing such a 'frozen vision' of the Balkan region is detrimental because it is not merely aesthetic, but an active reproduction of a harmful and often unchallenged discourse - and I understand discourse here in a Foucauldian fashion as a power-laden enterprise; an apparatus that determines what can and what cannot be said regarding a particular topic in any given situation, thereby informing the narrative(s) of truth about and in the world (Foucault 1980,194- I96). The fact that the public outrage about the film's supposed 'controversial' content died down upon the film's release is indicative of Imamović's desire not to stir the pot and produce a story in which homosexuality is a narrative device (i.e. not real) and simultaneously constructed as something that can only exist outside of the territory of the former Yugoslavia. Returning to the notion of movement I had introduced previously, it is apparent that the film's narrative seems to suggest that movement is possible elsewhere, as the region of the former Yugoslavia will always remain at a standstill in some sense, and will therefore always lag behind another, supposedly more advanced Europe which, as I have argued, is invoked through a 
simultaneously present discourse of Balkanism (portraying the Balkans as backwards in contrast to the 'real' Europe) and nesting orientalisms (Orientalizing one's neighbors according to a sliding scale of inferiority). Going West in this context does not only represent a yearning for a better life, removed from war, conflict, as I claimed at the beginning of my paper, but also an inevitability for any kind of life, and it is through an emphasis on this one-directional movement that the unchallenged and unbalanced division between Europe's East and West is maintained and enforced.

\section{Conclusion}

Go West certainly made waves when it first appeared in Bosnian cinemas in 2005 . The film had gained a status of notoriety even months before its release, as its subject matter (homosexual love) did not sit well with a very large number of the Bosnian population. The fact that two prominent media figures played a same-sex couple in a film about war-time Bosnia and Herzegovina sparked religious and nationalistic outcry (Soares 2005). The impression may be conveyed that the film was bold in the choice of its subject matter (portraying a relationship between two gay men), and that it addressed a matter that is rarely spoken about publicly (homosexuality). While this is certainly the case, ultimately, its execution fails to step outside of some very normative frameworks, which leads me to conclude that movement is severely restricted - in virtually any sense - in Go West's narrative. Ironically, although it contains some deeply satirical elements, Go West nevertheless presents an unsubverted image of the former Yugoslavia as incompatible with the very possibility of homosexuality, which is a notion that the detractors of the film would happily stand behind. In Imagined Bodies, Imagined Communities, Krista Scott argues that 'if we accept Benedict Anderson's proposal that the nation is an 'imagined community", and that '[c]ommunities are to be distinguished... by the style in which they are imagined', then it stands to reason that how we imagine 
our community fundamentally influences how we experience it' (I999). Imagining differently, therefore, becomes a crucial act of resistance to oppressive ideologies. It is precisely the option of alternative configurations that the film seems to rule out, as it reproduces some deeply rooted and even clichéd ideas about Europe's East vs. its West and emphasizes this divide. Such simplified rhetoric in my opinion serves to enforce borders rather than question them - not just literal ones, and not merely between East and West, but also around other configurations (gender, sexuality, nationality/ethnicity). If Europe's East and in particular the Balkans are assumed to be forever backward and forever behind the West, then it is implied that sexual liberation and gender equality are also to be found elsewhere. The foreclosing that takes place in Go West is absolute, allowing only one-directional (westward) movement. In its attempt to be critical satirical of certain practices and beliefs, the film ultimately erects invisible but absolute borders, or rather 'formidable reducers of complexity', to quote Étienne Balibar (2002, 76), between the West and its Wild East. 


\section{Works Cited}

- Adichie, Chimamanda Ngozi. 2009. The Danger of a Single Story. TED talk. https://www.ted.com/talks/ chimamanda_adichie_the_danger_of_a_single_story?

- Bakić-Hayden, Milica. I995. "Nesting Orientalisms: The Case of Former Yugoslavia.” Slavic Review 54, no. 4: 917-31.

- Bakić-Hayden, Milica and Robert Hayden. I992. "Orientalist Variations on the Theme 'Balkans': Symbolic Geography in Recent Yugoslav Cultural Politics." Slavic Review 5 I/I: I- I5.

- Balibar, Étienne. 2002. "What is a Border?” In: Politics and the Other Scene, 75-86. London: Verso.

- Bamburać, Nirman Moranjak, Tarik Jusić and Adla Isanović, eds. 2006. Stereotyping: Representation of Women in Print Media in South East Europe. Sarajevo: Mediacentar.

- Brabant, Malcolm. 2007. "Go West - A Story about Romeo and Romeo.” Qantara, September 7. https://en.qantara.de/content/ controversy-over-bosnian-film-go-west-a-story-about-romeo-and-romeo

- Crenshaw, Kimberlé. 1989. "Demarginalizing the Intersection of Race and Sex: A Black Feminist Critique of Antidiscrimination doctrine, Feminist Theory and Antiracist Politics." University of Chicago Legal Forum i: I39- I67.

- Crenshaw, Kimberlé. I992. "Whose Story Is It, Anyway? Feminist and Antiracist Appropriations of Anita Hill.” In: Race-ing Justice, En-gendering Power, edited by Toni Morrison: 402-40. Pantheon.

- Foucault, Michel. 1980. Power/Knowledge: Selected Interviews and Other Writings, I972 - 1977, edited by Colin Gordon. New York: Pantheon.

- Hawton, Nick. 2005. "Gay war film stirs Bosnian anger." BBC News, March 2I. http://news.bbc.co.uk/2/hi/entertainment/4368077.stm

- Imamović, Ahmed, dir. 2005. "Go West." Comprex. Film.

- Moore, David Chioni. 20or. "Is the Post- in Postcolonial the Post- in PostSoviet? Toward a Global Postcolonial Critique.” In: PMLA, vol. I r6, no. I, Special Topic: Globalizing Literary Studies, Jan. 2 I I - 228.

- Martínez-Oña, MM \& Muñoz-Muñoz, AM. 2015. "An Iconographic analysis of the myth of Lilith in advertising." Revista Latina de Comunicación Social, 70: 61 I -626 .

- Moss, Kevin. 201 2. "Queering Ethnicity in the First Gay Films from ExYugoslavia." Feminist Media Studies, I 2/3, 352-370.

- Mulvey, Laura. I975. "Visual Pleasure and Narrative Cinema.” In: Screen I6/3.

- Ponzanesi, Sandra and Waller, Margueritte. 2or r. "Introduction.” In: Postcolonial Cinema Studies, edited by Sandra Ponzanesi and Marguerite Waller, I - i6. Abingdon: Routledge. 
- Riley, Denise. I988. "The Social', 'Woman', and Sociological Feminism." In: Am I that Name?: Feminism and the Category of "Women" in History, 44-66. London: The Macmillan Press Ltd.

- Said, Edward W. 1978. Orientalism. New York: Random House.

- Scott, Krista. I999. "Imagined Bodies, Imagined Communities. Feminism, Nationalism, and Body Metaphors.” In: The Feminist eZine.

- Schrag, Sarah. 2oro. "We Can No Longer Declare Ourselves a Multicultural City Until We Start Reacting to Things Like This: Contextualizing the Violence at the 2008 Queer Sarajevo Festival.” In: Independent Study Project (ISP) Collection. Paper 844. http://digitalcollections.sit.edu/ isp_collection $/ 844$

- Smelik, Anneke, M. 1998. And The Mirror Cracked: Feminist Cinema and Film Theory. St. Martin's Press, New York.

— Soares, Andre. 2005. "'Go West': Gay Film Spark Religious-Nationalistic Outrage.” Alt Film Guide, 30 March. http://www.altfg.com/film/ bosnian-gay-movie-go-west-sparks-outrage/

- Spivak, Gayatri Chakravorty. I990. "The Post-modern Condition: The End of Politics? Interview with Geoffrey Hawthorn, Ron Aronson, and John Dunn.” In: The Post-Colonial Critic. Interviews, Strategies, Dialogues, edited by Sarah Harasym. I7-34. London/New York: Routledge.

- Stovel, Laura. 2000. "Confronting Ethnic Chauvinism in a Post-War Environment: NGOs and Peace Education in Bosnia.” Bradford, Centre for Conflict Resolution, Department of Peace Studies, University of Bradford. CCR Working Papers: No. 7.

- Todorova, Maria. (I997) 2009. Imagining the Balkans. New York: Oxford University Press.

- Trakilović, Milica. 2015. “'The Other Within”: Challenging Borders from the

- European Periphery.” In: Postcolonial Transitions in Europe. Contexts, Practices and Politics. Edited by Sandra Ponzanesi and Gianmaria Colpani, 209-228. London: Rowman \& Littlefield International.

- Vojvodić, Natasja. 201 2. "Gender Analysis in Ethnic Conflict: Causes \&

- Consequences in the Case of Yugoslavia.” University College London: School of Slavonic and Eastern European Studies. 


\section{ARTICLE 5 \\ "The Other Within": Challenging Borders from the European Periphery}

Published the edited volume Postcolonial Transitions in Europe:

Contexts, Practices and Politics (eds. Ponzanesi \& Colpani).

Rowman \& Littlefield International, 2016.

\section{Abstract}

While postcolonial studies have stepped into dialogue with postsocialist frameworks, there remains a need for critical and creative tools from the postsocialist arena with which to enrich postcolonial theory. The Balkans represent an ambiguous entity in Europe; geographically inside but ideologically outside, this region can be considered Europe's constitutive other, or the "other within." Not only does art from the former Yugoslavia frequently play with this indeterminate position to produce works that challenge the politics and ideology behind Fortress Europe in terms of the artistic content that they produce, but, as I claim in this chapter, it is the Balkans' very status of "in-betweenness" that gives artworks produced in this region their transgressive force. To develop this argument, I situate my analysis largely in relation to Bulgarian scholar Maria Todorova's concept of "Balkanism." According to Todorova, Balkanism does not operate according to a binary logic characteristic of much colonial and orientalist discourse; there is no absolute dichotomy here. Instead of operating according to a Self-Other distinction, Balkanism rather speaks of a failed Self. This inherent ambiguity can be used productively in the creation of art as a "border crossing practice," which I showcase through three select examples of ex-Yugoslav visual art.

Keywords: art; postcolonial; postsocialist; Europe; Balkanism; gender 


\section{Introduction}

In recent decades, scholars and critical thinkers have lamented the fact that postcolonial studies have not stepped into close(r) dialogue with Europe's postsocialist political and cultural frameworks. As David Chioni Moore (200I, II2) points out, the postcolonial today can roughly encompass virtually all groups of people, for "all groups on this earth...have come from somewhere else." Nevertheless, Moore observes that a "colonizing standard" (I2O) has been dominating the sphere of postcolonial studies, according to which the former Socialist Bloc is not seen as properly postcolonial for two distinct reasons: "the lack of ocean between Russia and what it colonized, and...the way... Russia has long been typed (and has typed itself) as neither East nor West" ( I I g). Postcolonial theory's reluctance to engage with postsocialist realities had for some time signaled a certain blind spot that regrettably left a vast geopolitical area underexplored and unexamined with the tools of postcolonial theory. However, this lack of dialogue has not been stagnant; indeed, as Anikó Imre (2014) points out, it is nowadays not exactly necessary to argue that the postsocialist region is postcolonial, for many thinkers and critics have already made this point. What still remains to be done, however, is to broaden the scope of postcolonial theory itself with tools emerging from postsocialist realities: "The spatial expansion of postcolonial discourse to Europe's own backyard needs to be matched by an expansion of research methods and objects" (I I 4). Therefore, my primary aim, in this chapter, is not to argue for the already established productive merger between postcolonialism and postsocialism. Rather, I aim to theorize the specificity of post-Yugoslav visual art as a critical tool for analysis capable of expanding the European postcolonial framework at large. I argue that art from the former Yugoslavia frequently challenges (directly or indirectly) the idea of a unified Europe, questioning borders and promoting transitions through a close engagement with, rather than a distancing from, harmful discourses and representations of the Balkan region proceeding from a West European standpoint. 
I side with Rosi Braidotti (1996) when she observes that "the creative spirits have a head start over the masters of metadiscourse, even and especially of deconstructive meta-discourse." Art, therefore, is in a fashion "ahead" of theory in conceptualizing and producing work that is critically and creatively engaged with current sociopolitical realities that frame Europe, and beyond. If postcolonial theory can benefit from fresh insights gleaned from the postsocialist context, critical discourses could benefit from the provocative and often unpredictable ways in which art engages with questions of identity and belonging. Much art production from the former Yugoslavia finds itself at the nexus of various intersections (e.g., postcolonial/postsocialist, East/ West, aesthetics/politics), and therefore presents a unique intervention into both critical discourse and postcolonial theory, expanding the geographical and historical reach of the latter as well as the range of objects and strategies of intervention of the former. By extrapolating some of the central points from Maria Todorova's seminal work Imagining the Balkans ([1997] 2009) on what constitutes a discourse of Balkanism, ex-Yugoslav art is shown to be valuable to European postcolonial and critical theories precisely because, as it often engages with themes regarding Yugoslavia's disintegration, it also challenges, implicitly or explicitly, the presuppositions upon which the idea of a unified and just Europe is built. The concept of Balkanism is crucial to apprehend the subversive potential inscribed in this type of art practice, as the Self-Other dichotomy characteristic of traditional colonialist and orientalist discourse is overturned into a more challenging configuration that speaks, instead, of the 'good' and 'bad' sides of an inherently split Self, or a failed Self, thereby complicating a number of clear-cut binary configurations that Europe today rests on - 'East' and 'West,' center and periphery, native and migrant. Since Todorova's concept of Balkanism speaks of the Balkans as the 'dark side within Europe,' ex-Yugoslav art is significant because, in addressing the problematic of the Balkans, it is always already addressing, through a politics of parody, mimetic performance, or a combination of both, the problematic of Europe as well. 
In exploring art as a subversive practice, my aim is to theorize the artworks themselves, not as aesthetic objects to be consumed and interpreted, but as agential phenomena that possess transformative potential. Considering artworks by ex-Yugoslav artists in this manner, it becomes possible to notice, beyond or besides their aesthetic potential, also their role as agents capable of articulating complex issues of political and social significance. Engaging with art, then, becomes an activity or, as Tihana Bertek $(2013,32)$ puts it, a "state of encounters." In other words, my argument takes as its point of departure the acknowledgment that art does not constitute a distinct sphere from ethics and politics (Papenburg and Zarzycka 20I3, I), and thus needs to be further recognized and theorized as such.

\section{Balkanism and the Art of Disidentification}

Artworks by ex-Yugoslav artists, always already politically inclined, provide fruitful ground for the exploration of the complicities that come from the ideological division between Europe's West and East. According to Todorova ([I997] 2009, I I - I2), the East-West distinction has been "an opposition as old as written history" but has acquired a specific meaning for the European context since the time of the Enlightenment, when the element of time was introduced to signify the (industrially) prosperous West and the underdeveloped East. In her contribution to this volume, Rasa Navickaite also speaks of a "temporal framing" of the East-West division in Europe in the scholarship on postsocialist sexuality, according to which the East is understood as always already lagging behind the West in terms of sexual liberation and social progress. Moreover, if the East is to be emancipated or liberated, this transition will presumably happen according to a Western model (since it is assumed that emancipation and liberation have already occurred there).

The temporal lag between East and West Europe works according to a binary logic, which the first artwork discussed in this 
chapter skillfully overturns. Consider the following piece by Serbian artist Slobodan Stošić, soberly titled "Taking over the Sea" Proposal for land art project' (2OI2). (See FIGURE I) As the name indicates, this work functions as a sketch for a geopolitical land art project; but it also proposes itself as an ideological solution to the 'problem of the Balkans,' which represent the irredeemable part of Europe. As a solution, the artist presents a geographical map on which the space of the former Yugoslavia has been completely eroded and overrun with water, as the Adriatic Sea has expanded onto what was previously land. In a blog entry introducing his work, the artist explains his reasoning:

This sketch for geopolitical land art project is also a proposal which offers solution for what is labeled as Balkan mentality (mostly concerning ex- Yugoslavian countries) which is riven by ethnic tribalism, nationalist feeling, authoritarian regime, divided borders, corruption, inequality and many other parameters of social structure. With no end in this sight, covering this land with sea seems like the only strategy. Past and present are seen from imaginary conception and presented as a historical example. In the end there would be nothing left except the sea, a metaphysical dream, beyond humanity. (Stošić 2OI 2)

Stošić makes use of a jarring rhetoric in his proposal; although highly ironic, it nevertheless contains an underlying sense of urgency. $\mathrm{He}$ is provocatively proposing that the area of the former Yugoslavia be leveled with the ground and drowned with water, suggesting that only through such a drastic measure would this forever-turbulent region finally enjoy a modicum of peace.

Describing the region as beyond salvation due to the irredeemable, savage nature of its peoples, Stošić purposefully takes part in in a long-standing representational tradition depicting the Balkan region not merely lagging behind the 'true' Europe, but also as inherently violent, barbaric, and bloodthirsty. In Imagining the Balkans, Todorova 


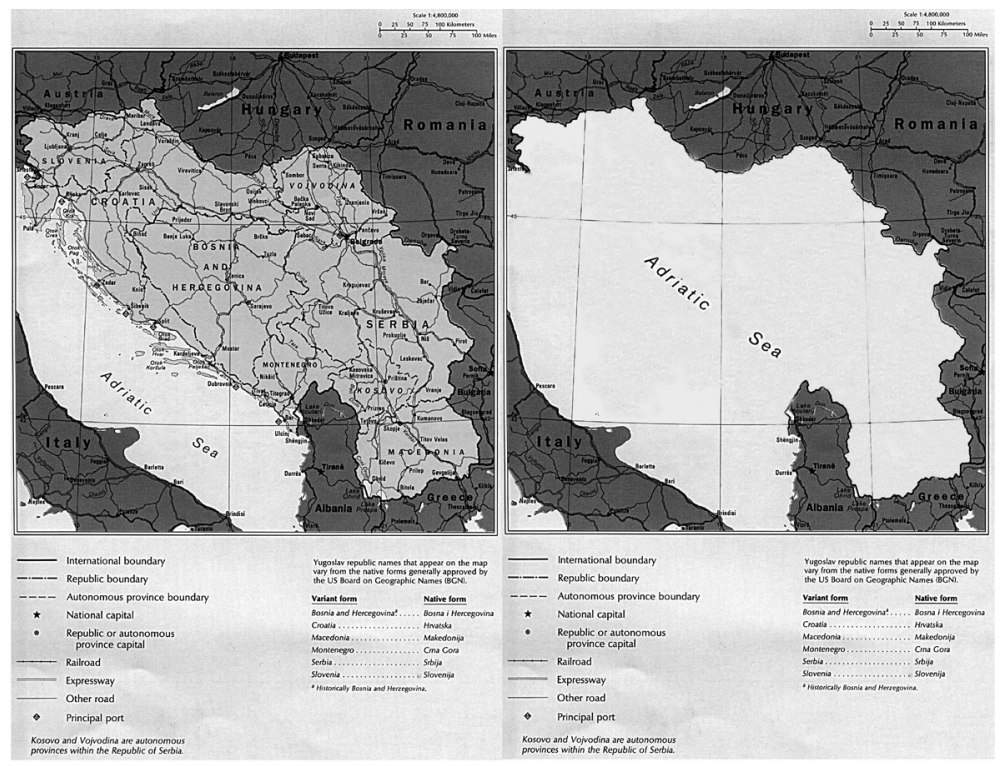

Figure I: Slobodan Stošić, “Taking Over the Sea”-

Proposal for Land Art Project,' 2012.

speaks of the "Balkanization" of this region of Europe, in that it does not stand for the feminine and the feminized, the forbidden and the sensual, but rather for that which is not forbidden: the crude, the hypermasculine, the barbaric. There is nothing mysterious about the Balkans. For Todorova, Balkanism operates according to an image against which the 'proper' Europe can differentiate itself. A clear play on Edward Said's (1978) concept of "orientalism," Todorova nevertheless stresses that the Balkanist discourse is highly specific and significantly different from the orientalist one. She stresses that Balkanism should not be understood simply as 'Orientalism in the Balkans,' as there are some crucial differences between the two concepts:

As in the case of the Orient, the Balkans have served as a repository of negative characteristics against which a positive 
and self-congratulatory image of the "European" and the "West" has been constructed. With the reemergence of East and orientalism as independent semantic values, the Balkans are left in Europe's thrall, anticivilization, alter ego, the dark side within. (Todorova [I997] 2009, I89)

Balkanism, therefore, does not inscribe the clear-cut Self-Other dichotomy characteristic of orientalism, but rather denotes "the other within." Perhaps the discourse could also be understood as producing the image of a failed Self. In this manner, Balkanism complicates binary oppositions that much colonial discourse is built on, and also departs from orientalism, which opposes the rational, civilized West to the feminine, sensual, and uncivilized Orient. ${ }^{39}$ In his land art project, Stošić makes use of a very similar representational frame - due to its bloody history, the Yugoslav region has been too corrupted to ever come out unscathed, hence the proposal to cover it with water. Interestingly, Stošićs work also functions according to the structure of what Milica Bakić-Hayden (1995) has termed "nesting orientalisms," ${ }^{\circ}$ a phenomenon whose legacy, in the East European region at large, reproduces "the discourse of Central Europe as a redeemable Eastern Europe and the Balkans as an irredeemable, extreme, and problematic Eastern Europe” (Kovačević, quoted in Veličković 20I 2, I66). This

39 The belief in the supposedly barbaric and bloodthirsty nature of the Balkans has been significantly amplified with the breakup of Yugoslavia in the early I990s. Western media in particular was quick to interpret the situation in sensationalist terms that correspond to the Balkanist discourse Todorova describes. An overwhelming emphasis was placed on the situation in Bosnia and Herzegovina, which was most dire.

Another adaptation of Said's "orientalism," the concept of "nesting orientalisms" refers to a tendency the Central-East European region, to see the traditions, cultural practices, and national identities of one's neighboring countries further East as (more) inferior, backwards, and uncivilized than oneself. In other words, this phenomenon manifests in certain cultures essentially orientalizing their neighbors in an attempt to establish their own distinct national and cultural identities. This particular configuration is useful in tracing the different types of nationalisms that have characterized the Balkan region. 
becomes apparent when we notice that, in Stošićs project, only the territory of the former Yugoslavia is erased, while none of the other (neighboring) countries, with their own specific histories of war and conquest, are deemed beyond repair. As the Adriatic Sea takes on an unexpected form expanding onto the area of the former Yugoslavia, it becomes a warning of sorts for the rest of Europe, the unnatural expansion admonishing: "watch out, you could be next."

Stošić presents the ex-Yugoslav region as despicably barbaric and backward according to a typically Balkanist discourse. However, it is important to insist that Todorova's conception of Balkanism stipulates that the Balkans do not stand for Europe's Other, but rather Europe's failed Self, the "other within." Therefore, the drowning of Yugoslavia has direct repercussions on the rest of Europe, as it signals an erosion of borders from the inside. The failure of Yugoslavia becomes a failure of Europe, and Stošićs piece comes to demand a (re)awakening of responsibility, not just for a widely misunderstood and misrepresented region, but also for the very processes of topographic classification according to which the Balkans become Europe's 'Wild West' in the first place (or, in fact, its Wild East). What seems to be a clear-cut solution to 'Europe's problem' - if all else fails, the artist ironically suggests, simply remove the bothersome part - in fact becomes an ominous foreshadowing for the Europe that has not been drowned yet. The temporal lag characteristic of the intra-European binary is overturned into a scenario where the East will not inherit the West's emancipation (at least the region that was the former Yugoslavia), but the West itself is in danger, instead, of following the East's 'self-destructive' path.

With this work, the artist seeks to disidentify from his ancestry and heritage in the most absolute way. However, this disidentification is in fact tactical and performative, as it serves to question the dominant nationalist ideological apparatus that has characterized the post-war Yugoslav space. According to José Esteban Muñoz:

Disidentification resists the interpellating call of ideology that fixes a subject within the state power apparatus. It is 
a reformatting of self within the social, a third term that resists the binary of identification and counteridentification. Counteridentification often, through the very rutinized workings of its denouncement of dominant discourse, reinstates the same discourse. (Muñoz I999, 83)

By denouncing the very possibility of national belonging in the Balkans (because the former Yugoslavia is, in this piece, obliterated altogether), the artist performs a radical gesture of disidentification, for he not only comments on a dire, isolated sociopolitical situation, but signifies a fundamental rejection of straightforward dualisms according to which national identities are routinely formed and sustained. The explicit critique of the Balkans, through the very discourse of Balkanism that disavows a clear-cut Self-Other binary, cannot but entail a critique of Europe's own implication in the fatalistic, sensationalist, and destructive discourse that has been crafted around the region of the former Yugoslavia. Employing a Balkanist rhetoric in his work, Stošić is able to critique the post-Yugoslav descent into ethnic rivalry and nationalism, but also, and at the same time, the foundations upon which European identity is built. The artist performs a double move in this work; he both employs and disidentifies from a Balkanist narrative. In doing so, he expands a critique of the Balkans to include a critique of Europe itself, as the ideological nature of the Balkanist discourse that has been directed from West Europe towards the Balkans is exposed. Crucially, the artist does not adopt a West European gaze either, but rather, by disidentifying with the Balkans and making use of the Balkanist frame to that end, he promotes an act of radical disidentification that questions the very idea of territorial belonging.

\section{Balkanism as Mimetic Performance}

Apart from complicating the Self-Other distinction through the figure of the failed Self, Balkanism is further characterized by a habit of 
representing and reporting on the Balkans generally only in times of war and conflict; "the rest of the time they are scornfully ignored" (Todorova [1997] 2009, I84). Accompanying this type of sensationalist attention to the region in times of conflict is also a similar, perhaps more dangerous discourse about the inevitable influx of migrants from the war-torn Balkan region following the collapse of Yugoslavia. The sensationalist reporting on the I990s wars in the Balkans created an image that was later recuperated, with the accession of some ex-Yugoslav countries to the European Union (EU), in paranoid discourses over intra-European mobility. Vedrana Veličković (2012, I7I) observes a trend in Britain, indicative of a larger tendency in West Europe, according to which migration from East Europe following the acquisition of EU membership by former communist/socialist states is routinely met with anxieties regarding identity, belonging, movement, and nationality. Newspapers are now scattered with articles fearfully announcing the influx of hordes of migrants. Veličković aptly notes that, in situations like these, the "right to freedom of movement guaranteed by EU membership is...quickly brushed aside" (I7I).

These observations shed light on the fact that, even within Europe, freedom of movement is reserved only for certain subjects, bodies, and citizenships; and that, as Anikó Imre suggests in her contribution to this volume, South and East European peripheries are always only contingently included in the idea of Europe and its political project. The EU's migration policy perhaps most clearly brings to light the inequalities between Europe's East and West. Movement is allowed for some bodies while restricted for others. Citizens of the former Yugoslavia know this all too well, since the collapse of the former socialist republic in the early I 990 s resulted in the imposition of strict visa regimes in the newly formed nation-states. In fact, for citizens of Bosnia and Herzegovina it was not until December I5, 20I0 that visa restrictions were lifted and 'free' travel in Europe became possible.

In 2003, when the visa regime was still firmly in place in Bosnia and Herzegovina, artist Šejla Kamerić created what would be her most noted work, entitled "Bosnian Girl." (See Figure 2) The work consists 
of a black and white photograph of a slim young woman staring seriously at the camera. Over her image appears the text: "No teeth...? A mustache...? Smel like shit...? Bosnian Girl!" The juxtaposition between the pristine image of the serious woman and the degrading text creates an arresting vision. The woman in the photograph is not a nameless person, but the artist herself. Kamerićs source material was a text that was originally written on a barrack in the Bosnian village Potočari, near Srebrenica, by an unidentified Dutch soldier (ironically, the Dutch military was appointed to this region during the Bosnian war to offer protection to Bosnian citizens from Serb military forces). The soldier's statement is represented as all encompassing: through a typically Balkanist rhetoric (invoking masculinization and primitivism), it lists the supposed characteristics of a 'Bosnian girl,' thereby locating her by tying her to this image. Kamerićs work shows how women's bodies come to be fixed, not just by national ideologies, but also by the cultural imaginaries of other (European) communities, and how war becomes a marker of the female body as territory.

In times of conflict and times of war, women's bodies typically become overburdened with meaning as they come to stand for 'the nation.' Jan Jindy Pettman (1996) talks of a complex configuration in which women become the literal boundary keepers of national territories, their bodies marking the land that they represent. As national borders come to be monitored and 'protected,' women's agential possibilities dwindle as a consequence: "policing the boundaries too easily becomes the policing of women's bodies and movements" (37). From this logic follows that women belonging to the nation are in need of protection, while 'enemy' women may be invaded and conquered, and by extension, their nation as well. (Scott 1999). Julie Mostov (2000, 90) explains how, during the disintegration of Yugoslavia, the former socialist regime was replaced in the resulting nation-states by an ethnonational model that was accompanied by a severe reduction in the figurations of political subjectivity for women. The conditions under which, during this time, women were relegated to the status of 'nation-bearers' attest to the very limited and heavily polarized roles available for women in a dominant nationalist 


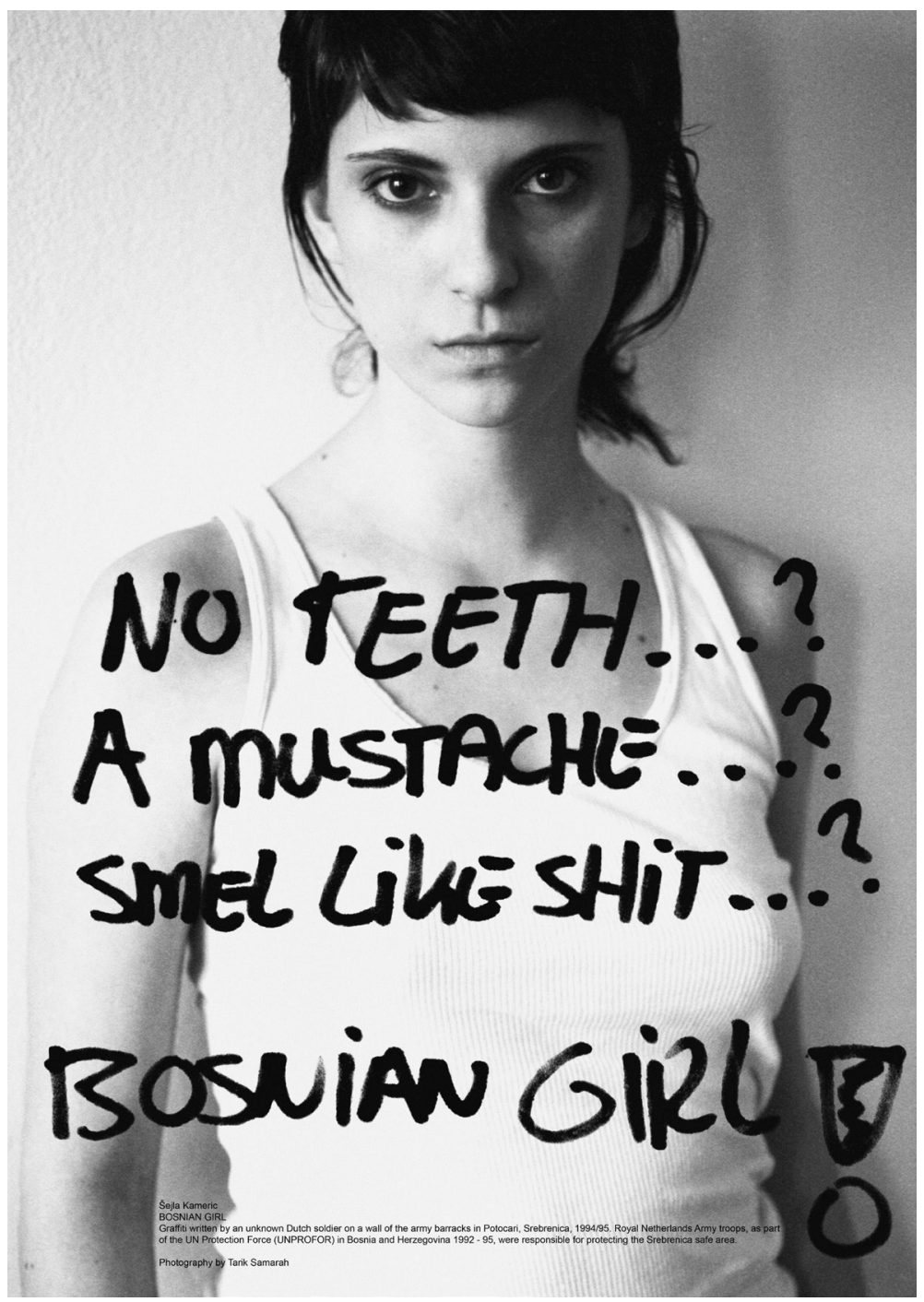

figure 2: Šejla Kamerić, 'Bosnian Girl,' 2003. 
discourse; either that of faithful mother/wife or that of traitor/Other. As this ideological positioning of the nation was built upon the notion of the patriarchal family, women were systematically excluded from a political discourse as they carried a symbolic, rather than agential role (Vojvodić 20I2, 4).

In "Bosnian Girl," the imagined body of a Bosnian woman also becomes overdetermined with metaphorical meaning as she is fixed in a certain time and place by the graffiti written by the unidentified soldier. Kamerićs positioning of the text over a photograph of herself, then, becomes a contestation of this reading, a destabilization of the words that were meant to leave marks on bodies. The artist's choice to superimpose the soldier's graffiti over an image of herself represents, also in this case, a direct engagement with a Balkanist discourse. However, this time the subversive potential is not to be found in an act of disidentification, but rather in a mimetic performance of a harmful stereotype.

According to Luce Irigaray $(1985,76)$, mimesis offers a special opportunity for women to take up a violent image, a stereotype born out of a phallocentric logic, and give it new meaning by embodying it differently from its intended purpose. What Kamerić achieves with the clean, polished image of herself is not simply a rebuking of the harmful, racist, and sexist text; she also relocates the image of the "Bosnian girl" to a position that the graffiti seemingly foreclosed. After all, the image of the artist, save for the violent graffiti, looks like a typically western advertising campaign: an attractive young girl with big dark eyes, slim physique, and a polished, clean look. By mimetically occupying the image of the 'Bosnian girl,' Kamerić moves her to alternative registers of signification, away from the graffiti left by the Dutch soldier that represents a god-trick, ${ }^{4 \mathrm{I}}$ a vision that comes from nowhere and whose disembodied nature is further emphasized, in this case, by the fact that the soldier was never identified.

On the other hand, Kamerić offers us an embodied, particular,

4I In her by now classic "Situated Knowledges: The Science Question in Feminism" (1988), Donna Haraway speaks of the 'god-trick' of vision, a disembodied act of seeing that disavows accountability. 
situated vision. Moreover, by virtue of her confrontational gaze, in "Bosnian Girl" she also locates the viewer and makes he or she accountable for their own practices of looking. If the body of the "Bosnian girl" is pinned by the gaze of the viewer, she scrutinizes the viewer in turn. Kamerić thus challenges the hierarchy between seer/seen and, therefore, the power of the soldier who left the violent words on the walls of a barrack. Her self-portrait allows the gaze as well as the body of the one gazing to be exposed through the mechanisms of what Amelia Jones $(2002,936)$ has termed a reciprocal "eternal return" between the seer and the seen, Self and Other. ${ }^{42}$ In the very act of both gazing and performing an object of the gaze, Kamerić intentionally displaces whatever we may think we know about the subject in the photograph. She turns the inquisitive gaze around and directs it at the viewer, who is forced to confront his or her own projections.

There is a certain irony at work in Kamerićs choice of placing the enlarged graffiti over her fixed form, because the "Bosnian girl" depicted by the unknown soldier's contemptible words is shown to be not a girl after all, but rather an image. We shall not understand Kamerić as wishing to present herself as the "Bosnian girl" in an attempt to salvage, through beauty and purity, the tarnished image invoked by the graffiti. This would only result in a one-sided representation. Rather, by juxtaposing the clean and confrontational image of herself with the harmful text, the artist shows that any attempt at a singular definition involves an unequal distribution of power that in this case rests on a sexist and racialized discourse. In her essay in this volume, Anca Parvulescu emphasizes the need for a reconfiguration of the study of race and racism in the European context in order to account for the emergence of "new subalterns" who often come from the European peripheries. Parvulescu urges for more complex configurations of race that are not locked in the

42 Amelia Jones $(2002,936)$ notes that self-portrait photography is a useful tool for dismantling harmful mechanizations of the gaze that serve to normalize and stereotype subjects. Through reiteration, the projection directed toward others' bodies (women, minority groups) is exposed as a lack that the observer attempts to disguise. 
white-black binary and allow for an intricate racial field to emerge that can account for the "multiple hierarchies," "multiple axes," and "complex nodes of racialization" at work in Europe today. If we understand the racial field in Europe as operating according to a hierarchy of precarity, as Parvulescu further suggests, then it becomes clear how the image that the 'Bosnian girl' graffiti sketches is not only a sexist one, but a racialized one as well, as the figure it invokes is precarious to the extreme. From the way the graffiti depicts this 'Bosnian girl,' one might draw several conclusions. First, this person is probably severely dispossessed, hence her 'unclean' appearance. Second, since the graffiti was left by an unidentified Dutch soldier whose troops were stationed near the town of Srebrenica, this person is probably not merely Bosnian, but belongs to the Bosniak/Muslim ethnic group whose number of casualties during the Bosnian war exceeded any other's (as the Srebrenica genocide tragically attests to). Third, the fact that the figure is gendered as a girl (not a woman) increases her state of vulnerability and disturbingly invokes the notion of sexual violence that the female Bosniak population was most subjected to during the war in Bosnia.

"Bosnian Girl," therefore, is far more than a contestation of an unknown soldier's prejudices. As the work attained popularity and was exhibited in public spaces in West Europe, it also questioned broader assumptions about the Yugoslav war and its peoples. As Bosnia, in particular, had been depicted in much media coverage through an excessively violent, destructive, and bleak imagery of the war, Kamerićs usage of her own image, alive and assertive, challenges a straightforward understanding of the "Bosnian girl" and Bosnian people at large. With this work, Kamerić created an image that can be termed transgressive to the extent that it does not reject, but rather embodies a derogatory representation, in line with Irigaray's concept of mimesis. To secure the work's visibility, an advertising campaign was created and posters of the image were distributed widely all over Europe. Additionally, the work was featured in many (West and East European) magazines, it was made into billboard ads, and distributed in the form of postcards.

With her project, Kamerić created a point of entry into a Europe 
that essentially had its doors closed. Ironically, "Bosnian Girl” was able to travel across borders that seemed open and sympathetic to artistic ideas proceeding from a certain place, but remained closed for the people from the same region. The fact that Kamerićs piece was featured in many West European public spaces (through the mentioned distribution of posters, ad campaigns, postcards, and so forth) can be understood as an act of unobstructed border-crossing, something that until very recently represented a nearly impossible undertaking for citizens from Bosnia and Herzegovina, due to the visa regimes that were still in place. While this is arguably the most transgressive aspect of the work (since it involves an actual transition from the European peripheries to its centers), its eventual reach might be limited. As Anikó Imre astutely notes in her contribution to this volume, there is a long history of peripheral intellectuals being granted mobility within Europe and participation in European cosmopolitanism in exchange for being "nationalized," that is, framed as representatives of their national cultures. This way, the hierarchical relation between Europe's East and West is maintained as the peripheral actors always carry the mark of nationality while the center enjoys its hold on an unmediated, universal cosmopolitanism. With this in mind, it becomes important to consider to what extent Kamerićs work not only challenges racialized and nationalist European frames, but actually conforms to a model of Bosnian/Balkan nationality already in place that was readily received by the West in exchange for mobility and visibility. While multiple factors are undoubtedly at play, considering how "Bosnian Girl" is also imbricated in existing hierarchies of mobility complicates a straightforward affirmative reading of this work and lends it, therefore, increased critical significance and urgency.

\section{Performing Gender, Unsettling Borders}

It is necessary to examine the intersection of gender and the nation in order to understand how both implicate each other in produce social realities that allow unrestricted mobility only for certain bodies, Katherine 
Verdery illustrates in 'What was Socialism, and What Comes Next.' (Verdery 1996, 62). Gender is one of the key factors in the unequal distribution of mobility in today's Europe, and the following work presents an intimate engagement with EU gendered policies of inclusion and exclusion. For the long-durational work "Looking for a Husband with EU Passport” (2000-2005), performance artist Tanja Ostojić published an ad of herself on the Internet in which she is shown photographed from the knee up, facing the camera. (See Figure 3) The image is striking in its severity, as the artist is shown completely naked, bald, without any trace of body hair, her gaze empty. Having received over 500 replies from men who were interested in meeting and marrying her, Ostojić would eventually marry a German suitor, an artist himself, who she would divorce in 2005. Not long afterwards, she would organize an official 'divorce party' in order to commemorate their separation.

Offering her passive body for marriage in return for EU citizenship, Ostojićs piece makes use of the fact that, as Helma Lutz (1997, I03) observes, "more than ever, marriage has become the backbone of legal entrance into the EU." This is also echoed in the essay by Brigitte Hipfl in this book, in which she discusses the gendered labor market in Europe that is based on a "mutual exchange of desire" between East European women, who seek a life away from precarity, and West European men, who seek the fantasy of a less emancipated, more traditional woman. Lutz (1997) further argues that it is not through sexual difference, but through the markers of race, ethnicity, and national belonging that differences between the 'European woman' and the 'immigrant woman' are constructed.

Lutz explicitly states that the former Yugoslavia, as well as other former socialist countries, have been largely left outside of the frame of the 'new' Europe, making it clear that 'Europe,' more often than not, is actually built upon the image of the West. In this binary configuration, the 'true' European women are imagined as emancipated and successful individuals who have control over their life. Accordingly, women from the 'outside' are placed somewhere towards the other end of the spectrum, and their lives are often figured as traumatic, oppressed, and 


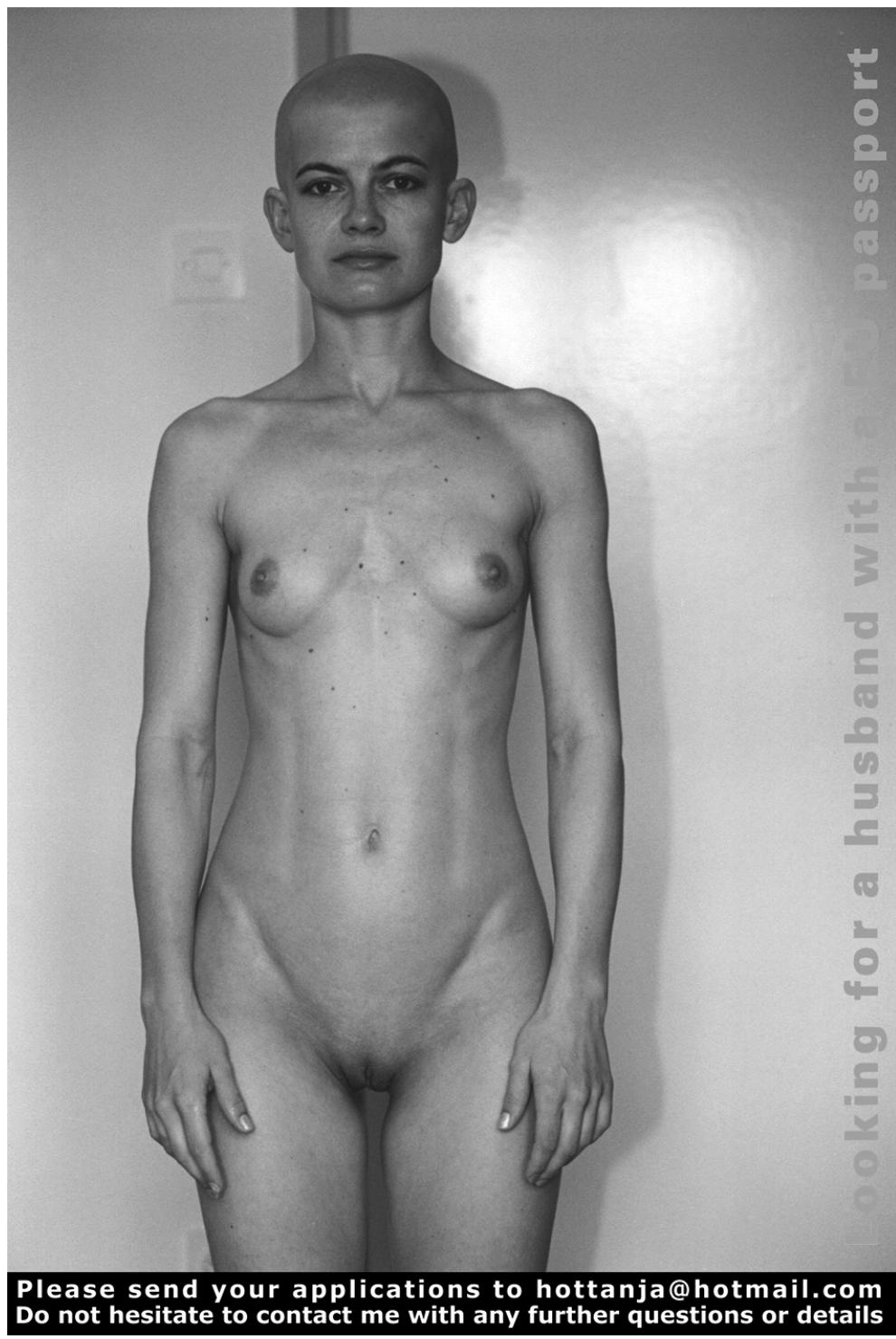

FIgURE 3: Tanja Ostojić, 'Looking for a Husband with EU Passport,' 2000-2005. 
difficult as a direct result of their origins (97). In "Looking for Husband with EU Passport," Tanja Ostojić invokes this very same binary by creating an object of desire out of the EU Passport. It is that which allegedly promises the affluence and good life associated with the European Union, away from oppressive customs and a traumatic history signified by the collapse of Yugoslavia. Since she desires it but does not possess it (yet), Ostojić falls into the category of the immigrant woman who wishes to be granted entry. In an unconvincing (and this is important) effort to 'pass,' it seems that she has already done the necessary work of leaving behind signs of nationality, ethnicity, and even personhood, offering up a 'blank slate,' as it were, ready to be molded according to the stipulations of "national normality" (Balibar 2002, 78) of whichever country grants her access. Since the 'default' image of the oppressed woman is a racialized one, as Lutz points out, Ostojić makes an attempt, in her performance, to have her body represent the exact opposite: hers is a very white, very bare body. Any association with potentially dangerous practices and beliefs are dismissed in Ostojićs performance, as the lack of cover and body hair point to the absence of customs, traditions, and religious and cultural symbols (Pintilie 2007).

Making an appeal to national normality in the European Union, Ostojić has made certain that her body is unthreatening and uncontaminated by foreign customs, so that it might be readily absorbed into the West. As Brigitte Hipfl further points out in her contribution, debates on gendered East-West relations permeate much of the European public debate, with the consequence that East European women are routinely perceived as either victims or cunning schemers. Perhaps Ostojić anticipates the possibility of being read as a manipulator of West European men, and therefore makes sure that her intentions are not obscured, according to a logic of what-you-see-is-what-you-get: she wants an EU passport, and in exchange she offers her body up to a sterile, clinical gaze. But, as Rosi Braidotti (1994, I95) notes, a "body that is open to scrutiny, observation of the biomedical gaze, is in fact a body that fully coincides with its own image, i.e. a corpse." In "Looking for Husband," we are not in fact looking at a person; it is an image at best, a dead body at worst. 
In "Beautiful Dead Bodies: Gender, Migration and Representation in Anti-Trafficking Campaigns” (2007), Rutvica Andrijašević explains that there is a dominant construction of East European nationals, operating along specific gender lines, which posits masculinity according to the image of the 'criminal' and femininity according to the image of the 'victim.' Furthermore, according to Andrijašević, this stereotypical imagery, which is often internalized, eroticizes the image of the woman as victim (24). This same violent imagery is even present in East European anti-trafficking campaigns that the author analyzes, arguing that they put forward, in the name of liberation and protection of women, the stereotypical images which render women's bodies as passive, sexual objects. Focusing on disconnected body parts and often 'hiding' the face of the woman in the picture, the victimized and battered female body becomes an invitation for the spectator to freely project their fetishistic fantasies onto it: "it is a body put on display, a body to be gazed at" (38).

While Ostojićs piece invokes this tradition of East European female victimhood by putting her body on full display, it is important to notice that what actually emerges is a disturbing notion of absence. The artist has gone out of her way to 'remove' anything that might hinder her transition to EU citizenship, including the stigma associated with belonging to the former Yugoslav region. As Dimitar Bechev $(2006,7)$ observes, the war in Yugoslavia "was seen as a mere repetition of earlier cycles of ethnic bloodshed," and with the disintegration of Yugoslavia becoming associated with a loss of political/cultural status, other East European countries sought to disassociate themselves from negative image connected to the Balkans. By addressing the problematic of mobility and immobility, which characterized postwar Yugoslavia, in "Looking for a Husband with EU Passport," Ostojić draws attention to configurations of 'Balkan backwardness' that serve to uphold the distinction between the 'true' Europe and its Others (within). Ostojić's work is striking because she uses her double disadvantage as it were: her status as woman and as Eastern/not-quite-European, in order to deconstruct the assumed normality of the inferior status of both. In order 
to be able to 'pass,' Ostojićs work seems to suggest, a body needs to be seen as unambiguous, unthreatening, and neutral.

If we are unconvinced by the artist's 'effort to pass,' then this is precisely the point. In the process of disassociation, life has been taken out of the picture. Ostojićs body is one that has been stripped of any ideological markers, in order to invoke a sense of neutrality. However, this attempt necessarily fails, as the viewer is left disturbed rather than placated. In "Looking for a Husband," the mimetic occupation of the image that the artist employs succeeds in both awakening and shocking the observer as the female, Balkan, migrant body is driven to extreme forms of hypervisual inertia. The assumed hidden operations of (illegal) migration and trafficking are brought into the public arena and it is these that are opened up for scrutiny, rather than the naked female body. Ostojić uses extremely static imagery in her self-representation in order to point to the faulty mechanisms that keep frozen visions of the kind presented here in place.

Ostojićs politics of parody constitutes a performative intervention into the workings of ideological barriers that uphold, among other things, notions of 'true' Europeanness and its failed Selves - in this case, the people and territory of ex-Yugoslavia. By presenting the viewer with an extreme depiction of the artist's naked body, Ostojić points to the often humiliating and dehumanizing requirements for assimilation into the idea of Europe and its political community, when she observes that, "as the European Union states are sharpening the control over non-citizens, the immigration police... even check the warmth of bed sheets in intermarriages between EU- and non-EU partners" (Ostojić 2006). Ostojić seems to be one step ahead of these mechanisms of interrogation in her performance, as she already provides the viewer with a probing insight into her anatomy. The artist's willingness to have her body exposed in such a public manner attests the commonly hidden workings of the disciplining and controlling of people who seek entry into the EU. By anticipating the inquiring gaze that would impose itself during her attempt at integration, Ostojić takes the power of scrutiny out of the hands of EU law and places it on herself, in an unexpected act 
of resistance. Paradoxically, by overexposing her own body, the artist's parodic interpretation of the EU mechanisms of inclusion/exclusion, surveillance, gazing, and disciplining makes these transparent and held up for scrutiny.

Ostojić dispels with notions of Western emancipation/Eastern backwardness by showcasing that the conditions of successful entry into the EU also hinge on a profoundly gendered, racialized, and heterosexist power unbalance. This hierarchical positioning assumes an East European backwardness of the kind that Rasa Navickaite addresses in her chapter in this volume. As gendered and sexual progress become associated with the West, the East will have to perform these qualities in order to undertake the "return to Europe." Ostojić questions the assumed freedom that the European networks of mobility offer to women by placing her own body at the forefront and showing that even the most 'liberated' spaces, predominantly associated with the West, are always already constructed in ways that categorize women and hinder their possibility of movement (Videkanić 2009). The fact that it remains difficult to pinpoint where the artist as a subject begins and the performance ends (she will indeed marry one of the men replying to her ad, only to divorce him some time later) points to the artist's deep immersion into the political and ideological discourse which produces the limited options for mobility and transition that the art work seeks to dismantle. The outcome of such mimetic practices is not only a crossing of borders, but also a questioning of the very conditions that serve to keep them in place.

\section{Conclusion}

The region of the former Yugoslavia represents, according to Jovana Stokić (2006), "a true blind spot of Europe," in the sense that it is impossible to interpret it according to a reductive dualistic logic of East and West, Self and Other, progressive and backwards. And indeed, I have shown in this chapter how Todorova's concept of Balkanism 
facilitates an understanding of art from this East European periphery as a critical framework in its own right, as Balkanism shifts the traditional Self-Other dichotomy characteristic of colonial and orientalist discourses into a more complicated configuration of 'the other within' or 'the failed Self.'The ambivalence of a position at once inside and outside of Europe, which characterizes the Balkan region, can be understood as a productive starting point for the interrogation of Fortress Europe. This is what provides to the art works that I have engaged with their transgressive force.

Works by ex-Yugoslav artists are characterized by an immersion into normative narratives and ideological frameworks, rather than a distantiation, which makes it possible to interrogate them from within, often by inhabiting a harmful image. Frequently adopting a Balkanist discourse in their works, these artists exaggeratedly perform a stereotype in order to unsettle its accepted meaning and move it towards alternative registers of signification. Therefore, approaching art by ex-Yugoslav artists through a postcolonial theoretical framework, allows for the emergence of a productive meeting point between postsocialist and postcolonial trajectories. According to Rosemarie Buikema (2012, 290), it is "art's dialogicity, materiality and medium specificity that enables artefacts to tentatively perform contested truths and contain intricate complexities, thus functioning as possible constitutors of new and multilayered communities."

Art can have a transgressive potential in its creative engagement with ideological frameworks; however, its reach can be limited. My argument puts forward a synthesis of art and theory that propels criticism of hegemonic structures into new realms of visibility and signification, and specifically urges for the consideration of art from the ex-Yugoslav region, which finds itself at the intersection of postcoloniality and postsocialism, East and West, European and non-European, as key site of resistance to a binary logic which serves to keep Europe's ideological divide in place. 


\section{Works Cited}

- Bakić-Hayden, Milica. "Nesting Orientalisms: The Case of Former Yugoslavia," in Slavic Review, 54(4) (1995): 917-931.

- Balibar, Étienne. "What is a Border?" in Politics and the Other Scene. London: Verso, 2002.

- Bechev, Dimitar. "Constructing South East Europe: The Politics of Regional Identity in the Balkans." RAMSES 2 Working paper. 2006: I-23.

- Bertek, Tihana. "On the Borders of Visibility. From Observer to Participant." Criticize This!, (2013): 29-36.

- Braidotti, Rosi. "Introduction: By Way of Nomadism." In: Nomadic Subjects. Embodiment and Sexual Difference in Contemporary Feminist Theory. New York: Columbia University Press, 20 I r. 2nd Edition.

- Braidotti, Rosi, “Cyberfeminism with a Difference.” I 996. http://www.let. uu.nl/womens_studies/rosi/cyberfem.htm

- Buikema, Rosemarie. "Performing Dialogical Truth and Transitional Justice: The role of Art in the Becoming Post-Apartheid of South Africa," in Memory Studies 5(3) (2012): 282-292.

- Haraway, Donna. "Situated Knowledges: The Science Question in Feminism and the Privilege of Partial Perspective." Feminist Studies 14(3) (I 988): 575-599.

- Imre, Anikó. "Postcolonial Media Studies in Postsocialist Europe." boundary 2 4I(I) (20I4): II 3-I34.

- Irigaray, Luce. Speculum of the Other Woman. Trans. Gillian C. Gill. Ithaca: Cornell University Press, I 985 .

- Jones, Amelia. “The 'Eternal Return': Self Portrait Photography as Technology of Embodiment." Signs: Journal of Women in Culture and Society, $27(4)(2002): 947-978$

- Kamerić, Šejla. Bosnian Girl. 2003. Public project: posters, billboards, magazine ads, postcards. Black-and-white photograph. Dimensions variable. http://sejlakameric.com/works/bosniangirl/

- Kovačević, Nataša. Narrating Post/communism: Colonial Discourse and Europe's Borderline Civilization. London: Routledge, 2008.

- Lutz, Helma. "The Limits of European-ness: Immigrant Women in Fortress Europe.” Feminist Review 57, Citizenship: Pushing the Boundaries, (I 997): 93-III.

- Moore, David Chioni, "Is the Post- in Postcolonial the Post- in Post-Soviet? Toward a Global Postcolonial Critique.” PMLA, Special Topic: Globalizing Literary Studies, I r 6: I (200I): I I I - I 28.

- Muñoz, José Esteban. “The White to be Angry”: Vaginal Creme Davis's Terrorist Drag, in Disidentifications: Queers of Color and the Performance of Politics. Minnesota: University of Minnesota Press, I 999. 
- Ostojić, Tanja. "Looking for a Husband with EU Passport." Long-durational multi-media project. 2000-2005. Brooklyn Museum Feminist Art Base. http:// www.brooklynmuseum.org/eascfa/feminist_art_base/gallery/tanja_ostojic. php? $\mathrm{i}=\mathrm{I} 360$.

— Ostojić, Tanja, "Mission Statement.” N.p, n.d. http://www.van.at/see/tanja/ index.htm.

- Ostojić, Tanja, “Docu \#8: Ostojić/Statement.” Austria Presse Agentur. 4 January 2006. <http://www.van.at/see/tanja/>

- Papenburg, Bettina and Zarzycka, Marta, Eds. Carnal Aesthetics. Transgressive Imagery and Feminist Politics. London/New York: I.B. Tauris, 2013.

- Pettman, Jan Jindy. Worlding Women. A Feminist International Politics. London and New York: Routledge, I 996.

- Pintilie, Ileana. "The Public and the Private Body in Contemporary Romanian Art." Artmargins Online. (2007) http://www.artmargins.com/ index.php/2-articles/I 20-the-public-and-theprivate-body-in-contemporaryromanian-art

- Scott, Krista. "Imagined Bodies, Imagined Communities. Feminism, Nationalism, and Body Metaphors.”The Feminist eZine, I999. <http:// www.feministezine.com/feminist/modern/Imagined-Bodies-ImaginedCommunities.html> [ACCESSED I I DEC 2OI 2]

- Stokić, Jovana. "Un-Doing Monoculture: Women Artists from the "Blind Spot of Europe” — the Former Yugoslavia." Artmargins Online (2006). http:// www.artmargins.com/index.php/archive/532-un-doing-monoculture-women-artists-fromthe-blind-spot-of-europe-the-former-yugoslavia.

- Stošić, Slobodan. "Proposal for land art Project." onaj drugi, 05-I I-20 I 2, http://slobodanstosic.tumblr.com/post/3504I I 46898.

- Todorova, Maria, Imagining the Balkans. New York: Oxford University Press, 2009. 2nd Edition.

- Veličković, Vedrana, "Belated alliances? Tracing the intersections between postcolonialism and postcommunism." Journal of Postcolonial Writing, 48:2 (20I2): I64-I75.

- Vedery, Katherine. What Was Socialism and What Comes Next? Princeton: Princeton UP, 1996.

- Videkanić, Bojana. "Tanja Ostojićs Aesthetics of Affect and Postidentity (Series "New Critical Approaches) Article." Artmargins Online. (2009) http://www.artmargins.com/index.php/2-articles/4I 4-tanja-ostojisaesthetics-of-affect-andpostidentity-series-qnew-critical-approachesq. 

Part III

Afterword 


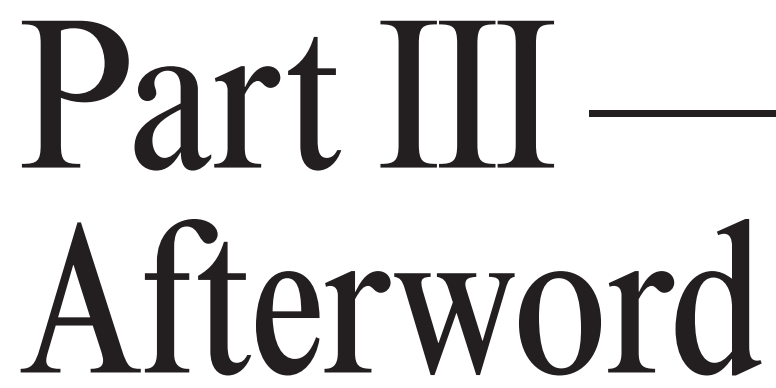

\section{On Narration, Belonging and Unhoming}

Under the heading of Europe, I have discussed in this dissertation questions of belonging, spatiality, nationhood and bordering in their personal, political and analytical dimensions. I am drawn to the question of Europe because I know its contradictions; its promise of unity, diversity and mobility and its historical myopia, border logic, internal divisions and hierarchies, silences and exclusions. I live in these contradictions; they shape my understanding of Europe, and so I find myself nodding along with Braidotti (20II, 3I) when she observes:

'European' is intimately linked for me to issues such as borders and borderlands, cultural mixity and inter-cultural conflicts. 'European' stands for physical mobility through endless waves of migration which are seldom taken into account in the national narratives of European states. 'European' also refers to a special brand of historical political memory which, however aware it may be of colonialism, cannot easily share the claims of a post-colonial condition; nor can it easily shake off the legacy of fascism.

These phenomena are constitutive of how Europe — as an idea, a place, a discourse a myth — comes into being. As these processes are frequently 
obscured, I have highlighted the importance of being attentive to some discourses and phenomena that continue to shape Europe - historical erasure, the notion of the cultural Other and the East/West divide - to inquire after and interrogate the meaning of Europe today. While the question of Europe is not new, it is "one that needs to be asked again and always anew for each 'today'." (Kaiser \& Thiele 20I6, 274) The narrative that has emerged here is an open-ended answer to that question, an alternative and mobile cartography of Europe.

I have headlined this dissertation with two autobiographical vignettes that both, at first glance, seem to be about absence and emptiness; the memory of the geography lesson during which the former Yugoslavia was erased from the map of Europe, and the disorienting realization of my status as a refugee, which is experienced as being nowhere. Both instances were conceptualized as non-exhaustive but critical entry points into the interrogation of the meaning (and the myth) of Europe today. Throughout this research, it has been my intent to show how these liminal entities and peripheral actors in the European play a central role in the configuration of Europe, even if they are frequently (but never successfully) placed at the limits or the outside of this discursive regime. As such, they function as salient figurations for an alternative conceptualization of Europe.

There is a reason why these memories came back to me and demanded to be narrated. Perhaps the most central insight that I have gained through the process of conducting this research is that there is no such thing as purely personal, individualized experience. This does not mean that there are no unique experiences, of course, but rather that personal experience is mediated by institutional processes, which in turn inform and are informed by symbolic registers of meaning. This insight has been invaluable for two reasons. First, it has allowed me to work under an elaborate analytical scope, one that could encompass the study of individual, structural and representational material without diluting the argument, namely that Europe should be understood as a discursive regime than enacts material effects which can be contested and interrogated through specific border figurations. Secondly, and 
most precious to me, it has allowed me to place my experiences, that at the time when they happened I experienced as absence, akin to being taken off the map, in a larger narrative configuration together with my analyses, creating a dialogic exchange between them. The initial lack I had experienced is transformed into excess, an abundance that cannot be encompassed by customary containers of meaning and prompts other mappings, which have featured in this dissertation.

The emphasis on the narrative aspect of the argument that has unfolded here should thus be seen as supplementary to the analysis. Behind and before the analysis, there is the impetus to say something (different), to tell a story. The story of Europe that emerges here is a story about mobility, migration and belonging. Such trajectories seem to lend themselves organically for the narrative format; as the BosnianAmerican writer Aleksandar Hemon declares: "Movement through space, literally and figuratively, generates stories - migration equals narration squared." (2019, I29) Though narrative is meaningful unto itself, it also performs a function. This is evident in the field of migrant and postcolonial literature; examining the work of Emine Sevgi Özdamar, Angelika Bammer notes how the former's writing is able to re-conceptualize the notion of displacement through which the refugee-migrant is usually understood, so that "the migrant subject appears not doubly absent (neither here nor there), but multiply present (both from elsewhere and now here)." (2005, I53) This is an important insight, because it demands a shift in perspective. What if the absence I experienced at the time of the geography lesson on Europe, with the blotted out former Yugoslav space, becomes reconfigured as multiple presence? What if my feeling of being 'nowhere' as a result of my unwilling identification with the word 'refugee' can be understood belonging to and inhabiting multiple 'somewheres' at the same time instead? And what if these questions were mirrored back to the context in which the original sense of absence emerged? What configuration of Europe cannot hold these multiple somewheres at the same time — and might we imagine one that could? 
My questions emerge out of what Homi Bhabha has called the "spirit of the 'right to narrate" belonging to the mobile/immigrant/ migrating subject; this outlook "demands that we revise our sense of symbolic citizenship, our myths of belonging" as well as insists on "the importance of historical and cultural re-visioning." (Bhabha I994, xx) Existing at and within the borders of multiple spaces, communities and histories (which does not equal being nowhere) demands articulation, which creates an imperative to interrogate the discourses that cannot hold such abundance. Gloria Anzaldúa's conceptualization being a border subject resonates here:

Living on borders and in margins, keeping intact one's shifting and multiple identity and integrity, is like trying to swim in a new element, an "alien" element. There is an exhilaration in being a participant the further evolution of humankind, in being "worked" on. I have the sense that certain "faculties" - not just in me but in every border resident, colored or non-colored - and dormant areas of consciousness are being activated, awakened. Strange, huh? And yes, the "alien" element has become familiar - never comfortable, not with society's clamor to uphold the old, to rejoin the flock to go with the herd. No, not comfortable but home. (I987, preface)

Anzaldúa imagines the border resident as someone who feels at home in the space of multiple and fragmented belonging. Feeling at home, paradoxically, consists precisely of being what Bhabha (I994, I3) called being "unhomed," not fixed in a single location, inhabiting simultaneously multiple contexts. Being unhomed should not be confused with homelessness, as the former "is the condition of extra-territorial and cross-cultural initiations." (ibid.) These conditions cannot be contained by the canonical narratives, and thus require another vernacular, as well as the proliferation of different stories, displacing the singularity of 'home' and other collectivities - the nation, Europe. In these accounts, a poetics of home (Buikema 2005) is developed, which subjects 
the question of belonging to constant interrogation. Out of this enterprise emerges not one story (myth) but an abundance of narratives. Rosemarie Buikema notes that " $\mathrm{t}]$ he concepts of home and identity are [...] strongly related to discursive space, to the possibility and ability to share experiences through storytelling." $(2005, \mathrm{I} 78)$ Home and story therefore exist in a symbiosis; if a singular notion of home is discarded, the stories we can tell about home become multiplied and multidirectional, so that it becomes possible to exist in numerous locations at the same time.

These ruminations on the possibility and the necessity of reconfiguring the notion of home are in line with the larger project of this dissertation, which similarly asked how Europe, the nation and belonging are constructed, and how they may be imagined differently. Rather than proposing answers, the value of this approach lies in the questioning, and in that questioning, the rethinking, of supposedly fixed categories. Border figurations and border subjects are, as I have proposed, integral vantage points from which to examine taken-for-granted meanings about home, belonging and the historical canon. The condition of being uprooted, unhomed, or a mobile subject is, as Merolla and Ponzanesi note,

...therefore an imperative, an injunction against the reproduction of hegemonic discourses, but also a way of keeping that double insight, that sharpness of critical experience that is based on the tingling feeling of unbelonging, of yet but not quite, of comforting un-homeliness. $(2005,5)$

This critical conceptualization is based in actual experience, and thus thinking through the lens of the mobile subject is not a philosophical abstraction, but an attempt to ground world building from the condition of displacement and peripherality, which may allow for more alternative and less hegemonic understandings of belonging. This is therefore a theoretical configuration with a political impetus that is grounded in experience, which has been the guiding principle of my 
research. Moreover, there can be comfort in unhoming, the feeling of never fully belonging being, paradoxically, the closest thing to 'home' in the traditional sense. Unhoming is both poetics and politics, an imperative for the current political moment in Europe with pronounced xenophobia, racisms, territorial politics and nationalism on the rise. As an alternative way of conceptualizing Europe, Aparna et al. propose the condition of 'being lost:'

...we argue that especially in the case of refugee and migrant flows in/to Europe we must seriously re-evaluate the existential condition of «being lost», considered here less as a negative and potentially dangerous attribute and more as a chance to see the entirety of Europe from a critical corner, an angle, a margin, a border (Aparna et al., 2or6). The condition of «being lost» then serves as a standpoint epistemology (Haraway, I988) from where we problematize imaginaries that fix Europe within racialised and normative imaginaries of nation-states and national identities. $(2017,463)$

'Being lost' here is another way of understanding the condition of unhoming. Instead of homelessness, this condition consists of being a border(ed) subject whose multiple belongings insist on being articulated, not just as a narrative, but as a politics. The authors go on to say that

Such a politics is built on the rhythms and temporalities that emerge from being and inhabiting, rather than speaking merely of, borders (Aparna et al., 2or6), therefore being able to see Europe in its entirety, outside-in, and from a critical vantage point, and subsequently doing Other Europes because of the same. (2017, 449)

The account(s) of Europe that are present in this dissertation are precisely those that come out the condition of inhabiting borders, which necessitates narration. This particular narrative of Europe however is 
not, and could not be, organized and 'whole' - it is not a myth. As it zigzags through different contexts, modalities and experiences that nevertheless hold together by echoing a number of border dwellings in the European context, the narrative prompts the probing into and the opening up of containers of meaning and asks how they may be reconfigured so as to encompass the condition of unhoming that demands 'the right to narrate' of multiple somewheres. 
Works cited

- Aparna, K., Mahamed, Z., Deenen, I., Kramsch, O. 20 I 7. "Lost Europe(s).” Special Issue: Rethinking Europe through an Ethnography of its borderlands. Journal of Ethnography and Qualitative Research, 3, 435-45 2.

- Anzaldúa, Gloria. I 987. Borderlands/La frontera. The New Mestiza. San Francisco, Aunt Lute Books.

- Bammer, Angelika. 2005. “"Between Foreign and Floating Signs”: The Language of Migrant Subjects." Migrant Cartographies. New Cultural and Literary Spaces in Post-Colonial Europe, eds. Ponzanesi, Sandra \& Merolla, Daniela. Lexington Books, Lanham, I 5 I- I65.

- Bhabha, Homi K. I 996. The Location of Culture. New York: Routledge.

- Braidotti, Rosi. 2o I r. Nomadic Subjects. Embodiment and Sexual Difference in Contemporary Feminist Theory, 2nd edition, New York: Columbia University Press.

- Buikema, Rosemarie. 2005. "A Poetics of Home. On narrative voice and the deconstruction of home in migrant literature." Migrant Cartographies. New Cultural and Literary Spaces in Post-Colonial Europe, eds. Ponzanesi, Sandra \& Merolla, Daniela. Lexington Books, Lanham, I77- I89.

- Hemon, Aleksandar. 2or 9. My Parents: An Introduction. New York: MCD.

- Kaiser, Birgit \& Thiele, Kathrin. 2or 6. "Other Headings." Interventions, I 8:2, $270-285$.

- Merolla, Daniela \& Ponzanesi, Sandra. 2005. "Introduction." Migrant Cartographies. New Cultural and Literary Spaces in Post-Colonial Europe, eds. Ponzanesi, Sandra \& Merolla, Daniela. Lexington Books, Lanham, I-52. 


\section{CURRICULUM VITAE}

Milica Trakilović was born in Tuzla, Bosnia and Herzegovina (at the time still part of Yugoslavia) on October Io, I986. In 2009, she obtained her bachelor's degree in English Lanugage and Literature from the Faculty of Philosophy at Tuzla University in Tuzla, Bosnia and Herzegovina. In 2013, she graduated cum laude from the research master program in Gender \& Ethnicity, Utrecht University, the Netherlands. She started teaching in the Graduate Gender Programme at Utrecht University in 2013. From 2015 until 2018, she worked as a Research Assistant in the ERC funded project Bodies Across Borders: Oral and Visual Memory in Europe and Beyond (BABE), based at the Department of History and Civilization at the European University Institute in Florence, Italy, and headed by cultural historian Luisa Passerini. In 201 5, she started her $\mathrm{PhD}$ trajectory at the Institute for Cultural Inquiry at Utrecht University under the supervision of Prof. dr. Rosemarie Buikema and Prof. dr. Sandra Ponzanesi. During her PhD, she has published on the topics of migration symbolic and institutional bordering processes in Europe and their related representational and discursive practices. In 2018 , she co-organized the 26th edition of the NOISE summer school at Utrecht University on the topic of Social and Political Suffocations. She is currently co-editing the volume The Mobility of Memory Across European Borders and Beyond (Berghahn Books). Milica still works in the Graduate Gender Programme at Utrecht University in a lecturing and supervisory capacity. 
(C) 2020, MILICA TRAKILOVIĆ 

